Prepared in cooperation with the

Naval Facilities Engineering Command

\title{
Simulation of Zones of Groundwater Contribution to Wells at site GM-38, Naval Weapons Industrial Reserve Plant, Bethpage, New York
}

Scientific Investigations Report 2014-5036 



\section{Simulation of Zones of Ground water Contribution to Wells at Site GM-38, Naval Weapons Industrial Reserve Plant, Bethpage, New York}

By Paul Misut

Prepared in cooperation with the Naval Facilities Engineering Command

Scientific Investigations Report 2014-5036 


\title{
U.S. Department of the Interior SALLY JEWELL, Secretary
}

\section{U.S. Geological Survey Suzette M. Kimball, Acting Director}

\author{
U.S. Geological Survey, Reston, Virginia: 2014
}

For more information on the USGS - the Federal source for science about the Earth, its natural and living resources, natural hazards, and the environment, visit http://www.usgs.gov or call 1-888-ASK-USGS.

For an overview of USGS information products, including maps, imagery, and publications, visit http://www.usgs.gov/pubprod

To order this and other USGS information products, visit http://store.usgs.gov

Any use of trade, firm, or product names is for descriptive purposes only and does not imply endorsement by the U.S. Government.

Although this information product, for the most part, is in the public domain, it also may contain copyrighted materials as noted in the text. Permission to reproduce copyrighted items must be secured from the copyright owner.

Suggested citation:

Misut, P.E., 2014, Simulation of zones of contribution to wells at site GM-38, Naval Weapons Industrial Reserve Plant, Bethpage, New York: U.S. Geological Survey Scientific Investigations Report 2014-5036, 58 p.,

http://dx.doi.org/10.3133/sir20145036

ISSN 2328-0328 (online) 


\section{Contents}

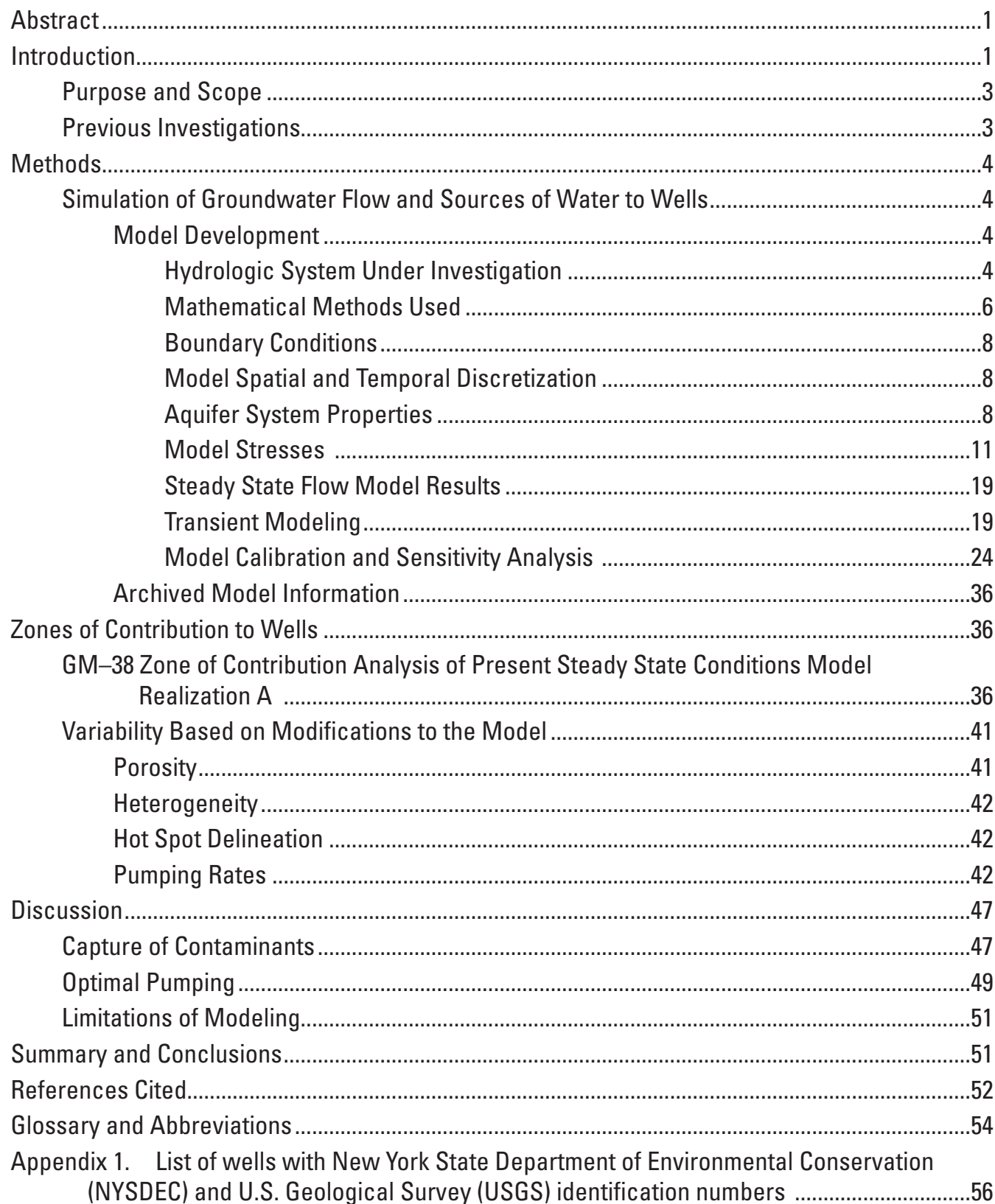

\section{Figures}

1. Map showing generalized groundwater-flow direction, production wells, recharge basins, mapped volatile organic compound plumes adjacent to the Naval Weapons Industrial Reserve Plant (NWIRP), and other local features, Bethpage, New York.........2

2. Map showing aquifer within which water table is present and location of boreholes of hydrogeologic section $A-A^{\prime}$, Bethpage, New York ……........................................

3. Cross section showing section $A-A^{\prime}$ through $G M-38$ area showing hydrogeologic units and borehole intervals of fine-grained sediments, Bethpage, New York 
4. Map showing thickness of Raritan confining unit, boreholes drilled to depths greater than 700 feet below the North American Vertical Datum of 1988, location of section A-A', and other local features, Bethpage, New York.

5. Map showing specified production wells, model drain cells, creeks, stream-gaging stations, model constant head cells, water-level contours, no-flow model boundaries, and other local features, Bethpage, New York

6. Map showing outer region of MODFLOW model grid showing row and column numbers, the GM-38 Hot Spot (from ARCADIS, 2009), the location of section A-A', and other local features, Bethpage, New York.

7. Section showing distribution of coarse-grained, fine-grained, and interbedded facies identified in borings and wells along part of section $A-A^{\prime}$ (designated as A1-A2) that are used as hard data in conditional simulation of Magothy aquifer heterogeneity, Bethpage, New York

8. Map showing conditional simulation subgrid showing GM-38 Hot Spot (from ARCADIS, 2009), boring and wells along part of section $A-A^{\prime}$, and other local features, Bethpage, New York.

9. Graphs showing probability of transitioning between facies of the Magothy aquifer at vertical lag distances from 2 to 30 feet, Bethpage, New York

10. Section showing conditional realization $A$ of Magothy aquifer heterogeneity along part of cross section $A-A^{\prime}$...

11. Block diagram showing conditional realization $A$ within regional flow model with boundary conditions, model grid along row 80 , and other local features, Bethpage, New York

12. Block diagrams showing Magothy aquifer heterogeneity realizations $A, B$, and $C$ showing local features and hydraulic conductivity values, Bethpage, New York

13. Map showing specified present steady state conditions (2004-7) pumpage within regional model and GM-38 area (inset), and other local features, Bethpage, New York.

14. Map showing locations of recharge basins and other local features in the regional model and the GM-38 area (inset), Bethpage, New York.....

15. Map showing specified cell-by-cell recharge rates and other local features in the regional model and the GM-38 area (inset), Bethpage, New York .21

16. Map showing simulated present conditions steady state heads at model layer 30 (screen zone of GM-38-RW1) and other local features in regional model and GM-38 area (inset), Bethpage, New York

17. Cross section showing simulated present conditions steady state heads at model row 176 and column 107 (screen zone of GM-38-RW1), Bethpage, New York.

18. Graph showing modeled history of pumpage rates during aquifer test, March to April 2013, Bethpage, New York

19. Map showing observation wells monitored for regional model or GM-38 area and other local features in regional model and GM-38 area (inset), Bethpage, New York ..26

20. Graph showing head time series of U.S. Geological Survey well N1259 from 1961 to 2013 and present-conditions steady state present average, Bethpage, New York ........27

21. Graph showing baseflow (contribution of groundwater to streamflow) as a percentage of total flow, Massapequa and Bellmore Creeks, New York

22. Graphs showing $A$, water level target residuals corresponding to present steady state model simulation Magothy aquifer heterogeneity realization $\mathrm{A}$, and $B$, composite scaled sensitivities corresponding to UCODE_2005 estimation of present steady state conditions MODFLOW parameters, Bethpage, New York 
23. Graphs showing A, simulated transient-state water-level response of GM-38-RW1 MW1 associated with Magothy aquifer realizations $A, B$, and $C$, and history of pumpage rates, March to April 2013, and $B$, response differences between realization $A$ and $B$ and realization $A$ and $C$, Bethpage, New York.

24. Graph showing simulated transient-state water-level response of GM-38-D1 associated with Magothy aquifer realizations $A, B$, and $C$, and history of pumpage rates, March to April 2013, Bethpage, New York

25. Graph showing simulated transient-state water-level response of GM-38-D2 associated with Magothy aquifer realizations $A, B$, and $C$, and history of pumpage rates, March to April 2013, Bethpage, New York

26. Graph showing transient state water-level response of GM-38-D2 associated with baseline simulation of Magothy aquifer heterogeneity realization $A$, alternative simulation of homogeneous Magothy aquifer hydraulic conductivity, and alternative simulation of Magothy aquifer heterogeneity realization A with greater contrast of hydraulic conductivity, and history of pumpage rates, March to April 2013, Bethpage, New York.

27. Map showing zones of contribution represented as projections of maximum extent of three-dimensional particle pathlines tracked backward from pumping stresses at GM-38-RW1 and GM-38-RW3 after 90 days, 1 year, and 2 years, simulated using present steady state conditions model realization A, Bethpage, New York...

28. Diagram of plan view, rotated east-west section of model row 170 , and rotated north-south section of column 80 , showing starting particle locations coincident with GM-38 Hot Spot solid (ARCADIS, 2009) and Magothy aquifer realization A, Bethpage,New York...

29. Plan view of projected pathlines captured by GM-38-RW wells and backward tracked using a present steady state conditions model and Magothy aquifer heterogeneity realization A, Bethpage, New York.

30. Schematics showing travel time and pathlines of forward-tracked particles started at the total GM-38 Hot Spot solid during present steady state conditions and Magothy aquifer heterogeneity realizations $A, B$, and $C$, model grid, southern extent of heterogeneity realization subgrid, and locations of particle discharge, Bethpage, New York

31. Schematics showing travel time and pathlines of forward-tracked particles started at the inner GM-38 Hot Spot solid during present steady state conditions and Magothy aquifer heterogeneity realizations A, B, and C, model grid, and locations of particle discharge, Bethpage, New York...

32. Schematics showing travel time and pathlines of forward-tracked particles started at alternate total GM-38 Hot Spot solid during present steady state conditions and Magothy aquifer heterogeneity realizations $A, B$, and C, model grid, southern extent of heterogeneity realization subgrid, and locations of particle discharge, Bethpage, New York

33. Schematics showing travel time and pathlines of forward-tracked particles started at alternate GM-38 Hot Spot inner solid during present steady state conditions and Magothy aquifer heterogeneity realizations $A, B$, and C, model grid, and locations of particle discharge, Bethpage, New York

34. Plan view of projected pathlines captured by GM-38-RW wells and backward tracked using steady state hypothetical scenario 1 model and Magothy aquifer heterogeneity realizations $A$ and C, Bethpage, New York.

35. Plan view of projected pathlines captured by GM-38-RW wells and backward tracked using steady state hypothetical scenarios 2 and 3, and Magothy aquifer heterogeneity realization $A$, Bethpage, New York. 


\section{Tables}

1. Characteristics of hydrogeologic units, Bethpage, New York

2. Difference in pumping rates between ARCADIS (2010) and U.S. Geological Survey present steady state conditions models for selected wells at site GM-38, Bethpage, New York

3. Water balance simulated by U.S. Geological Survey present steady state conditions model of Bethpage, New York

4. Pumping of wells during transient stress periods, Bethpage, New York..........................25

5. Observation wells monitored for the GM-38 capture zone study, Bethpage, New York

6. Initial and final calibrated parameter values of a MODFLOW present steady state conditions model, as estimated by UCODE_2005, for site GM-38, Bethpage, New York.

7. Simulated minus observed residuals of calibrated present steady state conditions model realization A for site GM-38, Bethpage, New York.

8. Comparison of backward-tracked particle starting points at GM-38 well screens with model layers and GM-38 Hot Spot solids, Bethpage, New York

9. Summary of particle backtracking analysis of GM-38 wells, present steady state conditions, Bethpage, New York.

10. Percentage of capture of forward tracked particles started within the GM-38 Hot Spot inner solid and outer solid rings (ARCADIS, 2009) simulated by a present steady state model and Magothy aquifer heterogeneity realization A, Bethpage, New York

11. Comparison of average travel time of particles in days, baseline and alternate porosity, simulated by a present steady state model for site GM-38, Bethpage, New York

12. Analysis of particle backward-tracking terminations at the GM-38 Hot Spot inner sold and outer solid rings, under three hypothetical pumping scenarios and two Magothy aquifer heterogeneity realizations ( $A$ and $C)$, Bethpage, New York. 


\section{Conversion Factors and Datum}

\begin{tabular}{|c|c|c|}
\hline Multiply & By & To obtain \\
\hline \multicolumn{3}{|c|}{ Length } \\
\hline foot $(\mathrm{ft})$ & 0.3048 & meter $(\mathrm{m})$ \\
\hline mile (mi) & 1.609 & kilometer (km) \\
\hline \multicolumn{3}{|c|}{ Area } \\
\hline square foot $\left(\mathrm{ft}^{2}\right)$ & 929.0 & square centimeter $\left(\mathrm{cm}^{2}\right)$ \\
\hline square foot $\left(\mathrm{ft}^{2}\right)$ & 0.09290 & square meter $\left(\mathrm{m}^{2}\right)$ \\
\hline square mile $\left(\mathrm{mi}^{2}\right)$ & 259.0 & hectare (ha) \\
\hline square mile $\left(\mathrm{mi}^{2}\right)$ & 2.590 & square kilometer $\left(\mathrm{km}^{2}\right)$ \\
\hline \multicolumn{3}{|c|}{ Volume } \\
\hline gallon (gal) & 3.785 & liter (L) \\
\hline gallon (gal) & 0.003785 & cubic meter $\left(\mathrm{m}^{3}\right)$ \\
\hline gallon (gal) & 3.785 & cubic decimeter $\left(\mathrm{dm}^{3}\right)$ \\
\hline million gallons (Mgal) & 3,785 & cubic meter $\left(\mathrm{m}^{3}\right)$ \\
\hline cubic foot $\left(\mathrm{ft}^{3}\right)$ & 28.32 & cubic decimeter $\left(\mathrm{dm}^{3}\right)$ \\
\hline cubic foot $\left(\mathrm{ft}^{3}\right)$ & 0.02832 & cubic meter $\left(\mathrm{m}^{3}\right)$ \\
\hline \multicolumn{3}{|c|}{ Flow rate } \\
\hline foot per day (ft/d) & 0.3048 & meter per day $(\mathrm{m} / \mathrm{d})$ \\
\hline foot per year (ft/yr) & 0.3048 & meter per year (m/yr) \\
\hline cubic foot per second $\left(\mathrm{ft}^{3} / \mathrm{s}\right)$ & 0.02832 & cubic meter per second $\left(\mathrm{m}^{3} / \mathrm{s}\right)$ \\
\hline cubic foot per day $\left(\mathrm{ft}^{3} / \mathrm{d}\right)$ & 0.02832 & cubic meter per day $\left(\mathrm{m}^{3} / \mathrm{d}\right)$ \\
\hline gallon per minute (gal/min) & 0.06309 & liter per second (L/s) \\
\hline gallon per day (gal/d) & 0.003785 & cubic meter per day $\left(\mathrm{m}^{3} / \mathrm{d}\right)$ \\
\hline million gallons per day (Mgal/d) & 0.04381 & cubic meter per second $\left(\mathrm{m}^{3} / \mathrm{s}\right)$ \\
\hline inch per year (in/yr) & 25.4 & millimeter per year (mm/yr) \\
\hline \multicolumn{3}{|c|}{ Specific capacity } \\
\hline $\begin{array}{l}\text { gallon per minute per foot } \\
[(\mathrm{gal} / \mathrm{min}) / \mathrm{ft})]\end{array}$ & 0.2070 & $\begin{array}{l}\text { liter per second per meter } \\
{[(\mathrm{L} / \mathrm{s}) / \mathrm{m}]}\end{array}$ \\
\hline \multicolumn{3}{|c|}{$[(\mathrm{gal} / \mathrm{min}) / \mathrm{ft})]$} \\
\hline foot per day (ft/d) & 0.3048 & meter per day $(\mathrm{m} / \mathrm{d})$ \\
\hline \multicolumn{3}{|c|}{ Hydraulic gradient } \\
\hline foot per mile (ft/mi) & 0.1894 & meter per kilometer $(\mathrm{m} / \mathrm{km})$ \\
\hline \multicolumn{3}{|c|}{ Transmissivity* $^{*}$} \\
\hline foot squared per day $\left(\mathrm{ft}^{2} / \mathrm{d}\right)$ & 0.09290 & meter squared per day $\left(\mathrm{m}^{2} / \mathrm{d}\right)$ \\
\hline
\end{tabular}

Temperature in degrees Fahrenheit $\left({ }^{\circ} \mathrm{F}\right)$ may be converted to degrees Celsius $\left({ }^{\circ} \mathrm{C}\right)$ as follows:

$$
{ }^{\circ} \mathrm{C}=\left({ }^{\circ} \mathrm{F}-32\right) / 1.8
$$

Temperature in degrees Celsius $\left({ }^{\circ} \mathrm{C}\right)$ may be converted to degrees Fahrenheit $\left({ }^{\circ} \mathrm{F}\right)$ as follows:

$$
{ }^{\circ} \mathrm{F}=\left(1.8 \times^{\circ} \mathrm{C}\right)+32
$$

Vertical coordinate information is referenced to the National Geodetic Vertical Datum of 1929 (NGVD29) or the North American Vertical Datum of 1988 (NAVD 88), referred to in this report as "sea level." 
Horizontal coordinate information is referenced to the North American Datum of 1983 (NAD 83).

Altitude, as used in this report, refers to distance above the vertical datum.

*Transmissivity: The standard unit for transmissivity is cubic foot per day per square foot times foot of aquifer thickness [(ft $\left.\left.\mathrm{ft}^{3} \mathrm{~d}\right) / \mathrm{ft}^{2}\right] \mathrm{ft}$. In this report, the mathematically reduced form, foot squared per day $\left(\mathrm{ft}^{2} / \mathrm{d}\right)$, is used for convenience.

Concentrations of chemical constituents in water are given in parts per billion (ppb).

\section{Abbreviations}

$\begin{array}{ll}\text { BWD } & \text { Bethpage Water District } \\ \text { CSS } & \text { Composite scaled sensitivity } \\ \text { IRM } & \text { interim remedial measure } \\ \text { NCDH } & \text { Nassau County Department of Health } \\ \text { NYSDEC } & \text { New York State Department of Environmental Conservation } \\ \text { NWIRP } & \text { Naval Weapons Industrial Reserve Plant } \\ \text { ONCT } & \text { onsite containment system } \\ \text { SPDES } & \text { State Pollutant Discharge Elimination System } \\ \text { TCE } & \text { tetrachloroethylene } \\ \text { TVOC } & \text { total volatile organic compounds } \\ \text { USGS } & \text { U.S. Geological Survey } \\ \text { VOC } & \text { volatile organic compounds } \\ \text { ZOC } & \text { zones of contribution }\end{array}$




\title{
Simulation of Groundwater Zones of Contribution to Wells at Site GM-38, Naval Weapons Industrial Reserve Plant, Bethpage, New York
}

\author{
By Paul E. Misut
}

\section{Abstract}

A three-dimensional groundwater-flow model is coupled with the particle-tracking program ${ }^{1}$ MODPATH to delineate zones of contribution to wells pumping from the Magothy aquifer and supplying water to a chlorinated volatile organic compound removal plant at site GM-38, Naval Weapons Industrial Reserve Plant, Bethpage, New York. By use of driller's logs, a transitional probability approach generated three alternative realizations of heterogeneity within the Magothy aquifer to assess uncertainty in model representation. Finer-grained sediments with low hydraulic conductivity were realized as laterally discontinuous, thickening towards the south, and comprising about 17 percent of the total aquifer volume.

Particle-tracking evaluations of a steady state present conditions model with alternative heterogeneity realizations were used to develop zones of contribution of remedial pumping wells. Because of heterogeneity and high rates of advection within the coarse-grained sediments, transport by dispersion and (or) diffusion was assumed to be negligible. Resulting zones of contribution of existing remedial wells are complex shapes, influenced by heterogeneity of each realization and other nearby hydrologic stresses. The use of two particle tracking techniques helped identify zones of contribution to wells. Backtracking techniques and observations of points of intersection of backward-tracked particles at shells of the GM-38 Hot Spot, as defined by surfaces of equal total volatile organic compound concentration, identified the source of water within the GM-38 Hot Spot to simulated wells. Forward-tracking techniques identified the fate of water within the GM-38 Hot Spot, including well capture and discharge to model constant head and drain boundaries. The percentage of backwardtracked particles, started at GM-38 wells that were sourced from within the Hot Spot, varied from 72.0 to 98.2, depending on the Hot Spot delineation used (present steady state model and Magothy aquifer heterogeneity realization A). The percentage of forward-tracked particles that were captured

\footnotetext{
${ }^{1}$ Glossary terms and acronyms in bold are defined in the glossary on p. 54.
}

by GM-38 wells varied from 81.1 to 94.6 , depending on the Hot Spot delineation used, with the remainder primarily captured by Bethpage Water District Plant 4 production wells (present steady state model and Magothy aquifer heterogeneity realization A). Less than 1 percent of forwardtracked particles ultimately discharge at model constant head and drain boundaries. The differences between forward- and backward-tracked particle percentage ranges are due to some forward-tracked particles not being captured by GM-38 wells, and some backward-tracked particles not intersecting specific regions of the Hot Spot.

During 2013, an aquifer test generated detailed time series of well pumping rates and corresponding water-level responses were recorded at numerous locations. These data were used to verify the present conditions steady state model and demonstrate the sensitivity of model results to transientstate changes.

\section{Introduction}

Several plumes of dissolved volatile organic compounds (VOCs), including tetrachloroethylene (TCE), were identified in a semiconfined aquifer near the Naval Weapons Industrial Reserve Plant (NWIRP) at Bethpage, New York (fig. 1) (ARCADIS, 2009). The plumes were divided into operable units (OU): (a) OU2 to the south and west of the NWIRP, and (b) OU3 to the south and east of NWIRP, apparently originating at a community park. In 2003, the Navy issued a record of decision for OU2, which presently consists of plume remnants to the south and west of the NWIRP (U.S. Navy, 2003). By 2009, the OU2 plume included two areas with total volatile organic compounds (TVOC) greater than 500 parts per billion (ppb) that were likely split by the operation of an onsite containment system (ONCT). Since 1950, the downgradient edge of the OU2 plume has been estimated to travel about 285 feet per year $(\mathrm{ft} / \mathrm{yr}$ ) on average (Naval Facilities Engineering Command, 2011). When the New York State Department of Environmental Conservation (NYSDEC) issued a record of decision for OU3 in 2013, a pump-and-treat interim remedial measure (IRM) was in 


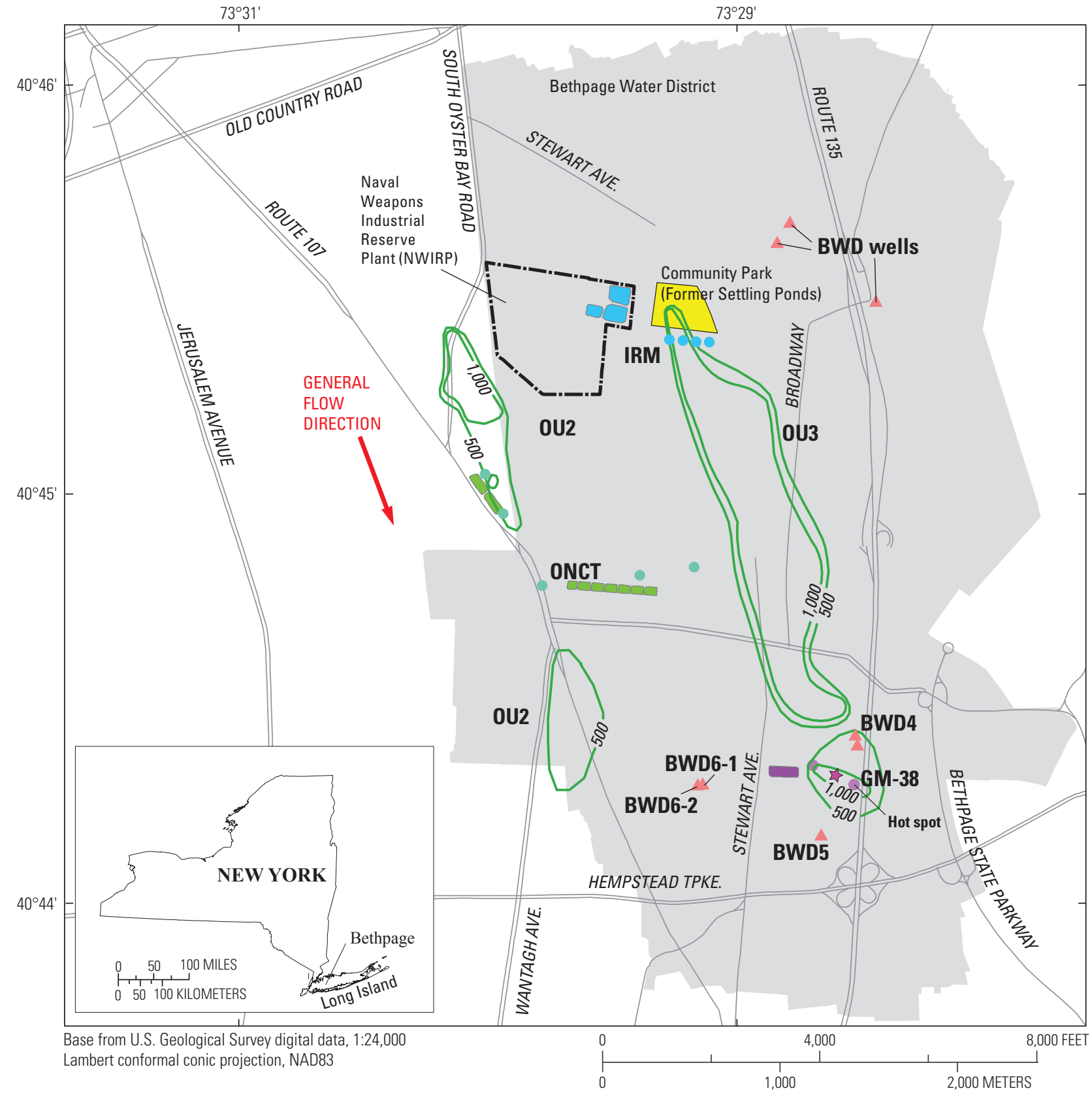

EXPLANATION

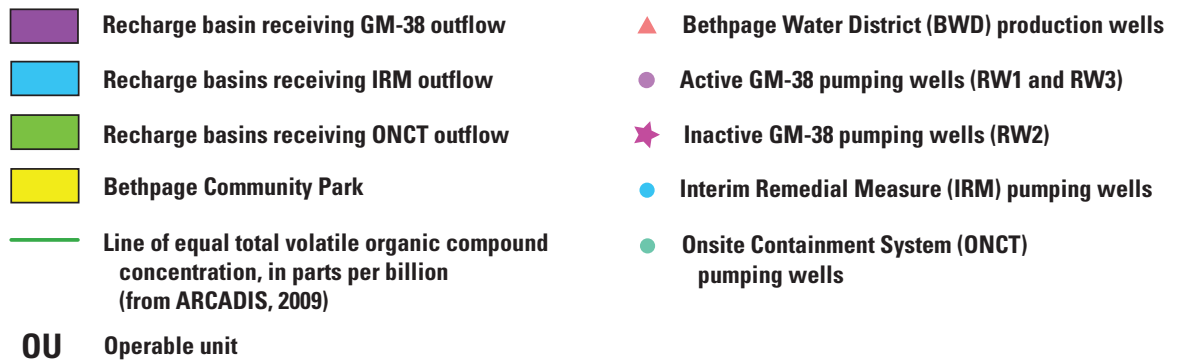

Figure 1. Generalized groundwater-flow direction, production wells, recharge basins, mapped volatile organic compound plumes adjacent to the Naval Weapons Industrial Reserve Plant (NWIRP), and other local features, Bethpage, New York. (Modified from ARCADIS, 2009) 
operation for about 1 year (NYSDEC, 2013). The OU3 plume appears to have emanated from the settling ponds and the IRM area to the east of the NWIRP (fig. 1). At present, about 3500 gallons per minute ( $\mathrm{gal} / \mathrm{min}$ ) is pumped from the OU2 ONCT hydraulic containment system, and $250 \mathrm{gal} / \mathrm{min}$ is pumped from the OU3 IRM hydraulic containment system. A remedial investigation work plan was also completed in 2013 to address an existing ice skating rink within the Bethpage community park and the OU3 IRM (fig. 1; NYSDEC, 2013).

The GM-38 Hot Spot is a distinct shallow plume with TVOC concentrations in groundwater of more than 500 ppb, about 8,000 feet (ft) to the southeast of the IRM of the OU3 plume and directly downgradient, based on the 2010 U.S. Geological Survey (USGS) regional water-table map of (Monti and others, 2013). The lower boundary of the GM-38 Hot Spot is about $350 \mathrm{ft}$ below sea level and the upper boundary is about $100 \mathrm{ft}$ below sea level (TVOC data and interpretation from ARCADIS (2009) and Tetra Tech (2002)). Presently, the GM-38 Hot Spot is being remediated by a treatment system that has been operated by the Navy since 2009. The GM-38 system consists of two extraction wells, RW1, which pumps $800 \mathrm{gal} / \mathrm{min}$, and RW3, which pumps $300 \mathrm{gal} / \mathrm{min}$. An additional well, RW2, is inactive and considerable infrastructure changes would be required to activate it. RW2 was not activated because during the initial testing this well was determined to be directly connected to the same portion of the aquifer as the Bethpage Water District (BWD) production wells at well field 4 (fig. 1). Due to concerns that operating RW2 could affect the operation of BWD4, it was agreed to install RW3 to replace RW2 (D. Brayack, TetraTech, written commun. 2013). Groundwater captured at GM-38 remedial wells is piped to an air stripping and liquid phase granular activated carbon adsorption plant, treated to NYSDEC State Pollutant Discharge Elimination System (SPDES) standards, then transferred to a nearby recharge basin where the effluent percolates downward and reenters the groundwater system. To operate the GM-38 system effectively, the pumping rates of RW1 and RW3 may be optimized. In addition to understanding the effect of the GM-38 system on Hot Spot containment, it is also desirable to understand how the GM-38 system affects hydraulic interference and zones of contribution (ZOCs) of nearby public supply wells. Furthermore, it is desirable to understand how the following affect GM-38 ZOCs: other pumping wells associated with the NWIRP, groundwater recharge from precipitation, and the regional flow system of Long Island. Public-supply production wells in the vicinity of the NWIRP include well BWD4 upgradient of the GM-38 site, well BWD5 downgradient of GM-38, and well BWD6-2 about equidistant between the southern OU2 $500 \mathrm{ppb}$ plume remnant contour to the west, and the GM-38 500 ppb Hot Spot contour to the east (fig. 1). Public-supply production wells typically pump about 2 million gallons per day (Mgal/d), with higher rates during the summer months. There have been extended periods of pump-shutoff during development of well field water treatment systems.

\section{Purpose and Scope}

This report presents the results of a study undertaken to provide a better understanding of ZOCs of the GM-38 wells. The study evaluated advective groundwater-flow patterns through groundwater-flow simulation and particle-tracking analysis in forward and backward modes. The groundwaterflow simulation and particle-tracking analysis had the following general objectives:

1. Delineate GM-38 ZOCs during present conditions through backward tracking of particles that are initiated at wells.

2. By use of hypothetical simulations, determine hydrogeologic and pumping-rate controls on the size and shape of GM-38 ZOCs.

The report contains a description of simulations and analyses that meet the study objectives. As a result of simulation analysis, further field-data collection activities that may improve ZOC delineation are discussed. A discussion of the limitations of this approach is also included.

\section{Previous Investigations}

Simulation of the groundwater-flow system of Nassau County began prior to the advent of computers through the use of electric-analog models (Getzen, 1977). Smolensky and Feldman (1995) simulated groundwater-flow paths in the Bethpage area in cooperation with the Nassau County Department of Health (NCDH) through the use of the USGS codes MODFLOW (McDonald and Harbaugh, 1988) and MODPATH (Pollock, 1994). At the time of the analysis (1992), groundwater flowed (1) towards deep industrial pumping wells, and (2) away from surface recharge basins where water captured by industrial wells was reintroduced. This pumping-recharge cycle resulted in rearrangement and partial containment of a plume of VOCs, which was migrating in a generally southward direction at a rate of about $200 \mathrm{ft} / \mathrm{yr}$ as described by Smolensky and Feldman (1995). The analysis also indicated that some groundwater upgradient of surface recharge basins was drawn into the deep zones of industrial well influence, but not captured, and ultimately discharged to the far southern model boundary in the bottom part of the Magothy aquifer, near the contact with the underlying Raritan confining unit as described by Smolensky and Feldman (1995). From 1995 to the present, consultants developed a series of MODFLOW, MODPATH, and MT3D (Zheng, 1990) models that are generally consistent with the earlier USGS work but depict greater containment of VOCs upgradient of the ONCT and continued southward migration of VOCs downgradient from the ONCT (ARCADIS, 2009). A timeline of the modeling efforts is given in Misut (2011).

Development of the GM-38 water treatment system is described in Tetra Tech (2002), and the results of water quality and hydrogeologic investigations in the vicinity of the GM-38 site are presented in ARCADIS (2009). 


\section{Methods}

Simulation of groundwater flow and advective transport included flow modeling using MODFLOW-2005 (Harbaugh, 2005), generation of alternate equiprobable hydraulic property distributions using transitional probability methods (Carle, 1999), and particle tracking analysis using MODPATH version 6 (Pollock, 2012).

\section{Simulation of Groundwater Flow and Sources of Water to Wells}

The numerical calculations of the various ZOC cases investigated in this study are carried out using the USGS MODFLOW-2005 suite of codes (Harbaugh, 2005) coupled with MODPATH version 6 (Pollock, 2012). The model is documented according to USGS guidelines (USGS, 1996, http://water.usgs.gov/admin/memo/GW/gw96.04.html). Due to use of transitional probability methods (Carle, 1999) to represent Magothy aquifer heterogeneity, the MODFLOW model was finely discretized into 70 layers in the subgrid of heterogeneity representation.

\section{Model Development}

To fully describe the groundwater-flow model, the following topics are treated: (1) hydrologic system under investigation, (2) mathematical methods used, (3) model spatial and temporal discretization, (4) aquifer system properties, (5) stresses modeled, (6) transient modeling, (7) calibration criteria, procedure, and results, and (8) limitations of the model of the actual system and the impact those limitations have on the results and conclusions of the report.

\section{Hydrologic System Under Investigation}

The Bethpage area and GM-38 remedial wells are situated within the Long Island groundwater system, which has been described in previous USGS publications (Smolensky and Feldman, 1995; Busciolano, 2005; and Misut and Busciolano, 2009). The aquifer and confining units in the Bethpage area are described in table 1. The average horizontal hydraulic conductivity of the upper glacial, Magothy, and Lloyd aquifers is 270, 50, and 60 feet per day $(\mathrm{ft} / \mathrm{d})$, respectively. The estimated ratio of horizontal to vertical hydraulic conductivity is 10:1 for the upper glacial and Lloyd aquifers and 100:1 for the Magothy aquifer. Recharge to the groundwater system is from precipitation that infiltrates downward through an unsaturated zone. Recharge is locally enhanced by constructed recharge basins. Groundwater also enters the area by lateral flow from the regional Long Island system. Discharge from the groundwater system is to pumping wells and gaining streams that occupy former glacial meltwater channels. Across the study area, the uppermost aquifer is an unconfined upper glacial aquifer, except to the north, where the water table is in the deeper semi-confined Magothy aquifer (fig. 2). Even though the uppermost aquifer

Table 1. Characteristics of hydrogeologic units, Bethpage, New York.

[From Misut and Aphale (2014); ft, feet]

\begin{tabular}{|c|c|c|}
\hline Hydrogeologic unit & Geologic unit & Description and hydraulic properties \\
\hline Upper glacial aquifer & Upper Pleistocene deposits & $\begin{array}{l}\text { Till and outwash deposits of sand, silt, clay, and boulders. Varied } \\
\text { permeability with an average hydraulic conductivity of } 270 \text { feet per } \\
\text { day and a horizontal to vertical anisotropy of } 10: 1 \text {. Outwash has the } \\
\text { highest hydraulic conductivity. About } 100 \mathrm{ft} \text { thick. }\end{array}$ \\
\hline Magothy aquifer & $\begin{array}{l}\text { Matawan Group-Magothy Formation, } \\
\text { undifferentiated }\end{array}$ & $\begin{array}{l}\text { Fine sand with silt and interbedded clay, with basal gravel. Gray and } \\
\text { pale yellow quartz sand. Lignite is common. Moderately permeable } \\
\text { with an average hydraulic conductivity of } 50 \text { feet per day and an } \\
\text { anisotropy of } 100: 1 \text {. About } 800 \mathrm{ft} \text { thick. }\end{array}$ \\
\hline $\begin{array}{l}\text { Raritan confining unit } \\
\text { (Raritan clay) }\end{array}$ & $\begin{array}{l}\text { Unnamed clay member of the Raritan } \\
\text { Formation }\end{array}$ & $\begin{array}{l}\text { Clay; solid with multicolors such as gray, white, red, or tan. Very } \\
\text { poorly permeable. Confines water underlying unit. Average hydrau- } \\
\text { lic conductivity of } 0.001 \text { foot per day. About } 200 \mathrm{ft} \text { thick. }\end{array}$ \\
\hline Lloyd aquifer & $\begin{array}{l}\text { Lloyd Sand Member of the Raritan } \\
\text { Formation }\end{array}$ & $\begin{array}{l}\text { Underlies the Raritan confining unit. Fine to coarse sand and gravel } \\
\text { with clay lenses. White and pale-yellow sand well sorted. Moder- } \\
\text { ately permeable with an average horizontal hydraulic conductivity } \\
\text { of } 60 \text { feet per day, and anisotropy of } 10: 1 \text {. About } 200 \mathrm{ft} \text { thick. }\end{array}$ \\
\hline Bedrock & Hartland Formation; crystalline bedrock & $\begin{array}{l}\text { Biotite-garnet schist overlain by a thick saprolitic zone } 50 \text { to } 100 \mathrm{ft} \\
\text { thick, consisting of white, yellow, and gray clay. Impermeable to } \\
\text { poorly permeable. }\end{array}$ \\
\hline
\end{tabular}




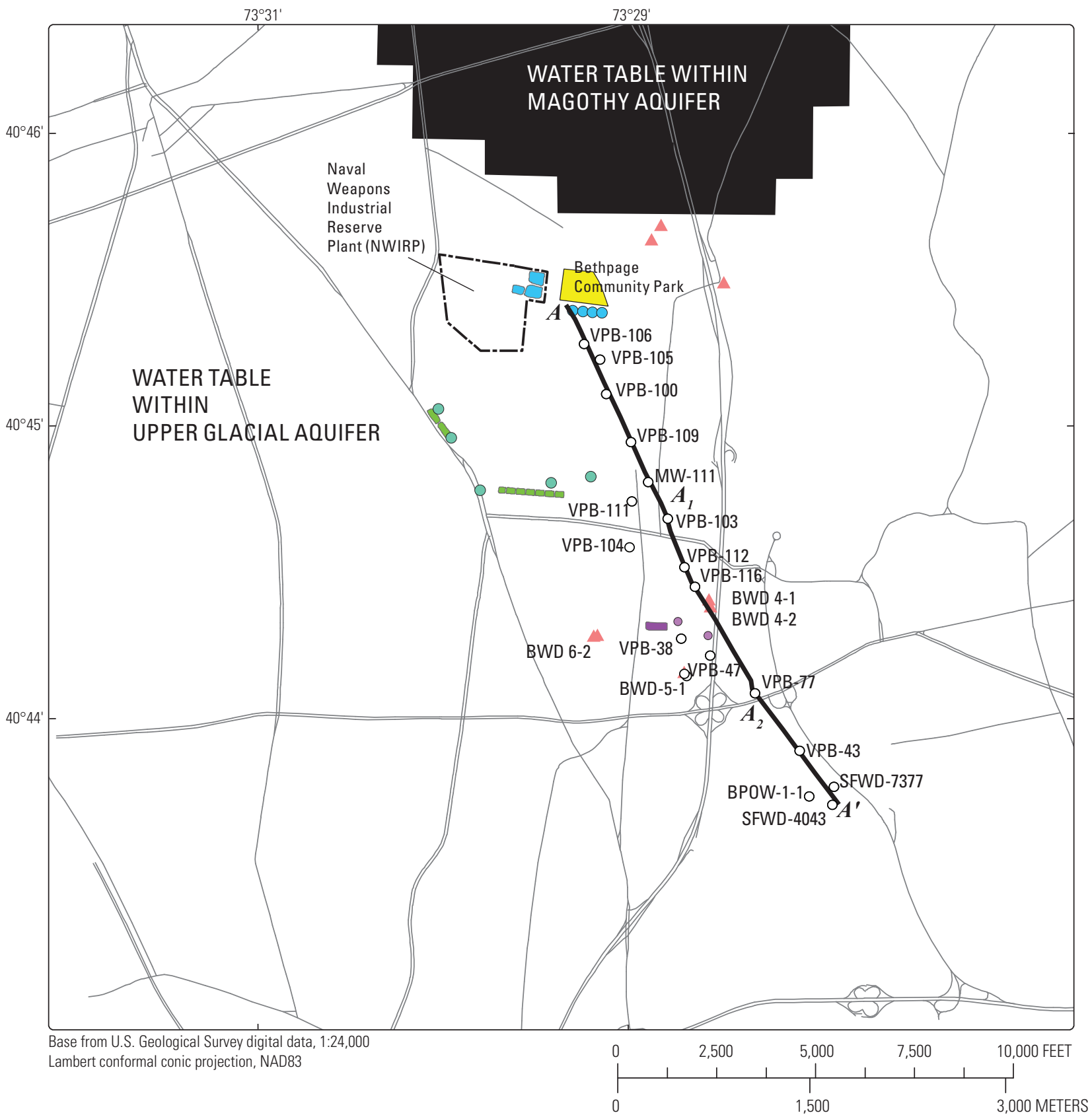

EXPLANATION

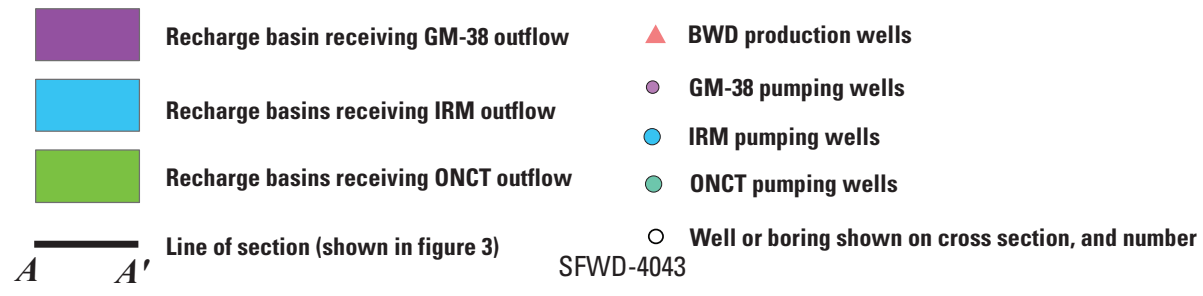

Figure 2. Aquifer within which water table is present and location of boreholes of hydrogeologic section $A-A^{\prime}$, Bethpage, New York. (Water table location calculated from water table data of Monti and others, 2013; Magothy aquifer top elevation from Smolensky and others, 1989) 
near GM-38 is the glacial aquifer, the Magothy aquifer is the primary aquifer of concern for VOCs. Within the Magothy aquifer, sands and gravels are interbedded with fine-grained sediments. Fine-grained sediments, as reported on driller's logs, are delineated on section A-A' (fig. 3) through the GM-38 site. Appendix 1 cross references local well numbers used in this report to New York State and national USGS well identification numbers.

Lower local groundwater subsystem boundaries may be considered the top of the Raritan confining unit, at about 600 to $800 \mathrm{ft}$ below sea level, or the relatively impermeable bedrock, at about 1,000 to 1,200 ft below sea level (table 1). The Raritan confining unit is estimated to be 150 to $200 \mathrm{ft}$ thick near GM-38 (Smolenksy and others, 1989, fig. 4); the top of the Raritan confining unit has been found in recent boreholes VPB-137, 138 and 139 (fig. 4, data from Resolution Consultants, 2014) to be about 200 feet deeper than indicated by (Smolenksy and others, 1989). The regional hydraulic gradient from the Lloyd aquifer across the Raritan confining unit into the Magothy aquifer is very low (Monti and others, 2013), from about 0.15 [ft per $\mathrm{ft}]$ at the northeast of the study area to 0.03 [ft per $\mathrm{ft}$ ] in the southwest; furthermore, given a Raritan confining unit vertical conductivity of about $0.001 \mathrm{ft} / \mathrm{d}$, upward flow from the Raritan confining unit into the Magothy aquifer is likely negligible.

\section{Mathematical Methods Used}

The numerical calculations of the various ZOC cases investigated in this study are carried out using flow fields represented by a finite difference grid and simulated by the MODFLOW-2005 suite of codes (Harbaugh, 2005) through solution of the groundwater flow equation using finite difference techniques. Particles are tracked through the simulated flow fields using MODPATH version 6 (Pollock, 2012). The graphical user interface ModelMuse (http:// water.usgs.gov/nrp/gwsoftware/ModelMuse/ModelMuse. html; Winston, 2009) is used to aid the input of data and the post processing of model results. The MODFLOW

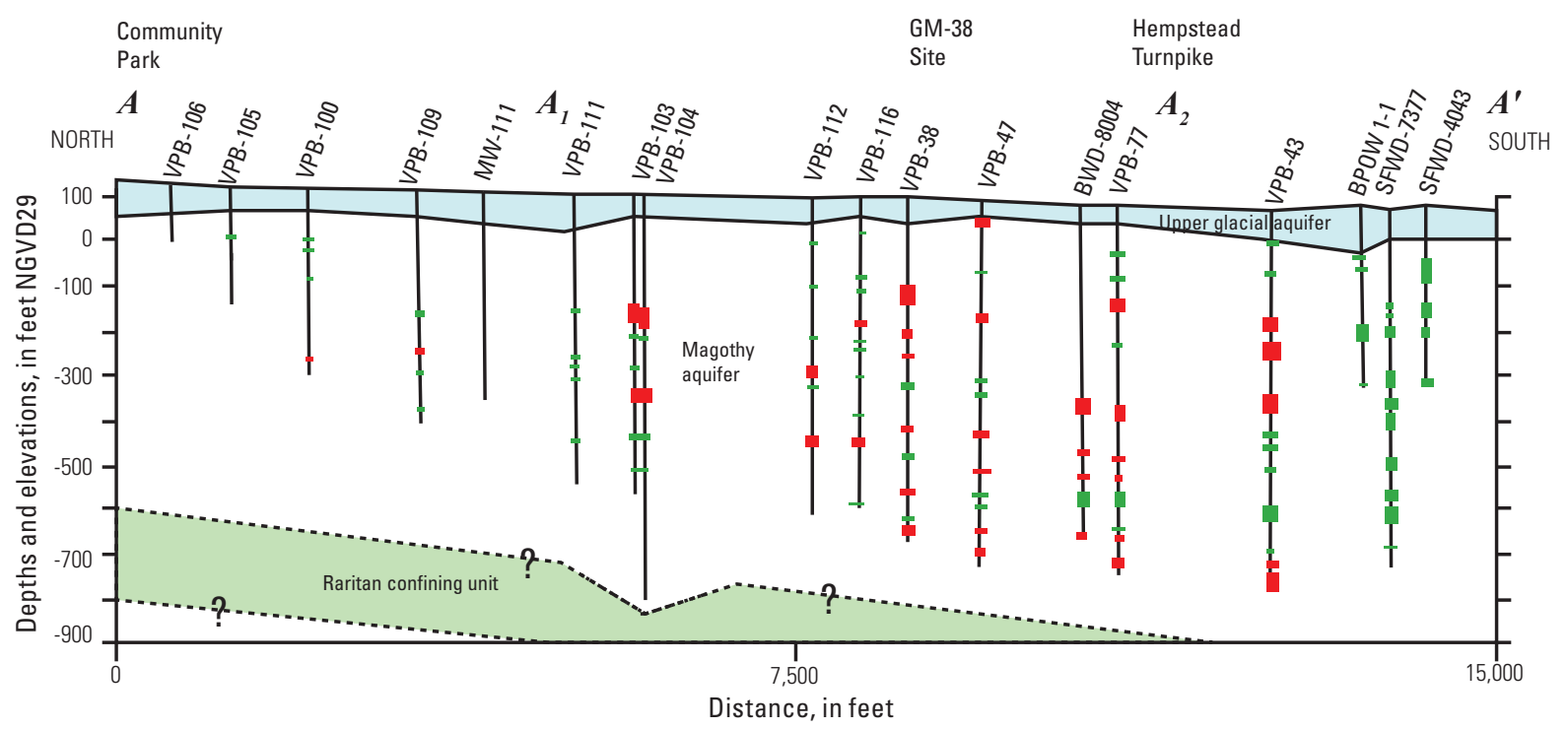

EXPLANATION

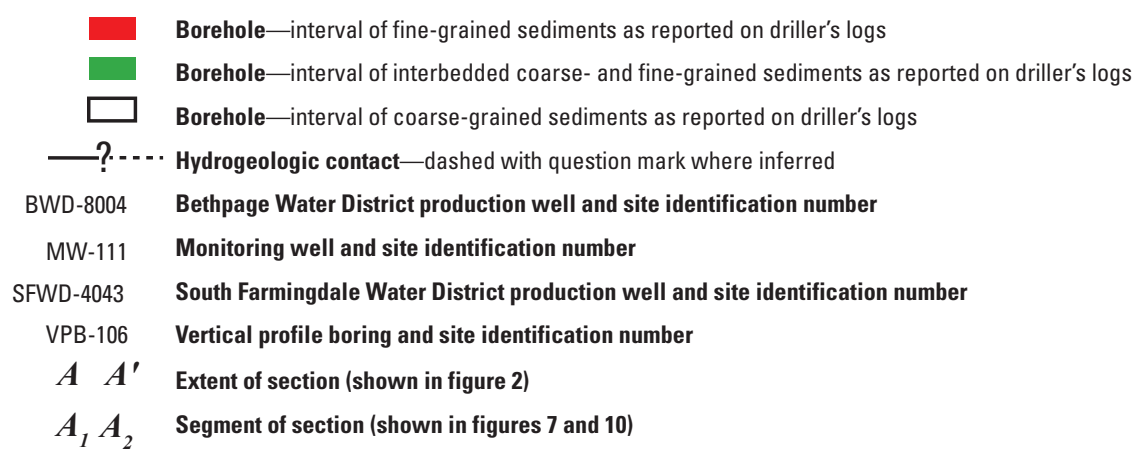

Figure 3. Section $A-A^{\prime}$ through $\mathrm{GM}-38$ area showing hydrogeologic units and borehole intervals of fine-grained sediments, Bethpage, New York. (From Tetra Tech, 2012a, Smolensky and others, 1989 and D. Brayack, written communication, 2013) 


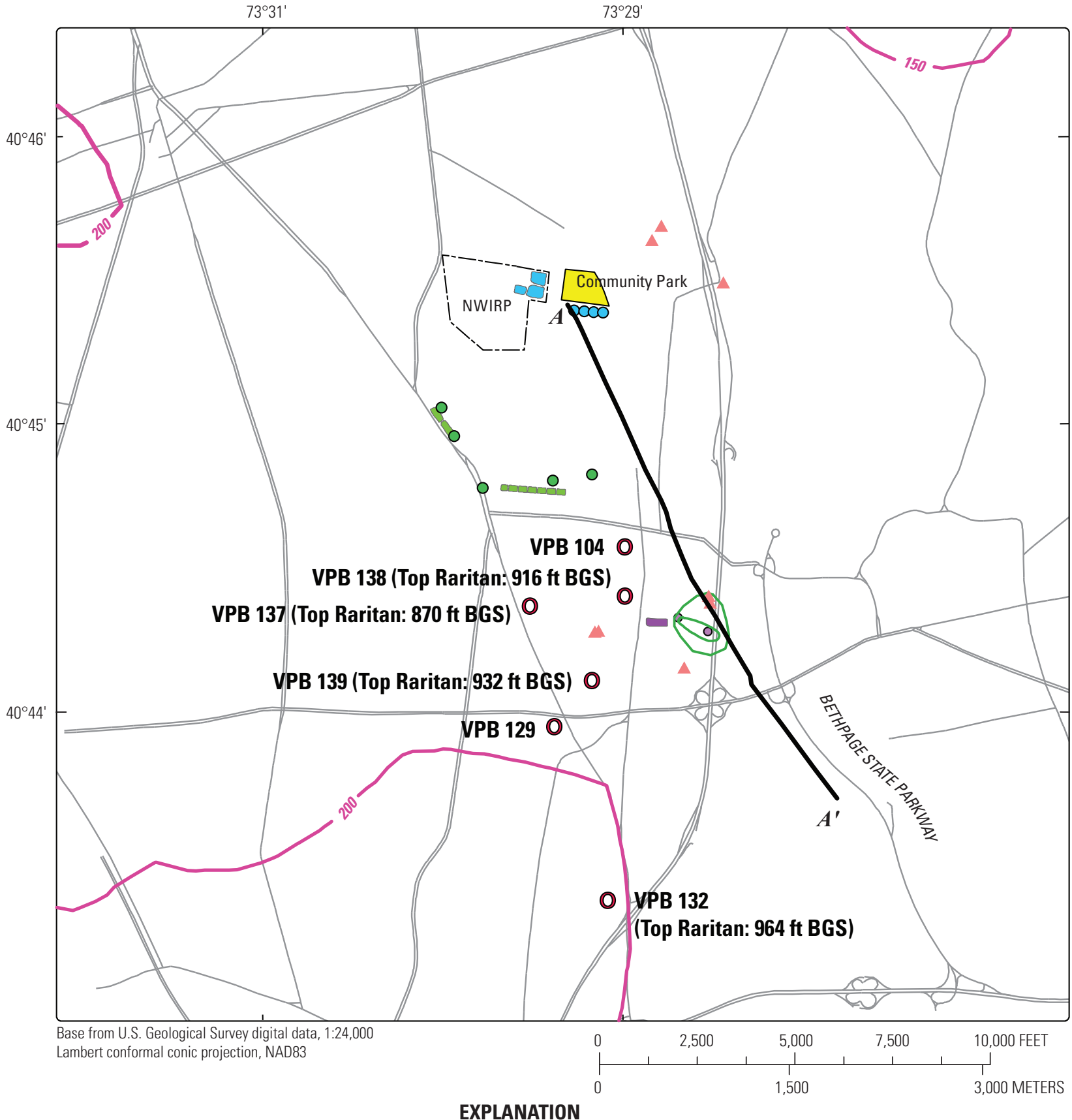

EXPLANATION

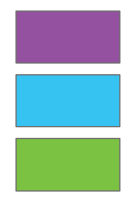

Recharge basin receiving GM-38 outflow

Recharge basins receiving IRM outflow

Recharge basins receiving ONCT outflow

Line of equal total volatile organic compound concentration, in parts per billion (from ARCADIS, 2009)

Line of equal thickness of Raritan confining unit, , in feet. (from Smolensky and others, 1989)

Line of section (shown in figure 3 )

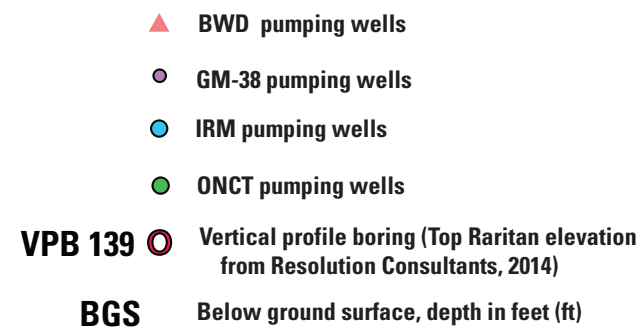

BGS

Figure 4. Thickness of Raritan confining unit, boreholes drilled to depths greater than 700 feet below the North American Vertical Datum of 1988, location of section $A-A^{\prime}$, and other local features, Bethpage, New York. (Data from Smolensky and others, 1989 and Resolution Consultants, 2014) 
suite (http://water.usgs.gov/nrp/gwsoftware/modflow.html) represents three-dimensional geometry and complex boundary conditions, allows for variably spaced model discretization, and can be utilized by particle tracking methods to delineate ZOCs to wells.

Particle tracking evaluations were made for representative present steady state conditions using MODPATH version 6 (Pollock, 2012), which accounts for advective transport but does not consider dispersive transport or chemical reactions. Advective particle tracking was used to develop the ZOCs for the study area. Dispersion from molecular diffusion is relatively small in a high-velocity system, so it is assumed to be negligible. Hydrodynamic dispersion due to geologic heterogeneity was accounted for by considering multiple realizations of the distribution of hydrogeologic properties.

The transition probability geostatistical software T-PROGS (Carle, 1999) was used to generate alternative realizations of high-permeability sands and low-permeability clay bedding within the Magothy aquifer. Transition probability and Markov chain methods use geologic data to compute the probability that a particular geologic unit is encountered given the location of nearby geologic units. Once the probabilities are computed, equiprobable realizations of hydrogeologic properties can be created based on the known lithologies measured in the boreholes. This method ensures the model matches reality at all measured locations and matches the statistics of the system at all unmeasured locations. Vertical transition probabilities for this study were estimated from the borehole logs, and horizontal transition probabilities were estimated using default settings in T-PROGS that describe the typical ratio of vertical to horizontal heterogeneity.

\section{Boundary Conditions}

The north and south boundaries of the groundwater-flow model (grid is rotated 10 degrees counterclockwise, fig. 5) are represented as constant head boundaries. The east and west model boundaries are represented as no-flow boundaries where flow is parallel to the side. Head values for the boundary conditions are estimated from USGS 2006 regional contour maps, which are representative of present steady state conditions (Monti and Busciolano, 2009). Justification for the use of constant-head boundaries in Long Island groundwaterflow models is given in Misut and Feldman (1996). Recharge is a specified flux boundary with several factors affecting the rate, as described by the model stresses section below. MODFLOW drain boundaries are used to represent three streams draining to the south of the model (Massapequa, Seaford, and Bellmore Creeks). The heads for these drains are also taken from Monti and Busciolano (2009). Flow at Massapequa and Belmore Creeks is reported at http://nwis. waterdata.usgs.gov/ny/nwis/sw. Pumpages are specified flux boundaries and are described in the "Model stresses" section.

\section{Model Spatial and Temporal Discretization}

The areal extent of the model grid (fig. 6) is similar to that described by ARCADIS (2010), with finer grid spacing in the vicinity of GM-38 (fig. 6). The number of rows (213) and columns (144), along with the number of model layers (80) results in about 2 million cells total. For a GM-38 subarea (inner region of model grid, fig. 6), the Magothy aquifer heterogeneity is represented using the transitional probability approach, and particle tracking of GM-38 ZOCs are conducted. Fine horizontal and vertical discretization is necessary in the inner region to represent the discontinuous character of the fine-grained sediments and to simulate the influence of these structures on particle pathways. The grid layering is coarse in the upper glacial aquifer, fine in the Magothy aquifer, and coarse in the Raritan formation. The bottom of the top layer is at sea level, a conservative level below the water table that prevents model cells from dewatering, which would introduce nonlinearity into the MODFLOW numerical solution. The top of the GM-38 Hot Spot is located within the finely discretized inner region of the Magothy aquifer. The bottom no-flow boundary of the model is chosen to be the base of unconsolidated deposits in the area (base of the Lloyd aquifer), in order to fully represent the groundwater flow system as has been done by other Nassau County groundwater flow models such as (Misut and Aphale, 2014).

A steady state model was used to simulate average present hydrologic conditions. Transient conditions were simulated with a model using the steady-state hydraulic parameters in order to demonstrate the validity and sensitivity of the steady-state assumptions. Steady state assumptions may introduce some error into the study results as a consequence of averaging changing conditions and employing single input parameters. For example, public-supply pumpage varies in ways that cannot be fully represented by a steady state model. The steady state assumption also was used in the ARCADIS model (ARCADIS, 2010) and described in Misut (2011). Use of a steady state model to address similar project objectives has been justified in other USGS model reports, such as Smolenksy and Feldman (1995) and Reilly and Pollock (1995). During 2013, an aquifer test was done by the Navy, and detailed time series of well pumping rates and corresponding water-level responses were recorded at numerous locations, which are given in Tetra Tech (2013). These data were used to verify the current USGS model and demonstrate the sensitivity of model results to certain transient-state changes, described below.

\section{Aquifer System Properties}

Aquifer system properties are summarized in table 1. For the inner fine grid, geometry of Magothy aquifer and confining 


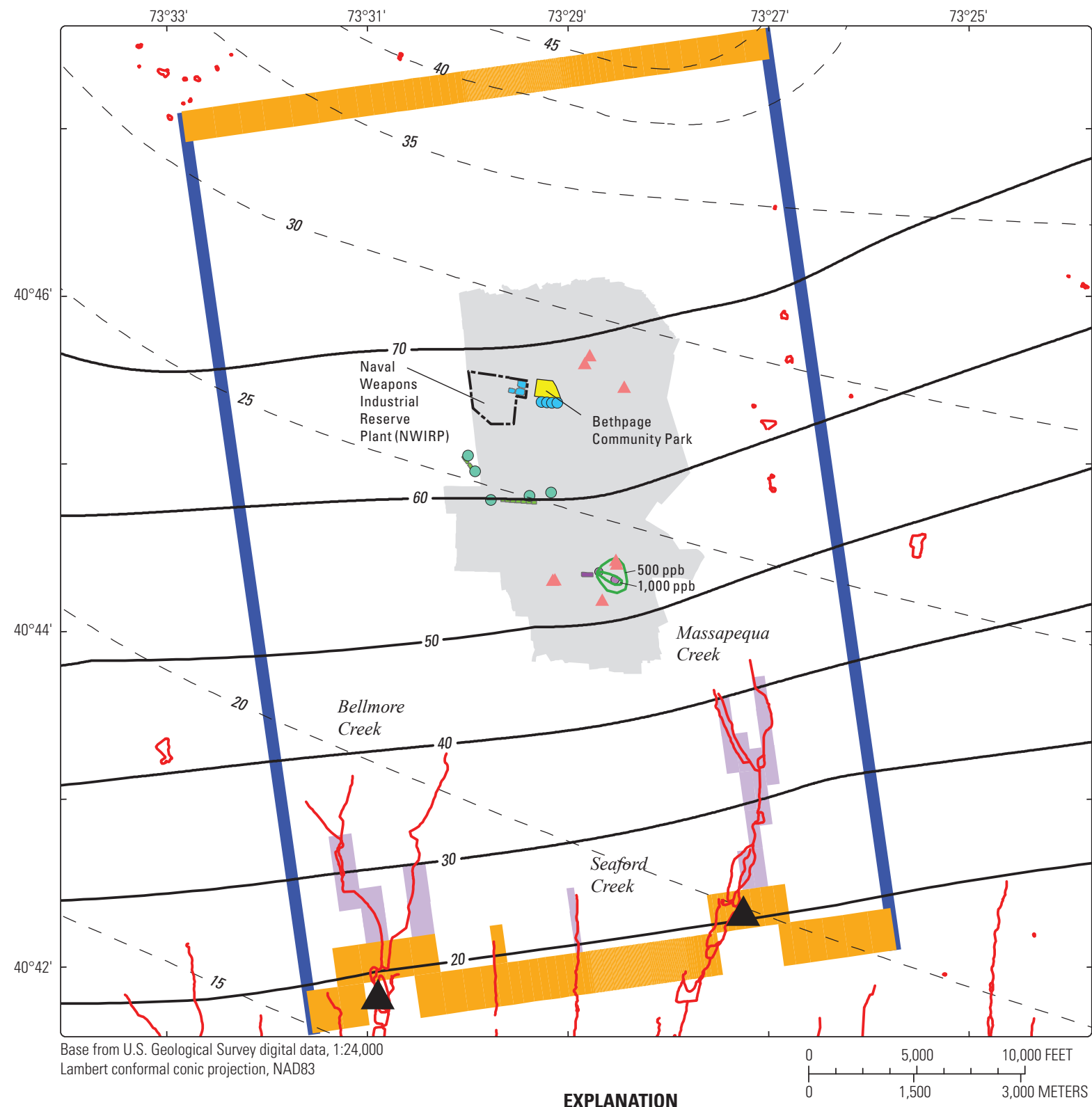

EXPLANATION
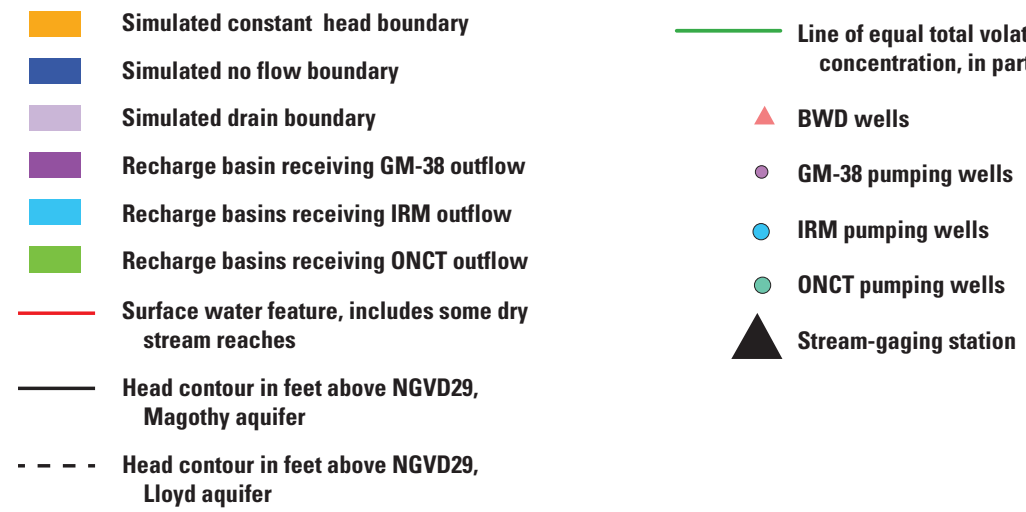

Figure 5. Specified production wells, model drain cells, creeks, stream-gaging stations, model constant head cells, water-level contours, no-flow model boundaries, and other local features, Bethpage, New York. 


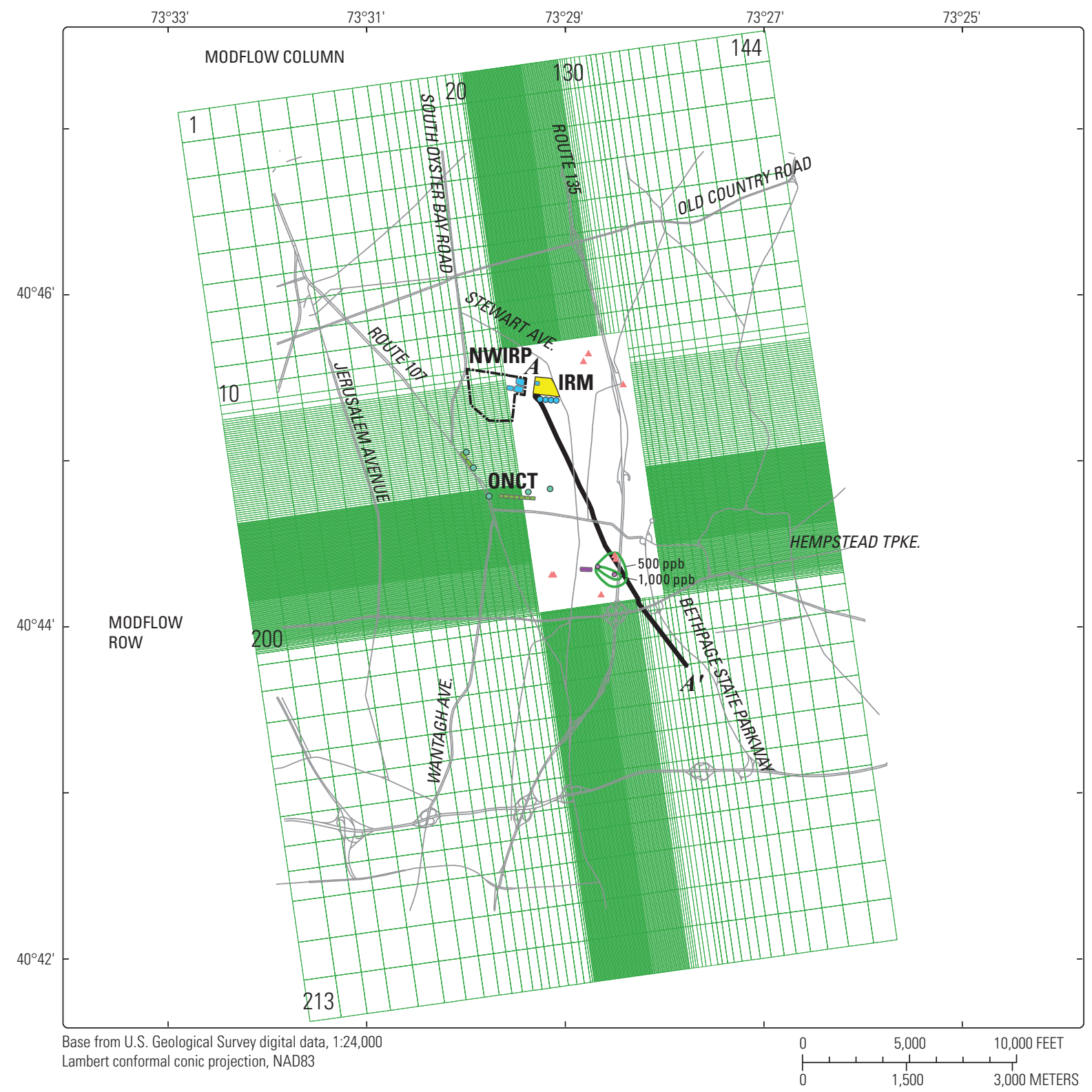

\section{EXPLANATION}

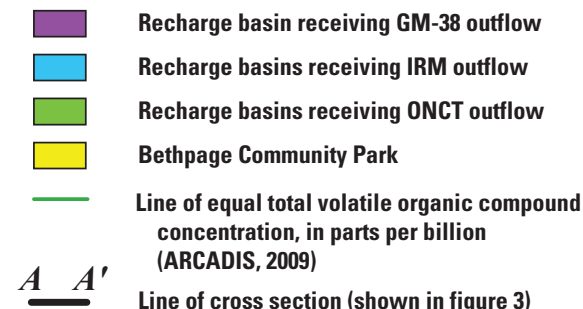

Bethpage Water District pumping wells

- GM-38 pumping wells

Interim Remedial Measure pumping wells

Onsite Containment System pumping wells

$\boldsymbol{A}^{\prime}$ Line of cross section (shown in figure 3)

Figure 6. Outer region of MODFLOW model grid showing row and column numbers, the GM-38 Hot Spot (from ARCADIS, 2009), the location of section $A-A^{\prime}$, and other local features, Bethpage, New York. 
beds was generated using transition probability methods. The aquifer properties are discussed in more detail in Smolenksy and Feldman (1995) and ARCADIS (2003). Spatial variations of aquifer properties were derived from McClymonds and Franke (1972) and Smolensky and others (1989). Initial hydraulic conductivity values were estimated for the hydrogeologic units using specific-capacity data from drillers' logs and other methods and summarized in McClymonds and Franke (1972). Initial effective porosity values for all model layers are 0.25 as used by ARCADIS (2010). Storage parameters applied in previous modeling studies on Long Island are summarized by Buxton and Smolenksy (1999), with specific yield values ranging from 0.1 (Magothy aquifer) to 0.3 (glacial outwash) and a specific storage of $6.0 \times 10^{-7}[1 / \mathrm{ft}]$ for all confining units. Misut and Busciolano (2009) estimated the specific storage of the upper Magothy to be $5.0 \times 10^{-6}[1 / \mathrm{ft}]$. Simulated aquifer system properties were refined during model calibration as data became available through an ongoing Navy drilling program (D. Brayack, written communication, 2013), including addition of a basal zone of the Magothy aquifer and lowering the altitude of top of the Raritan confining unit. The horizontal and vertical hydraulic conductivity of the Raritan confining unit is $0.001 \mathrm{ft} / \mathrm{d}$ (isotropic).

Initial parameter values for the main part of the Magothy aquifer included a horizontal hydraulic conductivity of 50 feet per day $(\mathrm{ft} / \mathrm{d})$ and a vertical hydraulic conductivity of $0.5 \mathrm{ft} / \mathrm{d}$. These values relate to implicit representation of local confining layers within the Magothy aquifer through an anisotropy factor (ratio of horizontal to vertical hydraulic conductivity) of 100:1. However, local confining layers within the Magothy aquifer are further represented as a sequence of three (A, B, C) conditional stochastic simulations - multiple, equally probable spatial distributions that honor borehole data within $1,000 \mathrm{ft}$ of the GM-38 Hot Spot, including vertical profile borings of section A-A' (figs. 2, 3) and geologic logs of BWD plant 6-2 (fig. 2). These distributions were not screened from a larger population of distributions and therefore do not represent a Monte Carlo analysis; they are simply the only distributions generated; each provides a reasonable match to the observed data and interpretations of confining bed structures given in Tetra Tech (2012a).

Sedimentary facies in the Magothy aquifer identified in the borings and the monitoring and public-supply wells at the GM-38 site include: (a) coarse-grained sediments of predominantly fine to medium sand, (b) finer-grained sediments of predominantly clay and sandy clay, and (c) interbedded coarse and fine-grained sediments of predominantly clay and sands (figs. 3, 7, modified from TetraTech, 2012a). Coarse-grained sediments comprise about 83 percent of the Magothy aquifer material. Finer-grained and interbedded sediments comprise 9 and 8 percent, respectively. The identified facies intervals were input as hard data in the conditional simulation. A 10 - $\mathrm{ft}$ vertical sampling interval is used to represent these hard data. The conditional simulation subgrid (fig. 8) uses a regularly spaced grid of data points in 45 columns by 60 rows by 65 layers ( $100 \mathrm{ft}$ by $100 \mathrm{ft}$ by $10 \mathrm{ft}$ ); these data points overlap the inner zone of fine MODFLOW model discretization (fig. 6).

A matrix of facies vertical transiograms may be used to represent the probability of transitioning from one facies to another within a Markov chain. Discrete probabilities were computed every $2 \mathrm{ft}$ vertically using 5 - $\mathrm{ft}$ moving intervals over a lag range of zero to $30 \mathrm{ft}$ and are shown as points (fig. 9). To extend transition probabilities from hard data throughout the conditional simulation domain, it is necessary to construct continuous transition probability models (shown as lines in figure 9). While the transiogram matrix defines vertical transition probabilities, it is also necessary to define horizontal transition probabilities. To do this, a 1:60 ratio of vertical to horizontal transition probability was applied using the embedded transition probability method (Carle, 1999). Resultant conditional realization A is displayed (fig. 10) along part of section $\mathrm{A}-\mathrm{A}^{\prime}$ (location of section shown in fig. 2), as a 5-point buffer radius around the hard data, and as a block diagram within the regional flow model (fig. 11). Horizontal transitioning is isotropic and honors the hard data from the borings and wells.

Realizations differ slightly due to the probabilistic nature of the realization method, which requires seeding with a random number. Three equiprobable realizations (A, B, and $C$ ) were performed as a preliminary analysis of the role of heterogeneity on plume capture. Hundreds of similar equiprobable realizations can be made. While the three realizations probably do not represent a statistically significant sampling, the results demonstrate the influence on plume transport of uncertainty in distribution of fine-grained facies. All provided clear matches to the observed data and facies interpretations given in Tetra Tech (2012a). Realizations A and $\mathrm{B}$ were practically indistinguishable, while realization $\mathrm{C}$ was slightly different than realizations $\mathrm{A}$ and $\mathrm{B}$. Comparison of realizations $\mathrm{A}, \mathrm{B}$, and $\mathrm{C}$ near the GM-38 pumping wells (right corner to the southeast in fig. 12) shows that fewer model cells represent the fine-grained facies and the horizontal to vertical anisotropy is less in realizations A and B than in realization C. At the southwest corner of the heterogeneity realization blocks (foreground of fig. 12), the dominant fine-grained bed in the upper part of the block is noticeably thinner in realization $\mathrm{C}$ than in realizations A and $\mathrm{B}$, but a secondary fine-grained bed in the lower part of the block is also extended in realization C.

\section{Model Stresses}

Stresses applied as boundary conditions within the MODFLOW model include: pumping wells, using the MNW2 multinode well package (Konikow and others, 2009); recharge to the water table, using the $\mathrm{RCH}$ package embedded within MODFLOW-2005 (Harbaugh, 2005); streams, using the DRN package embedded within MODFLOW-2005; and constant head boundaries, using the CHD package embedded within MODFLOW-2005. Pumpage data (fig. 13) were compiled by the NYSDEC and include public supply, remedial, and golf-course pumpage. These data were averaged over the 


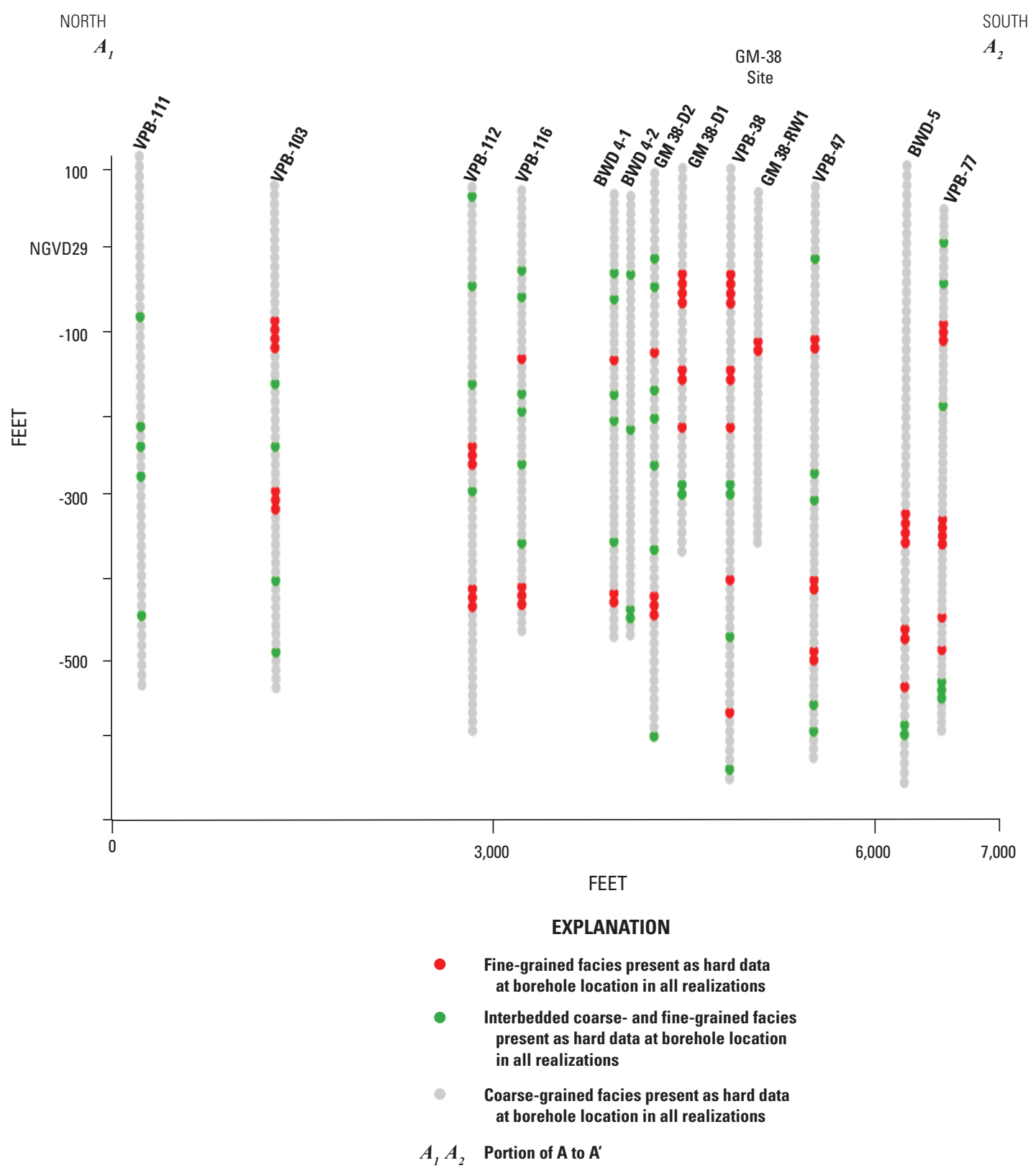

Figure 7. Distribution of coarse-grained, fine-grained, and interbedded facies identified in borings and wells along part of section $A-A^{\prime}$ (designated as $\mathrm{A} 1-\mathrm{A} 2$ ) that are used as hard data in conditional simulation of Magothy aquifer heterogeneity, Bethpage, New York. (Location of section $A-A^{\prime}$ shown in figure 2, modified from TetraTech, 2012a) 


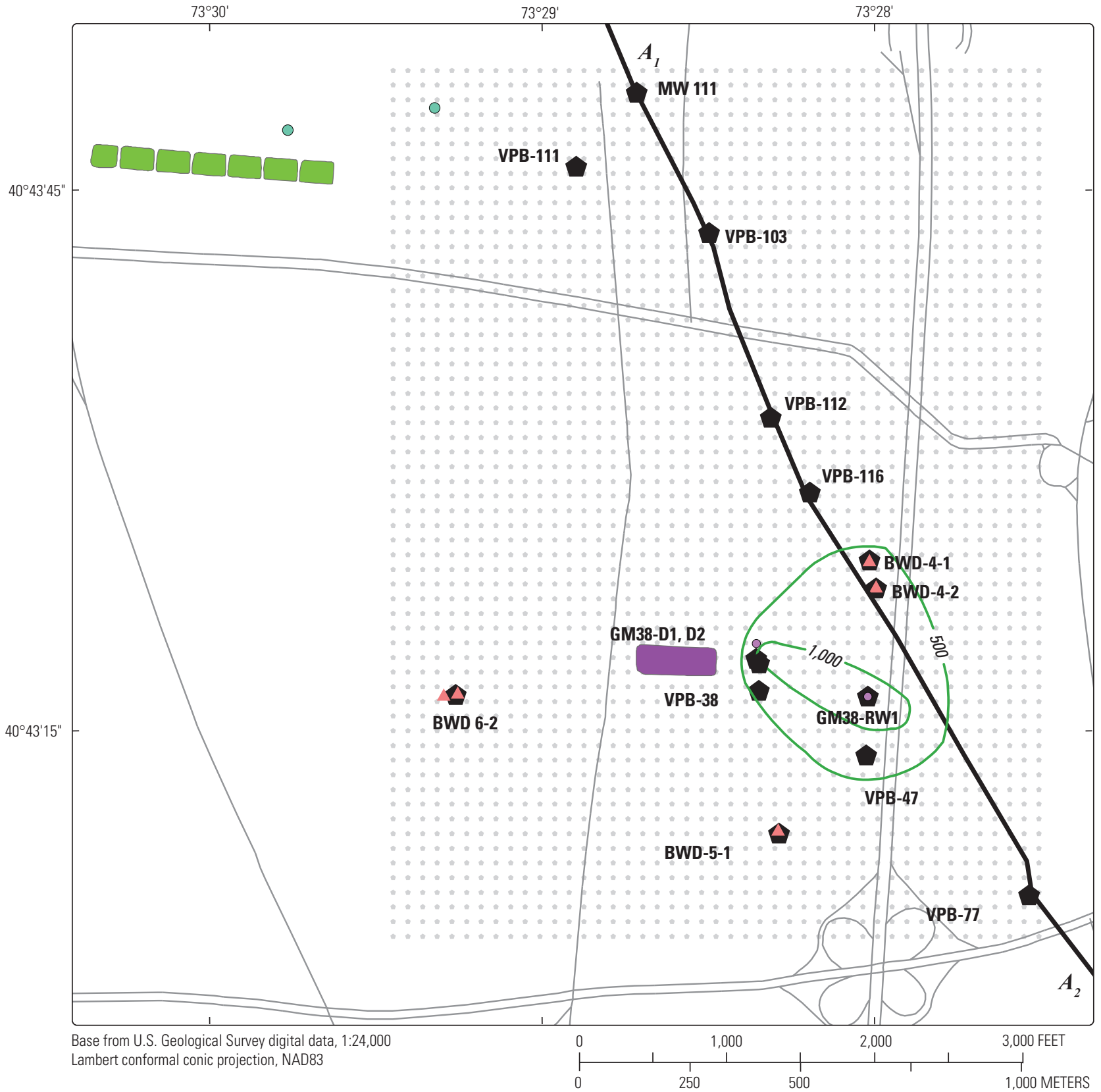

EXPLANATION

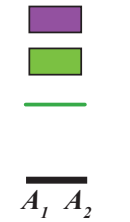

Recharge basin receiving GM-38 outflow

Recharge basins receiving ONCT outflow Line of equal total volatile organic compound concentration, in parts per billion (ARCADIS, 2009)

Portion of A to $A^{\prime}$
BWD pumping wells
GM-38 pumping wells
ONCT pumping wells
Borehole logs used as hard data in conditional simulation
Conditional simulation points

Figure 8. Conditional simulation subgrid showing GM-38 Hot Spot (from ARCADIS, 2009), boring and wells along part of section $A-A^{\prime}$, and other local features, Bethpage, New York. 

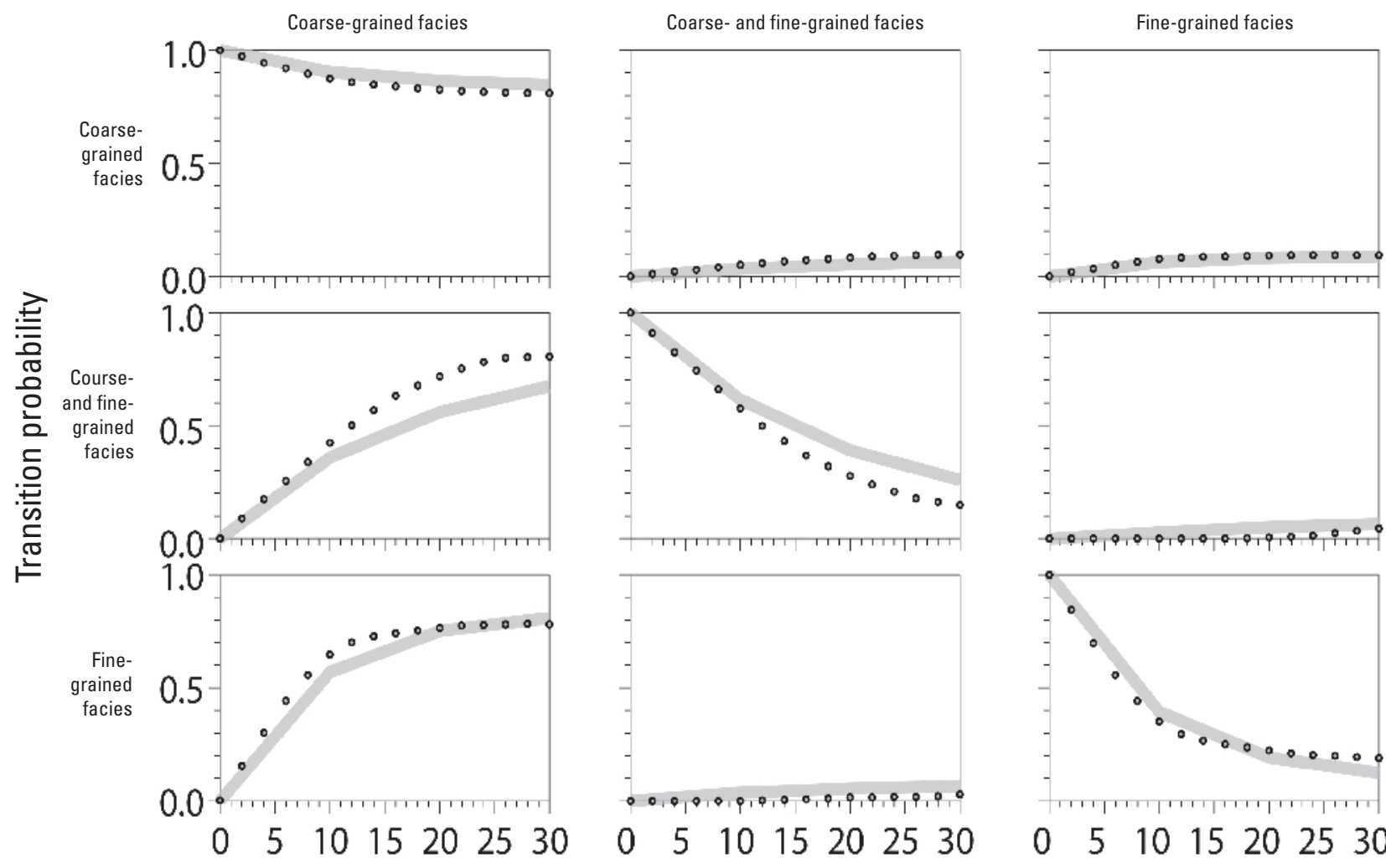

Lag (in feet)

\title{
EXPLANATION
}

\author{
○ $-\circ$ Discrete value of probability at lag distance \\ Continuous model of transition probablity at lag distance
}

Figure 9. Probability of transitioning between facies of the Magothy aquifer at vertical lag distances from 2 to 30 feet, Bethpage, New York. 


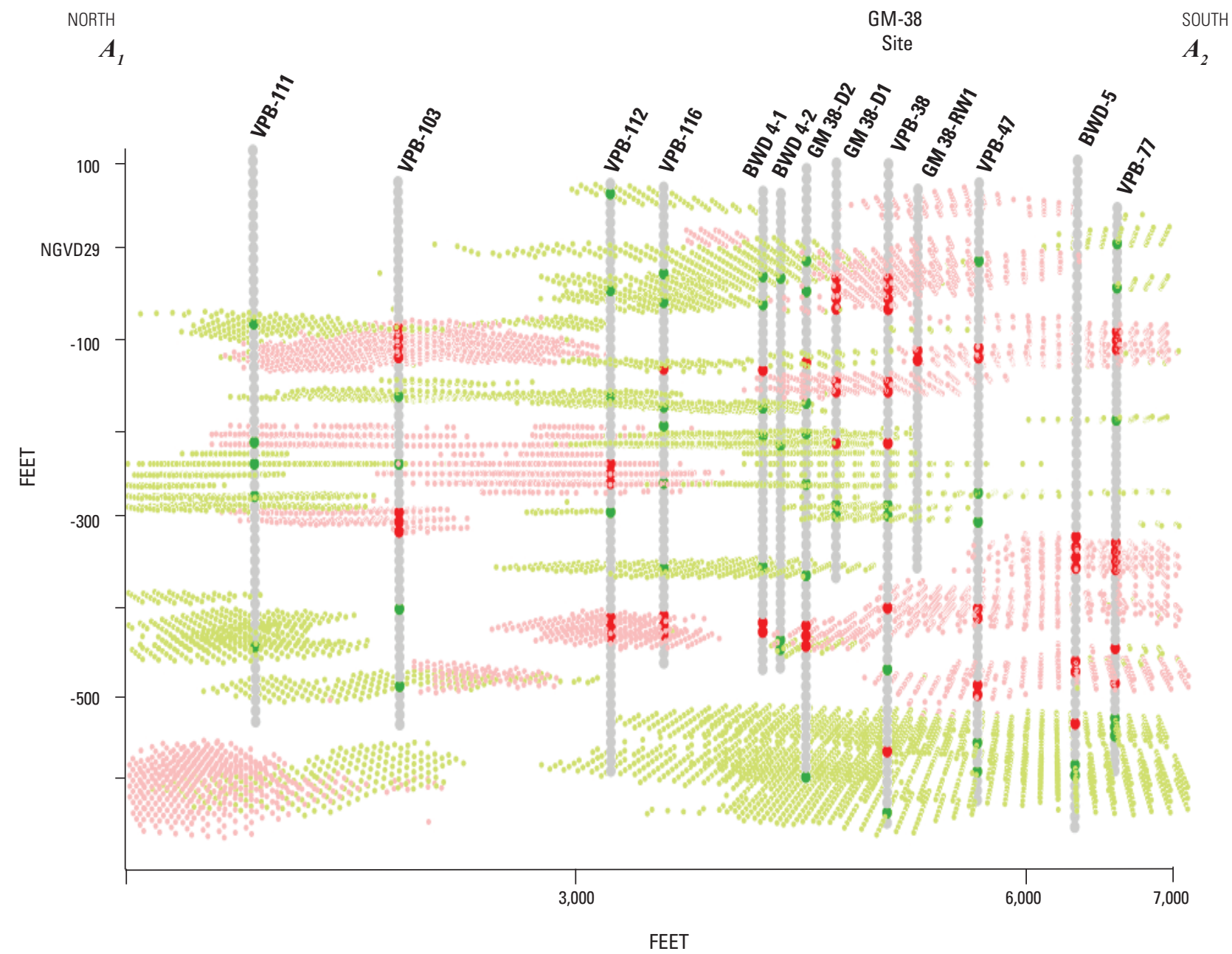

EXPLANATION

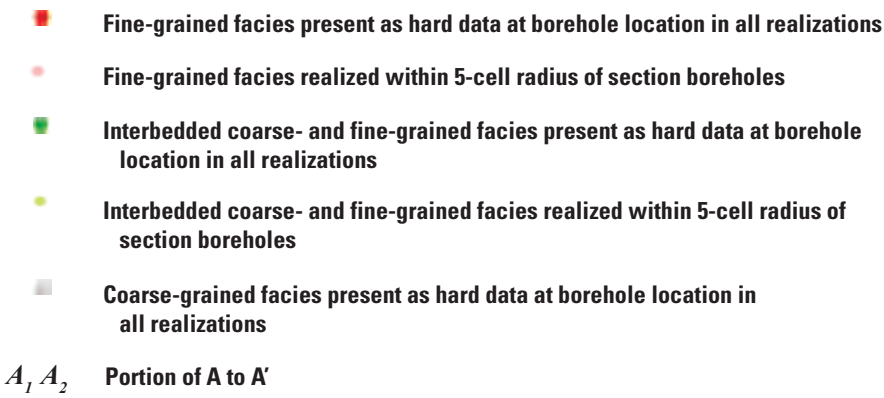

Figure 10. Conditional realization $A$ of Magothy aquifer heterogeneity along part of cross section $A-A^{\prime}$. (Location of section shown in figure 2) 


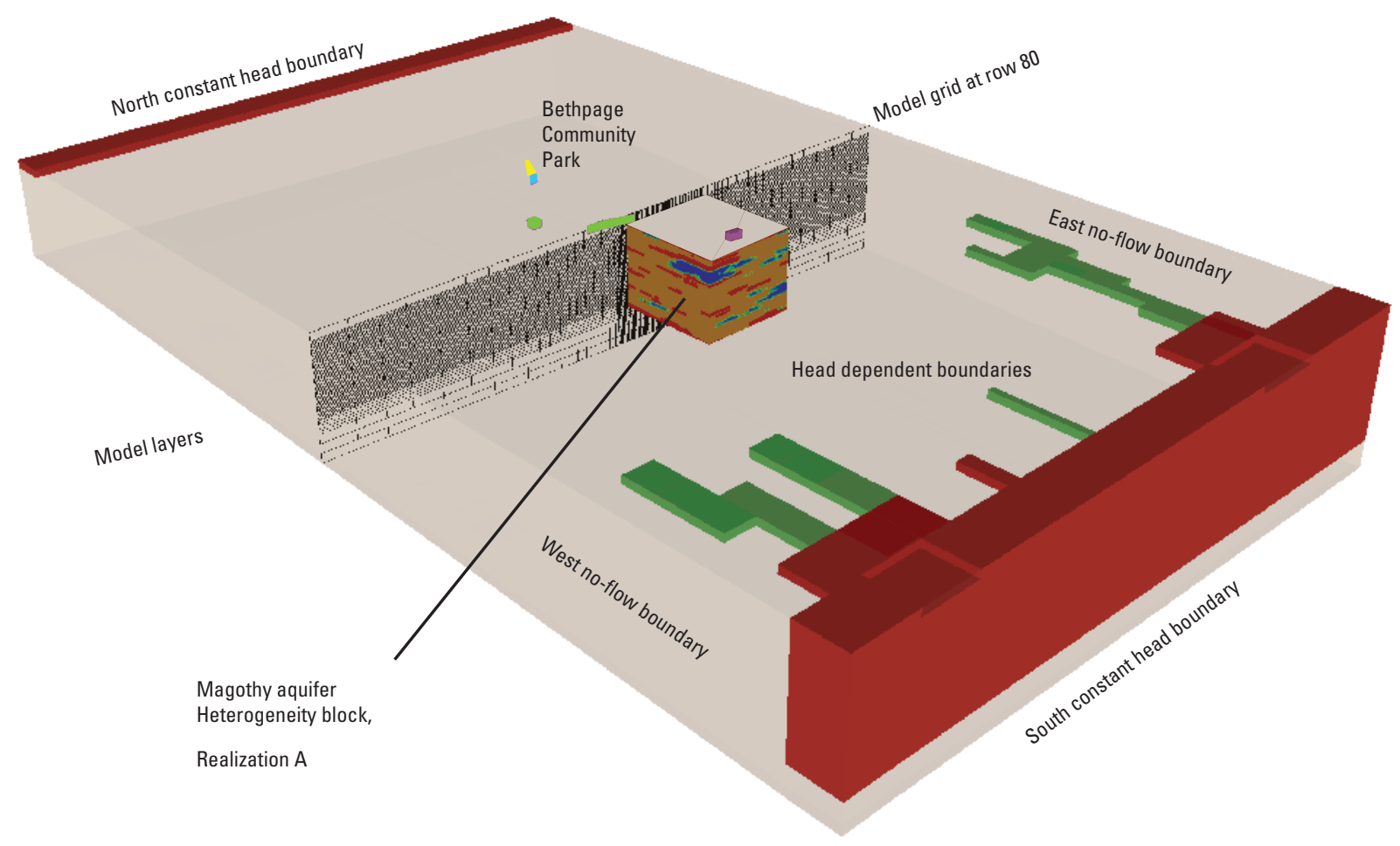

EXPLANATION

\begin{tabular}{|c|c|}
\hline Facies of heterogeneity block & Recharge basin receiving GM-38 outflow \\
\hline Coarse grained & Recharge basins receiving IRM outflow \\
\hline Interbedded coarse and fine grained & Recharge basins receiving ONCT outflow \\
\hline Fine grained & Bethpage Community Park \\
\hline
\end{tabular}

Figure 11. Conditional realization A within regional flow model with boundary conditions, model grid along row 80 , and other local features, Bethpage, New York. 

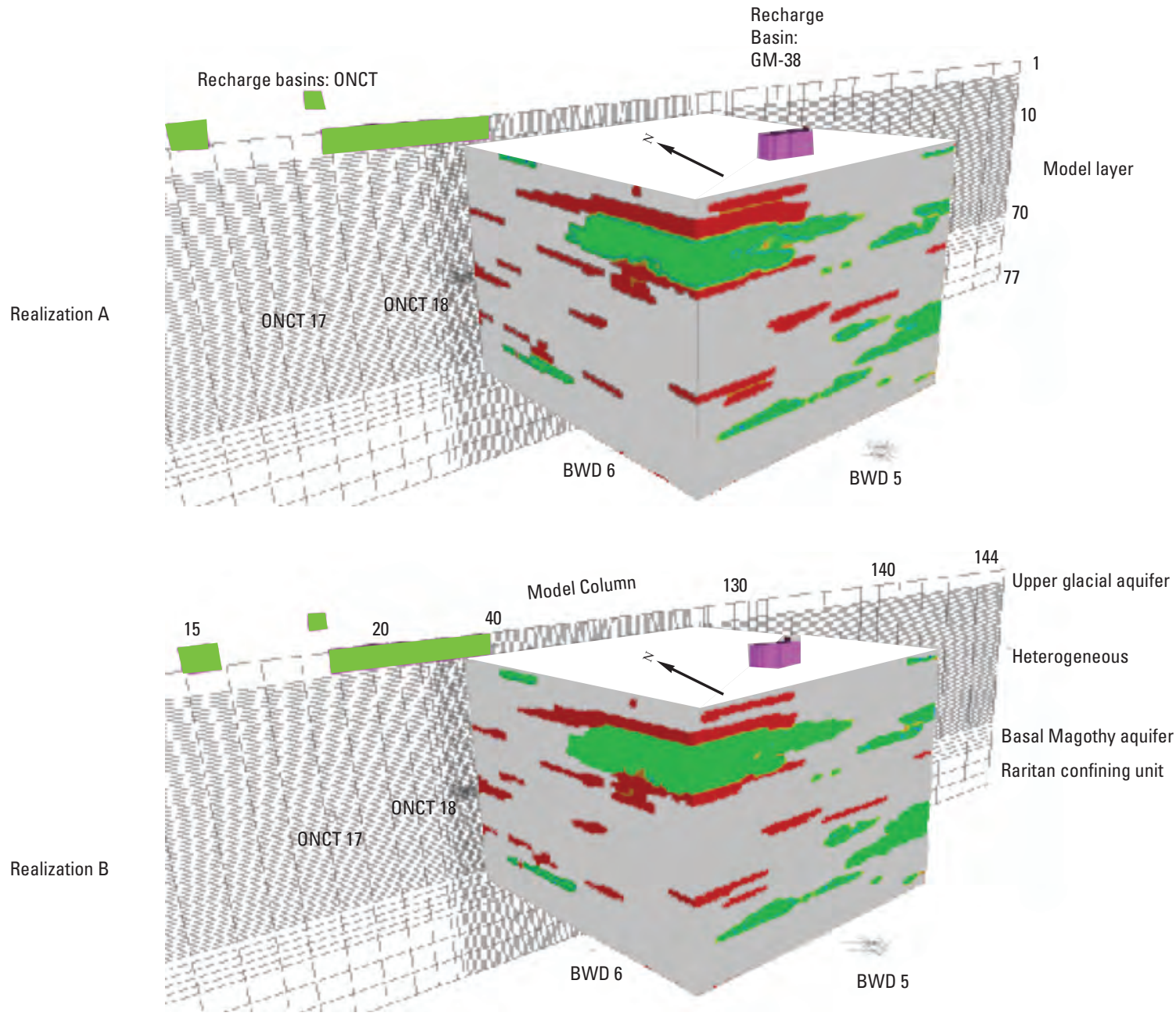

Realization C

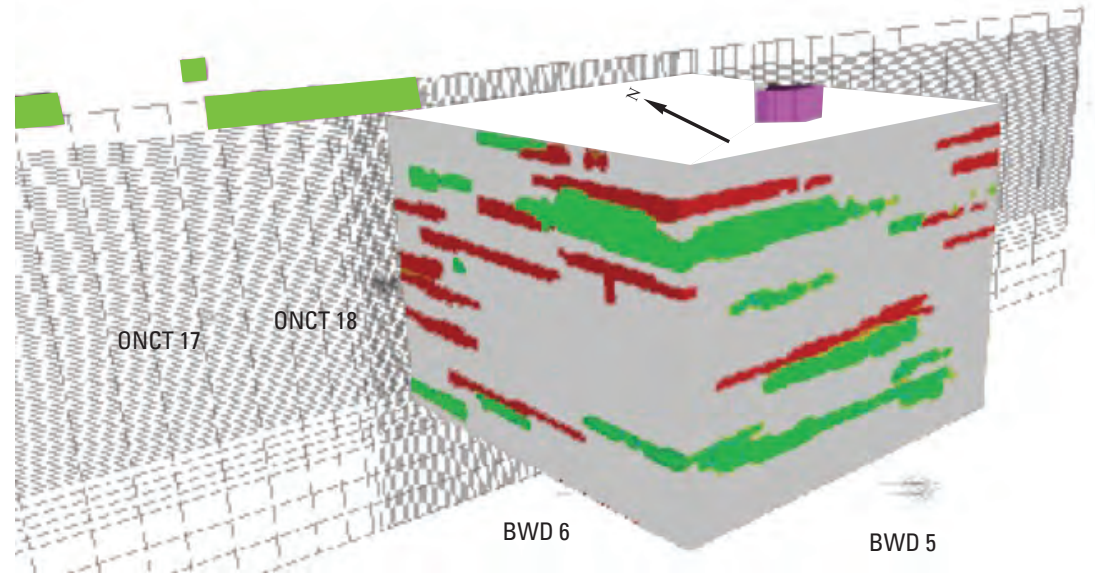

EXPLANATION

Facies of heterogeneity block

Coarse grained

Interbedded coarse and fine grained

Fine grained

Recharge basin receiving GM-38 outflow

Recharge basins receiving ONCT outflow

Figure 12. Magothy aquifer heterogeneity realizations $A, B$, and $C$ showing local features and hydraulic conductivity values, Bethpage, New York. (Locations of blocks shown in figure 11) 


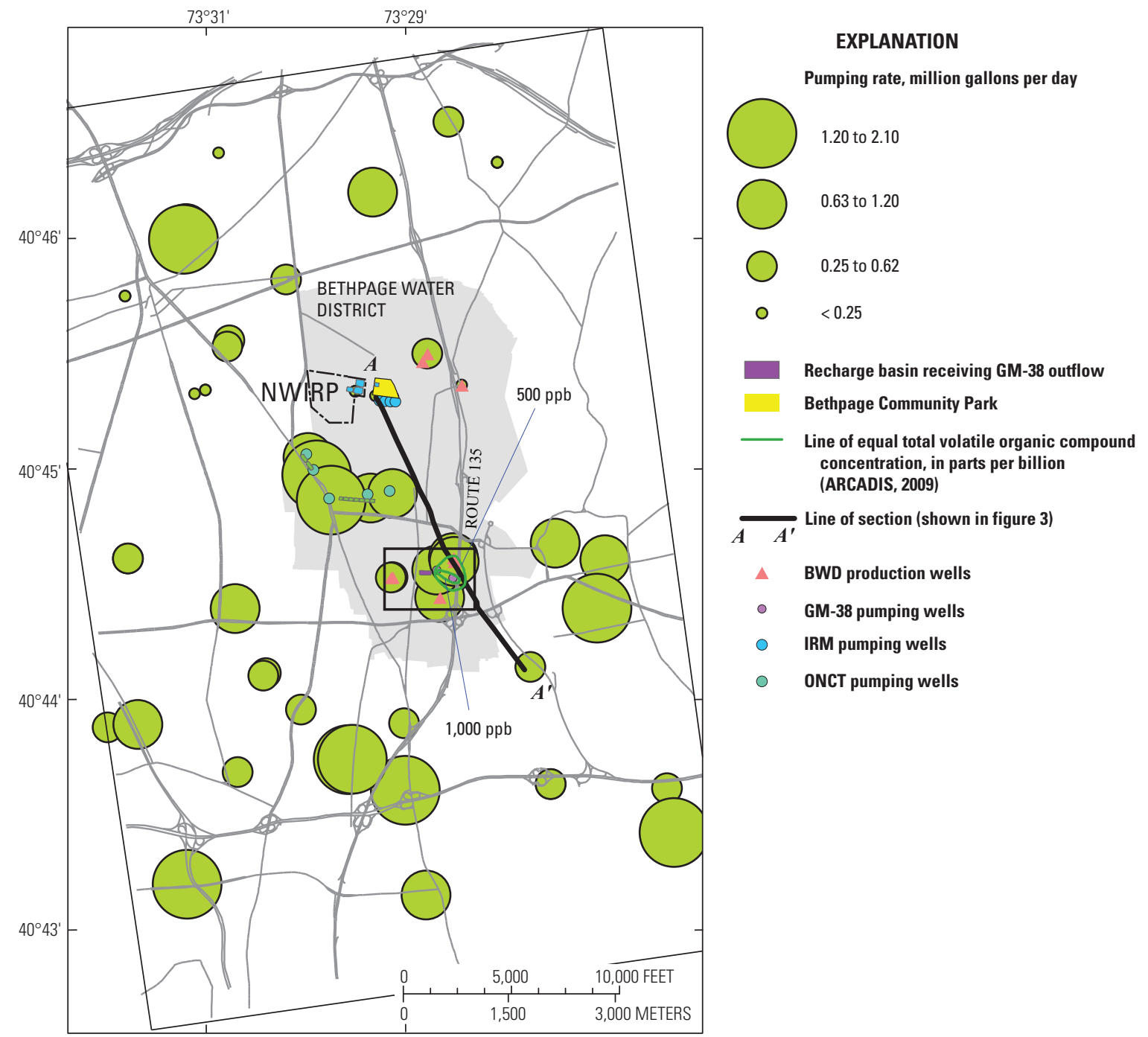

Base from U.S. Geological Survey digital data, 1:24,000

Lambert conformal conic projection, NAD83

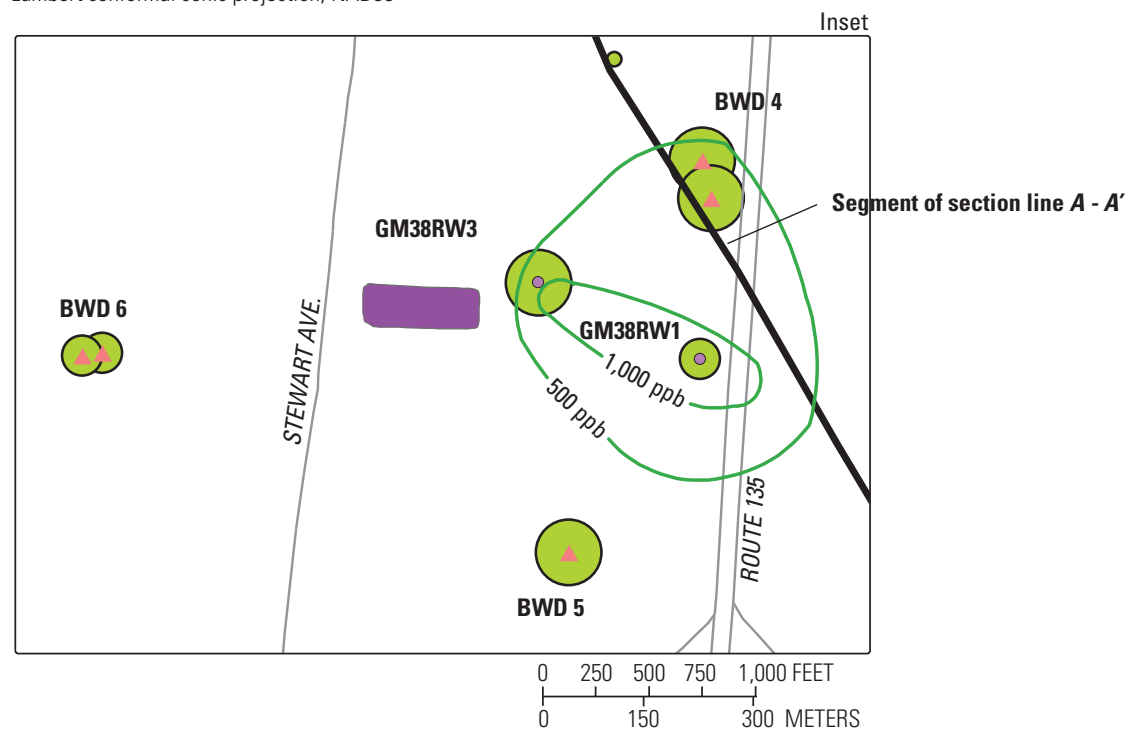

Figure 13. Specified present steady state conditions (2004-7) pumpage within regional model and GM-38 area (inset), and other local features, Bethpage, New York. 
period 2004 to 2007 and used to simulate alternatives of the NYSDEC operable unit 3 study area feasibility study (ARCADIS, 2010). The 2004-7 average rates are used for the ARCADIS (2010) present steady state conditions model, with three exceptions pertaining to more recent conditions in the vicinity of GM-38 (table 2). Representation of seasonal pumpage variation was beyond the scope of this study. Pumpage data from a 2013 aquifer test data were simulated separately to verify the present steady state conditions model described in this report and demonstrate the sensitivity of model results to certain transient-state changes, described in "Transient Modeling" section below.

Precipitation is the dominant source of water that recharges the groundwater system represented by the MODFLOW model (table 3). Factors affecting rates of recharge include: (1) spatial and temporal variations in precipitation, (2) permeability of surficial hydrogeologic units, (3) land-cover characteristics, and (4) discharge of domestic and industrial wastewater. Annual average precipitation is 42 inches (Miller and Fredrick, 1969). Under predevelopment conditions, about 50 percent of the precipitation reached the water table, mainly during the nongrowing season (Seaburn and Aronson, 1974; McClymonds and Franke (1972). Under present conditions, recharge is mainly from infiltration of precipitation through unpaved areas (fig. 14), infiltration through recharge basins, and leaky underground pipes. At the southern boundary of the model, stormwater runoff is routed into the headwaters of south-flowing stream channels. Model recharge zones are shown in figure 15 as follows: (a) average conditions (green), (b) recharge basins (yellow to red depending on the ratio of recharge basin area to model cell), and (c) zone of runoff to streams (blue). Within the recharge basins zone, natural average conditions recharge is increased by a calibration parameter multiplied by the ratio of recharge basin area to model cell. Within the stream runoff zone, natural average conditions recharge is decreased by a calibration parameter applied uniformly through the zone. In addition to these zones, recharge is specified at selected recharge basins, including discharge associated with the GM-38 water treatment plant. Integrated over the regional model area, the present conditions recharge rate is about 13 percent greater than an equivalent predevelopment rate of 21 inches per year (equivalent to 5,634,000 cubic feet per day applied to the regional model area).

Representation of plume source loading mechanisms such as contaminant inflow was beyond the scope of the study. Simulations described in this report do not characterize the historical development of the plume.

\section{Steady State Flow Model Results}

Simulated steady state flow fields are generally oriented from north to south with zones of convergence at pumping wells, zones of divergence at recharge basins, and some refraction due to the presence of confining beds. There is also a downward component due to the entry of groundwater
Table 2. Difference in pumping rates between ARCADIS (2010) and U.S. Geological Survey present steady state conditions models for selected wells at site GM-38, Bethpage, New York.

[Pumping rate is expressed in gallons per minute; USGS, U.S. Geological Survey]

\begin{tabular}{ccc}
\hline $\begin{array}{c}\text { Well } \\
\text { (2010) }\end{array}$ & ARCADIS & USGS \\
\hline GM-38-RW1 & 800 & 700 \\
GM-38-RW3 & 300 & 220 \\
BWD 6-2 & 0 & 500 \\
\hline
\end{tabular}

Table 3. Water balance simulated by U.S. Geological Survey present steady state conditions model of Bethpage, New York (model domain shown in figure 5).

\begin{tabular}{|c|c|}
\hline Model component & $\begin{array}{c}\text { Value } \\
\text { (cubic feet per day) }\end{array}$ \\
\hline \multicolumn{2}{|c|}{ Inflow } \\
\hline Constant head & 245,802 \\
\hline Specified recharge basins & 878,625 \\
\hline Recharge from precipitation & $6,388,687$ \\
\hline Total inflow & $7,513,114$ \\
\hline \multicolumn{2}{|c|}{ Outflow } \\
\hline Constant head & $2,299,059$ \\
\hline Drains & 756,818 \\
\hline Wells & $4,457,454$ \\
\hline Total outflow & $7,513,330$ \\
\hline
\end{tabular}

recharge from precipitation. The downward component mainly occurs in the northern part of the model, which is just south of a regional flow divide between waters that ultimately discharge to either the northern or southern shores of Long Island (fig. 1). Figures 16 and 17 show contours of head for model layer 30, column 107, and row 176, which intersect the screen zone of GM-38-RW1. In the row and column sections, the hydraulic influence of BWD 4 to the north and west is noticeable, and in the column section, the hydraulic influence of BWD5 is also noticeable to the south of GM-38-RW1.

\section{Transient Modeling}

The hydrologic response during an aquifer test reported by Tetra Tech (2013) was modeled in transient state with 13 stress periods to verify the current USGS present steady state conditions models with alternative realizations of Magothy aquifer heterogeneity and to demonstrate the sensitivity of model results to certain transient-state changes. 


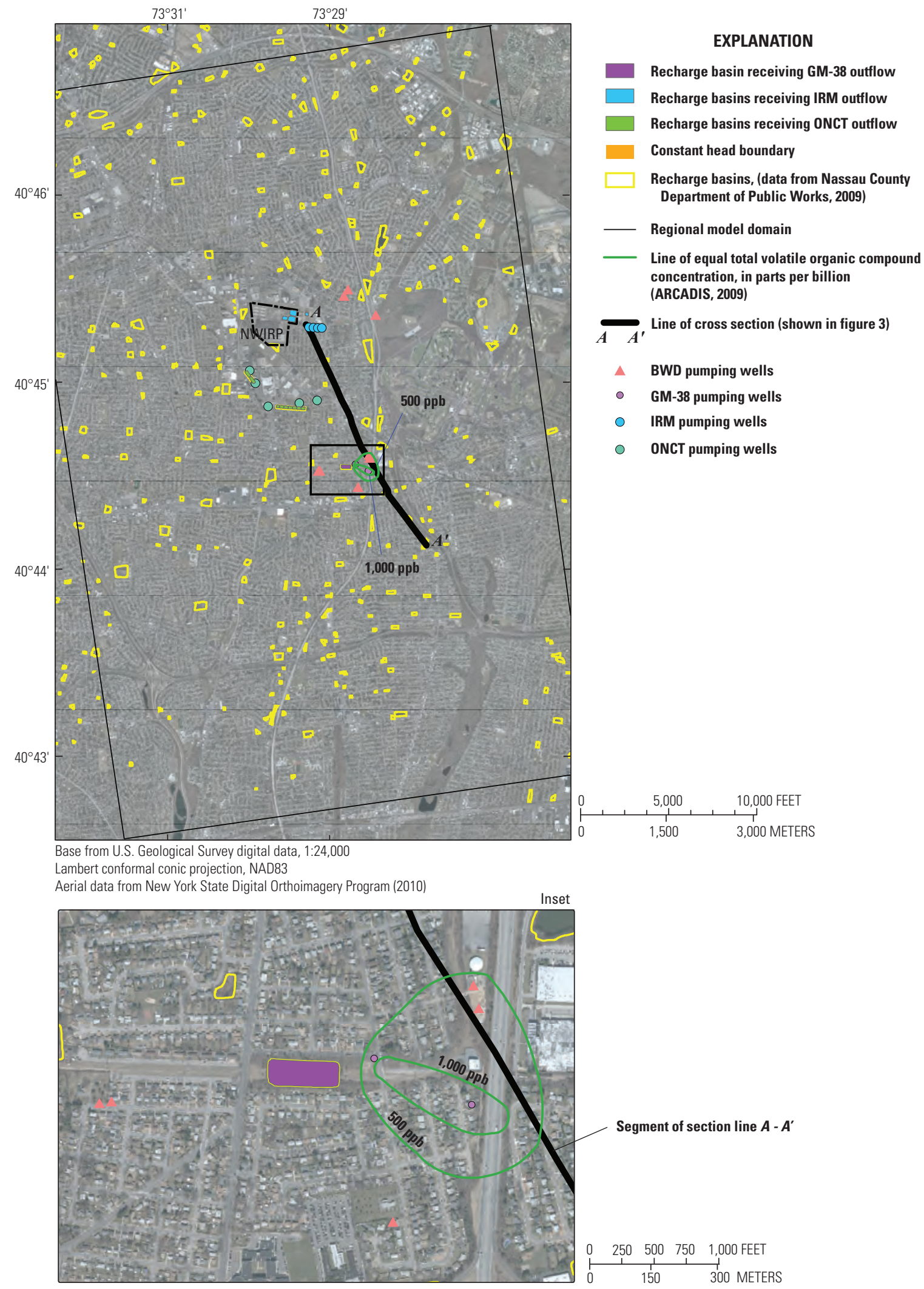

Figure 14. Locations of recharge basins and other local features in the regional model and the GM-38 area (inset), Bethpage, New York. 


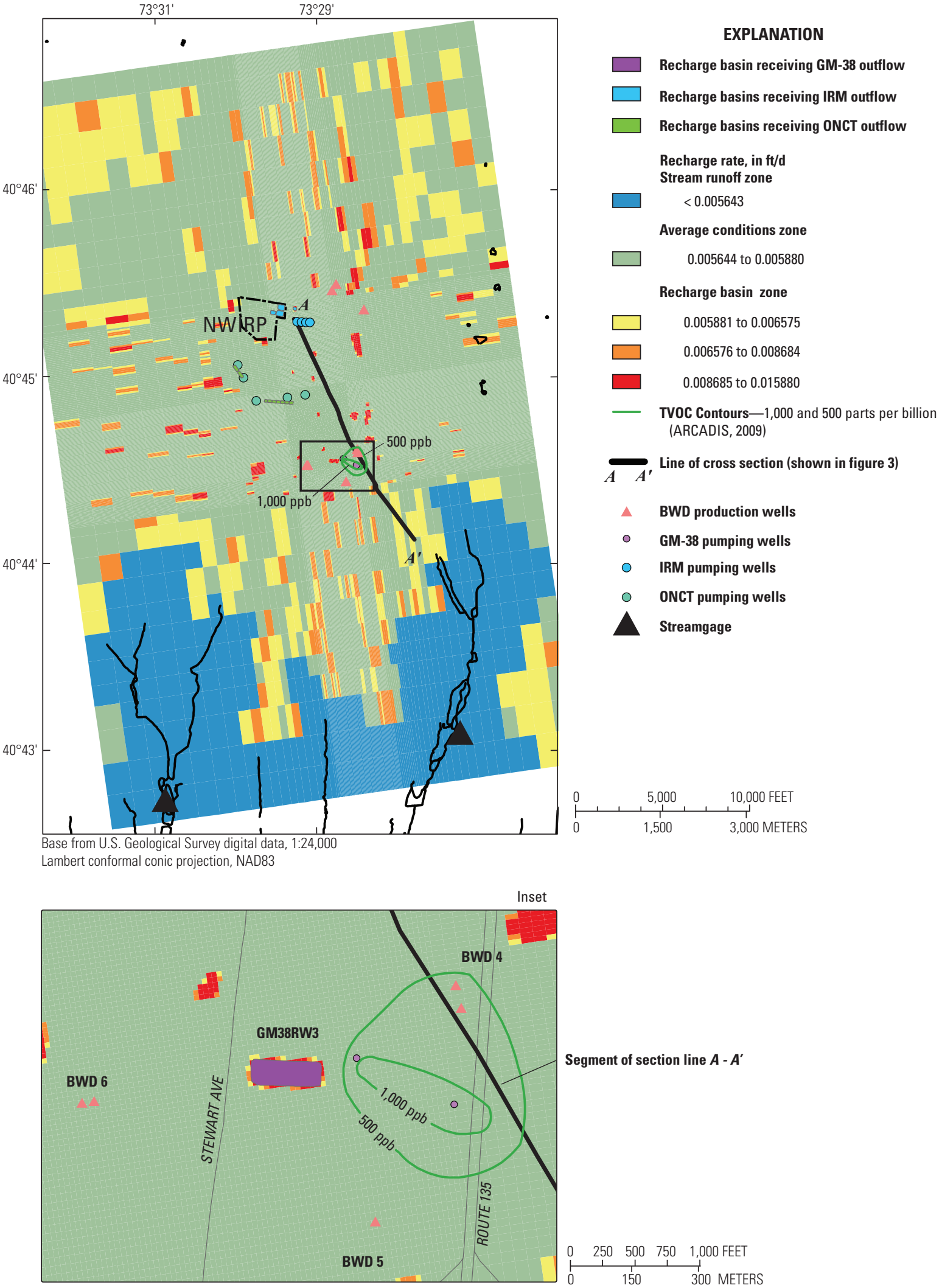

Figure 15. Specified cell-by-cell recharge rates and other local features in the regional model and the GM-38 area (inset), Bethpage, New York. 

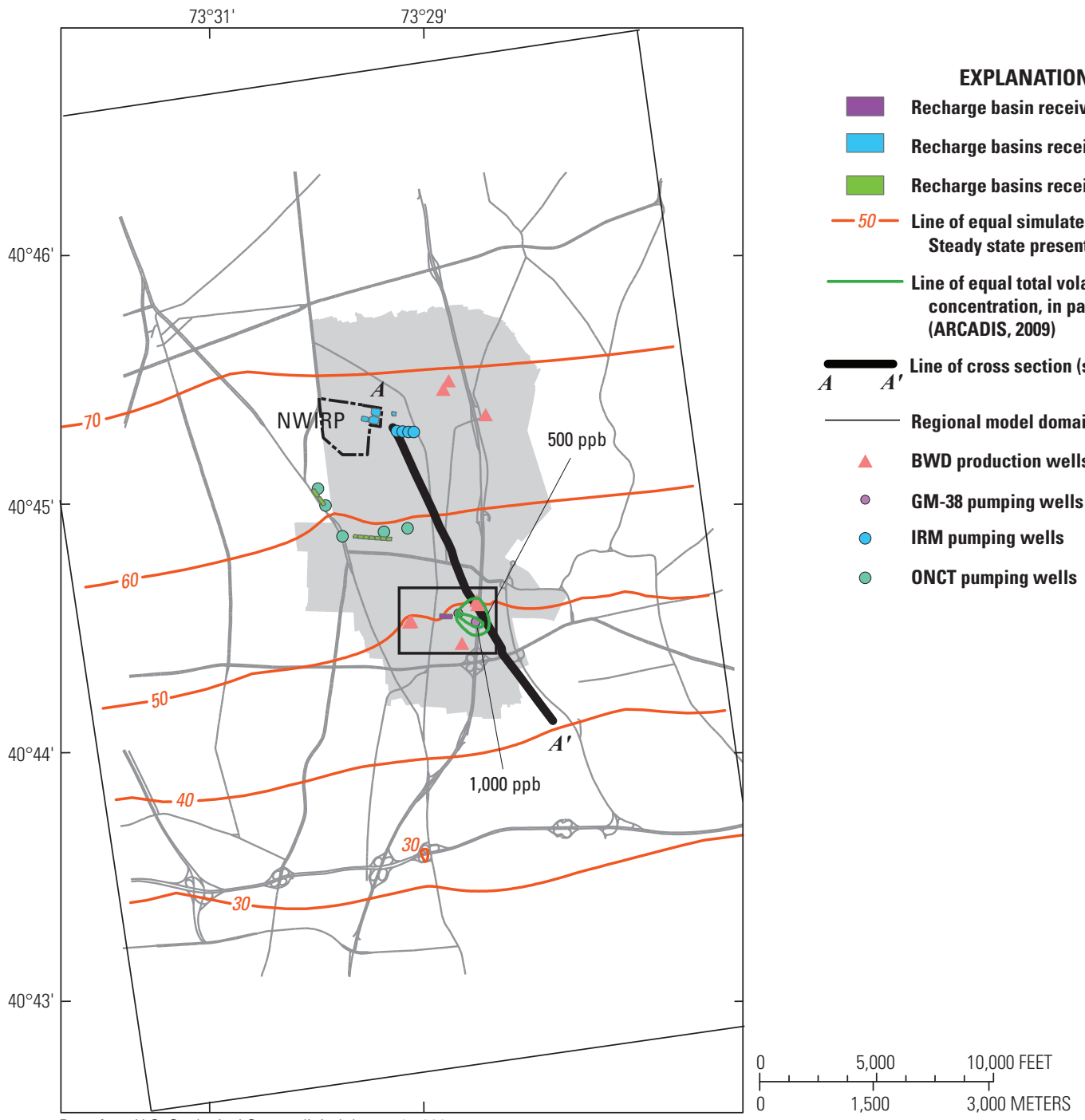

Base from U.S. Geological Survey digital data, 1:24,000

Lambert conformal conic projection, NAD83

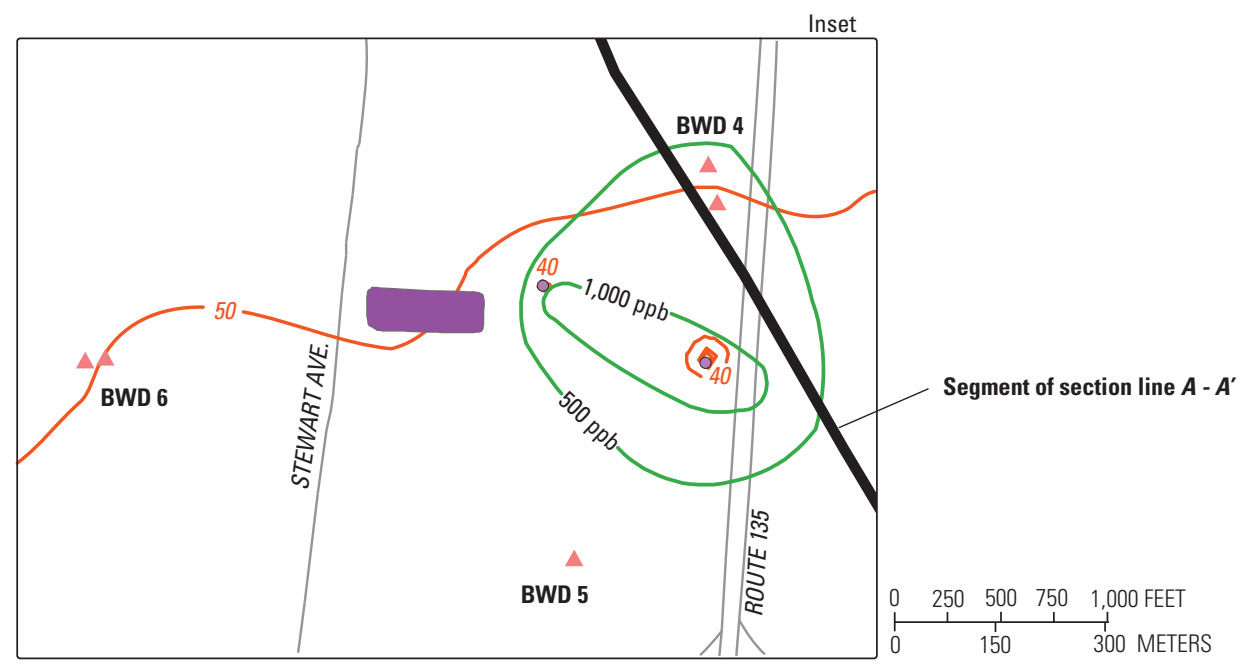

Figure 16. Simulated present conditions steady state heads at model layer 30 (screen zone of GM-38-RW1) and other local features in regional model and GM-38 area (inset), Bethpage, New York. 
NORTH

SOUTH

Row along column 107

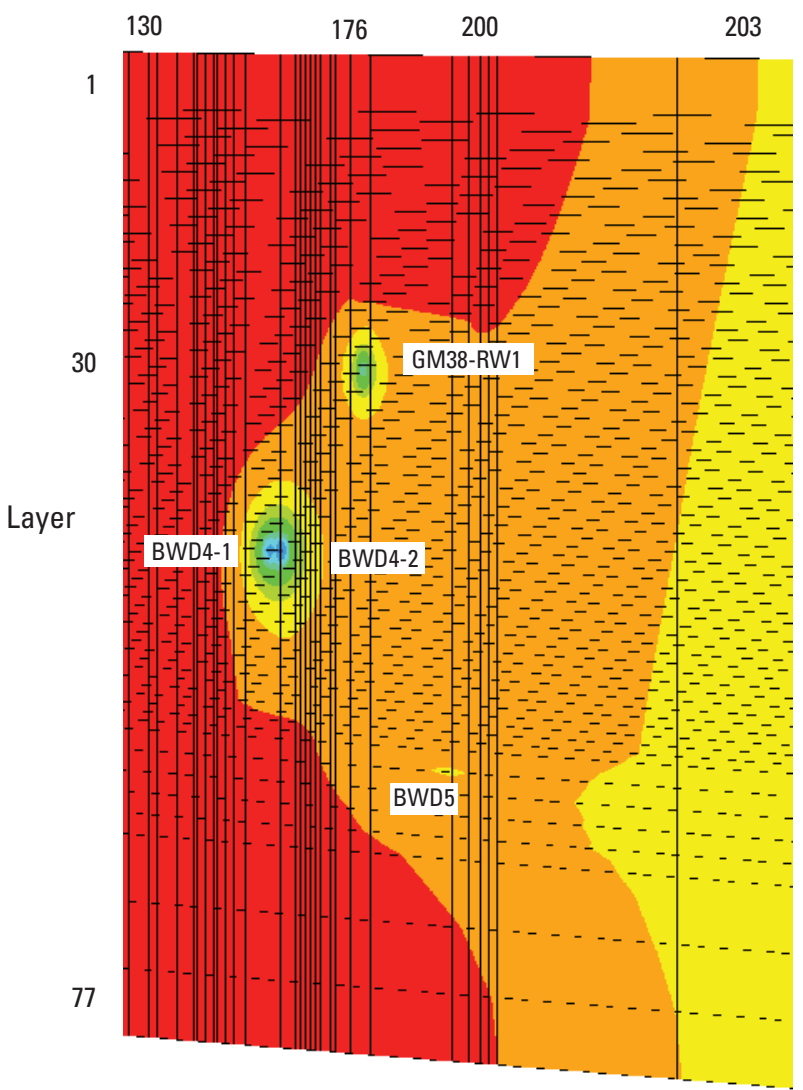

WEST

20

107

130

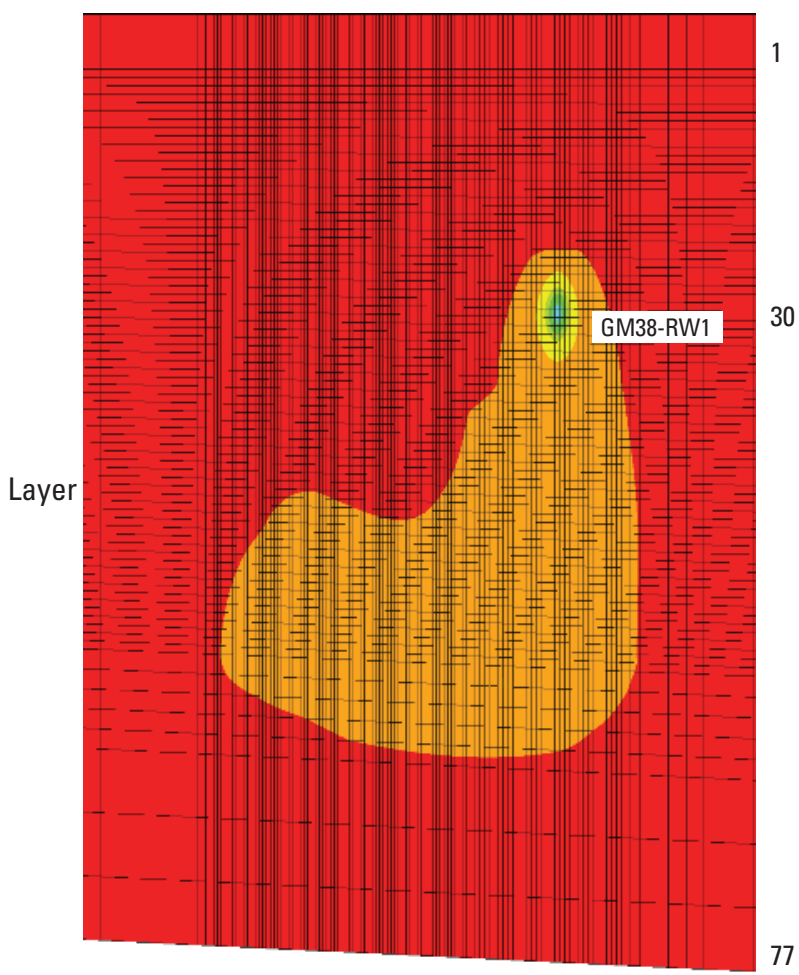

$\underbrace{0}_{0} \stackrel{300}{1,000} \underbrace{2,000 ~ F E E T ~}_{1}$

Column along row 176

\section{EXPLANATION}

Simulated head, 3 foot color interval, steady-state present conditions, NGVD 29

\begin{tabular}{|l|l|l|}
\hline 50 to $>47$ & 41 to $>38$ & 32 to $>29$ \\
\hline 47 to $>44$ & 38 to $>35$ & 29 to $>26$ \\
\hline 44 to $>41$ & 35 to $>32$ & 26 to $>23$
\end{tabular}

Figure 17. Simulated present conditions steady state heads at model row 176 and column 107 (screen zone of GM-38-RW1), Bethpage, New York. 
Model calibration and sensitivity analysis are discussed in "Model Calibration and Sensitivity Analysis" below. During the aquifer test, pumpage rates of GM-38-RW1 and GM-38-RW3 were controlled with pumping and recovery periods of significant duration, while other production wells in the vicinity had various uncontrolled pumping and recovery periods. The history of pumpage during the aquifer test is shown in figure 18 and table 4 . Stress periods were specified to represent variations in pumping and a steadystate present conditions period preceded the transient stress periods. During the steady state prior to the aquifer test, all wells are on. At the start of the aquifer test wells GM-38RW1, GM-38-RW3, BWD4-1, and BWD4-2 are turned off. The starting time of this initial transient state period is March 29, 2013 at 6:00 Eastern Standard Time. During the following stress periods, the GM-38 wells are turned on and off in controlled testing patterns, while the Bethpage wells are turned on and off according to normal operation. In the final stress period, all wells are turned on except for BWD4-1 and BWD4-2. The end of the final transient state period is April 9, 2013 at 0:00 EST.

\section{Model Calibration and Sensitivity Analysis}

Model calibration is discussed in the following sections, together with sensitivity of computed model responses to changes in parameter values that reflect plausible parameter uncertainty.

Hydraulic conductivity and recharge parameters were calibrated using water-level and streamflow data and the USGS calibration software UCODE_2005 (Poeter and others, 2005), applied to the present steady state conditions MODFLOW model (heterogeneity realization A), with final calibrated parameter values similar to those given in ARCADIS (2010) and TetraTech (2013). After calibration the steady state model was used to delineate ZOCs. In addition to UCODE_2005 calibration, qualitative comparison of transient state models with water-level data collected by Tetra Tech (2013) was also done. The ARCADIS and USGS models are both constructed and calibrated using the NGVD29 sea level datum.

The UCODE_2005 calibration water-level data (locations shown in figure 19) were mainly collected by ARCADIS in 2006 (ARCADIS, 2010) and assumed to represent present

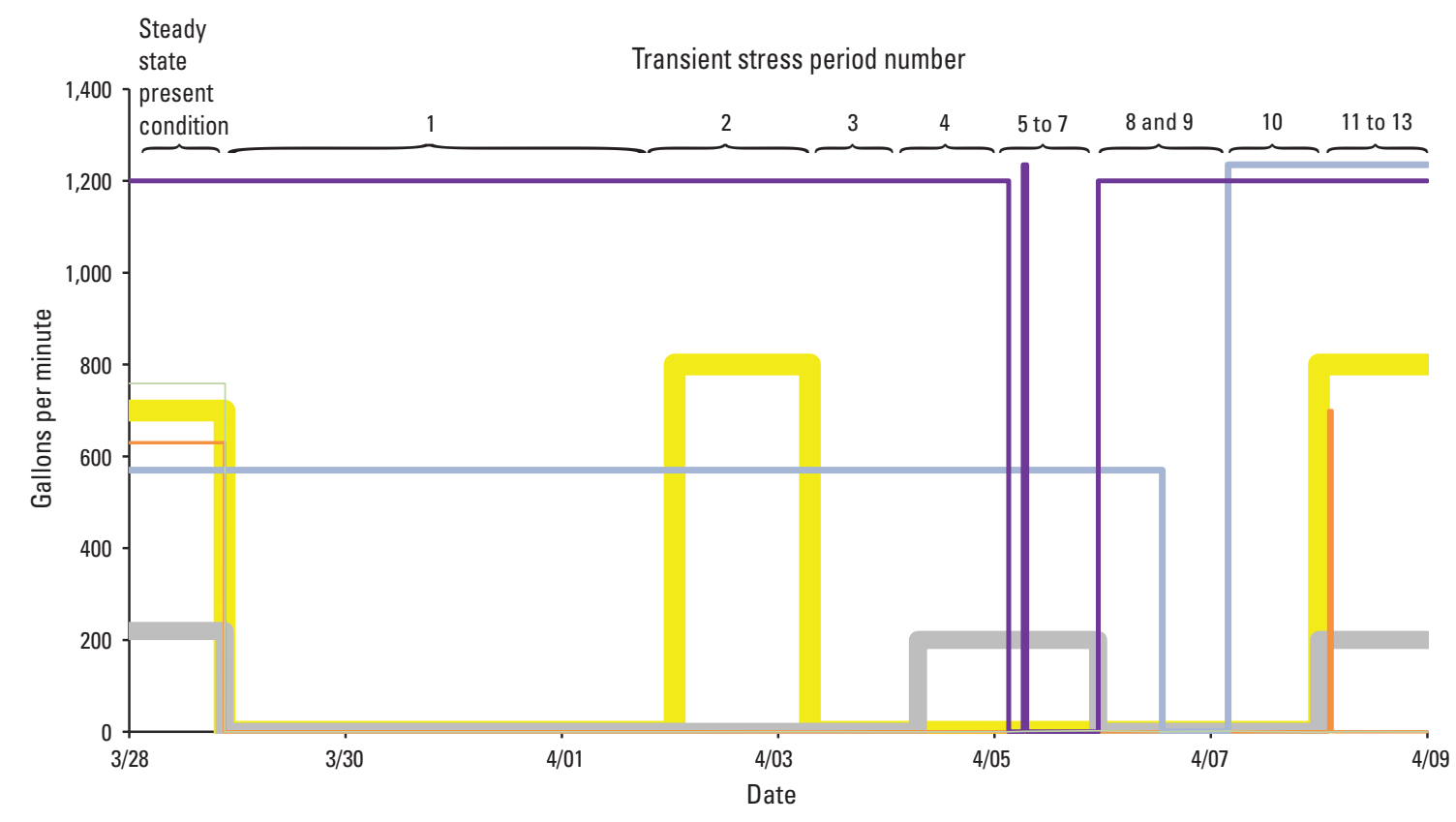

EXPLANATION

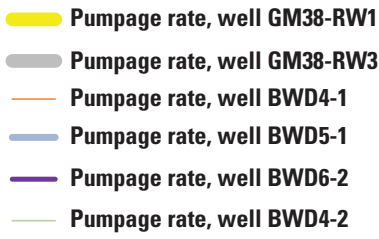

Figure 18. Modeled history of pumpage rates during aquifer test, March to April 2013, Bethpage, New York. (Well locations shown on figure 13) 
Table 4. Pumping of wells during transient stress periods, Bethpage, New York.

\begin{tabular}{cccccccc}
\hline $\begin{array}{c}\text { Stress } \\
\text { Period }\end{array}$ & GM-38-RW1 & GM-38-RW3 & BWD4-1 & BWD4-2 & BWD5-1 & BWD6-2 & $\begin{array}{c}\text { Duration, } \\
\text { minutes }\end{array}$ \\
\hline $\begin{array}{c}\text { (initial condition) } \\
1\end{array}$ & On & On & On & On & On & On & $\begin{array}{c}\text { Infinite } \\
\text { (steady state) }\end{array}$ \\
2 & Off & Off & Off & Off & On & On & 5,992 \\
3 & On & Off & Off & Off & On & On & 1,800 \\
4 & Off & Off & Off & Off & On & On & 1,440 \\
5 & Off & On & Off & Off & On & On & 1,208 \\
6 & Off & On & Off & Off & On & Off & 193 \\
7 & Off & On & Off & Off & On & On & 47 \\
8 & Off & On & Off & Off & On & Off & 952 \\
9 & Off & Off & Off & Off & On & On & 852 \\
10 & Off & Off & Off & Off & Off & On & 875 \\
11 & Off & Off & Off & Off & On & On & 1,213 \\
12 & On & On & Off & Off & On & On & 129 \\
13 & On & On & On & Off & On & On & 43 \\
\hline
\end{tabular}

steady state conditions. Use of ARCADIS observations to approximate present steady state conditions may be evaluated by inspecting recent hydrographs collected during the GM-38 aquifer test (list of wells given in table 5, from Tetra Tech, 2013) and by inspecting long-term hydrographs of USGScollected data. Figure 20 is a hydrograph of observation well N1259 collected by USGS from 1961 to 2013, with the water level used for present conditions steady state model calibration. Water-level fluctuations in well N1259 and others like it around Long Island are discussed in detail in Busciolano (2005) and Misut (2011). Two of the main influences on water-level changes are prolonged drought during the 1960s and the large-scale sewering project of the 1980s. 2006 was the beginning of a relatively stable condition continuing to the present (2012). As indicated in figure 20, average water levels from 2006 to 2012 are similar to averages from 1961 to 2013 and from 1980 to 2008.

Calibration streamflow data (gaging station locations shown in figure 5, data available at http://nwis.waterdata. usgs.gov/ny/nwis/sw) was averaged from 1980 to 2008 by Rozell (2010) to represent present condition average flow rates. Percent of total baseflow discharge to streams, shown in figure 21, trended downward from the 1960s to 1980 due to urbanization, but appears to have stabilized through the present. The large-scale sewering project of the 1980's likely resulted in decreased streamflow; however, because the overall period 1980 to 2008 includes significant periods of aboveaverage rainfall, both water levels and baseflow discharges represent a long-term present condition. Mean total discharge at gages in cubic feet per second $\left(\mathrm{ft}^{3} / \mathrm{s}\right)(1980-2008)$ for the model stream channels are as follows: Massapequa Creek: $5.12 \mathrm{ft}^{3} / \mathrm{s}$, and Bellmore Creek $3.71 \mathrm{ft}^{3} / \mathrm{s}$. Discharge to Seaford Creek is simulated with the MODFLOW DRN package but not subject to UCODE-2005, due to lack of field observation. Model calibration streamflow residuals are weighted such that they represent about 5 percent of the total UCODE_2005 objective function including water-level residuals.

During UCODE_2005 calibration and parameter estimation, horizontal and vertical hydraulic conductivity and recharge parameters were initially set to ARCADIS (2010) model values where available and allowed to vary within the ranges given in table 6. UCODE_2005 finds parameter values that minimize an objective function and thereby optimize model fit to observed data. The objective function utilized by UCODE_2005 to estimate parameter values minimizes the sum of squared residuals (simulated minus observed) and may be divided by the number of residuals to calculate the root mean square error (RMSE). In addition, UCODE calculates Composite Scaled Sensitivity (CSS) of parameters (fig. 22) and the degree of correlation of parameters. CSS may be used to compare the amount of information provided by different types of parameters, and model simulation results will be more sensitive to parameters with large CSS. This analysis is available as part of the report model digital archive, available online. According to the CSS, the model results are most sensitive to the background recharge rate, the horizontal hydraulic conductivity of the Magothy aquifer coarse-grained facies, horizontal hydraulic conductivity of the upper glacial aquifer, vertical hydraulic conductivity of the Magothy aquifer coarse-grained facies, horizontal hydraulic conductivity of the basal Magothy aquifer zone, and the recharge basin factor, which is added to the background recharge rate. Model results are least sensitive to parameters related to the finegrained facies of the Magothy aquifer are among the least sensitive with respect to minimizing the objective function, likely due to: (a) the discontinuity of fine-grained beds, and 


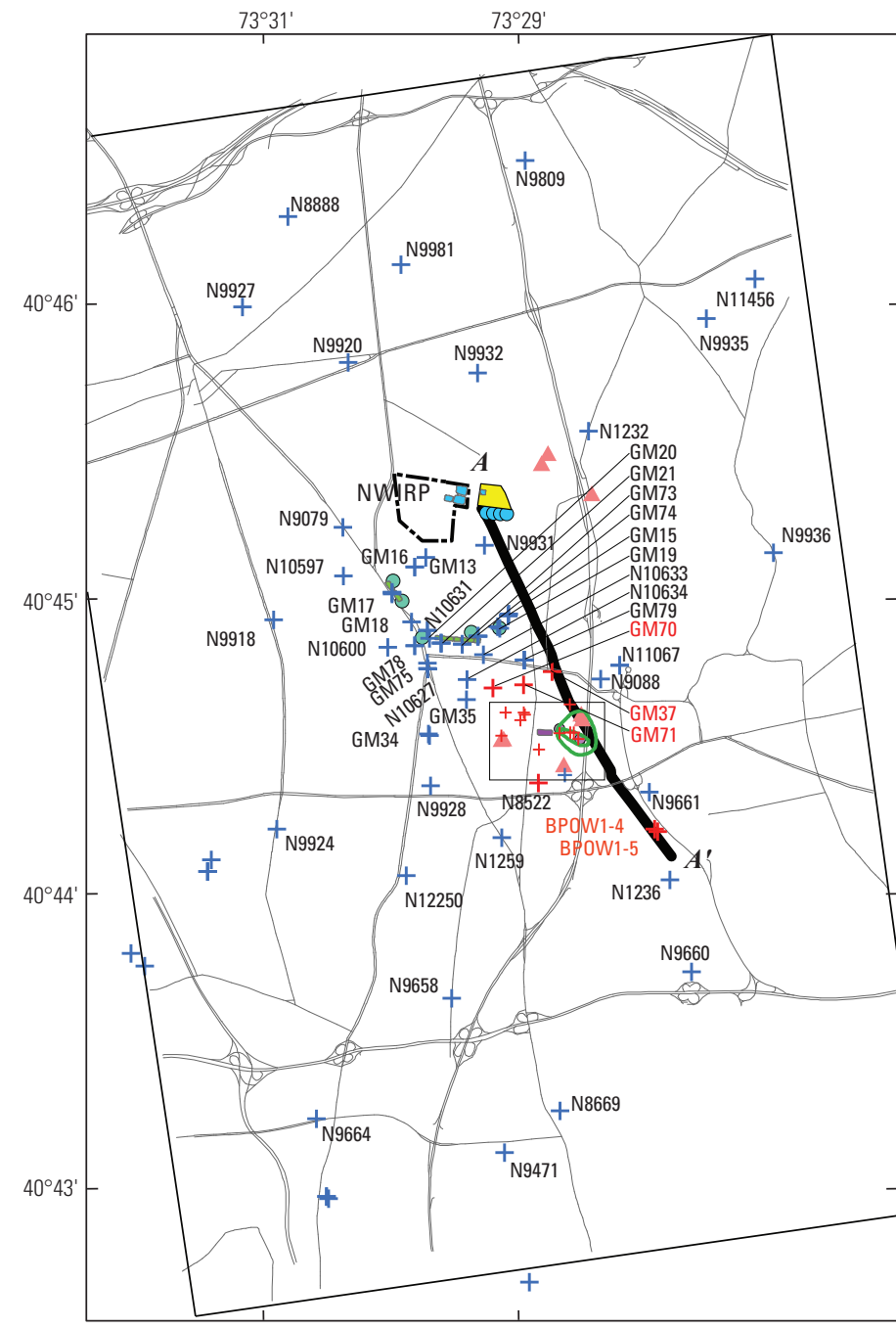

\section{EXPLANATION}

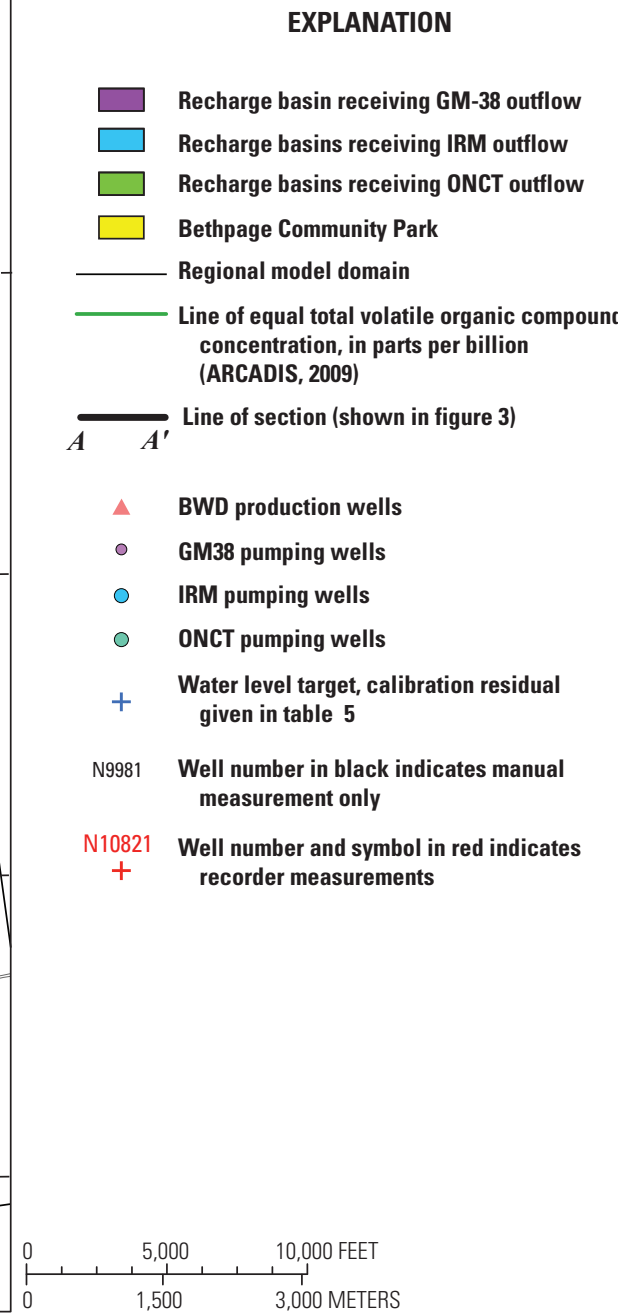

Base from U.S. Geological Survey digital data, 1:24,000

Lambert conformal conic projection, NAD83

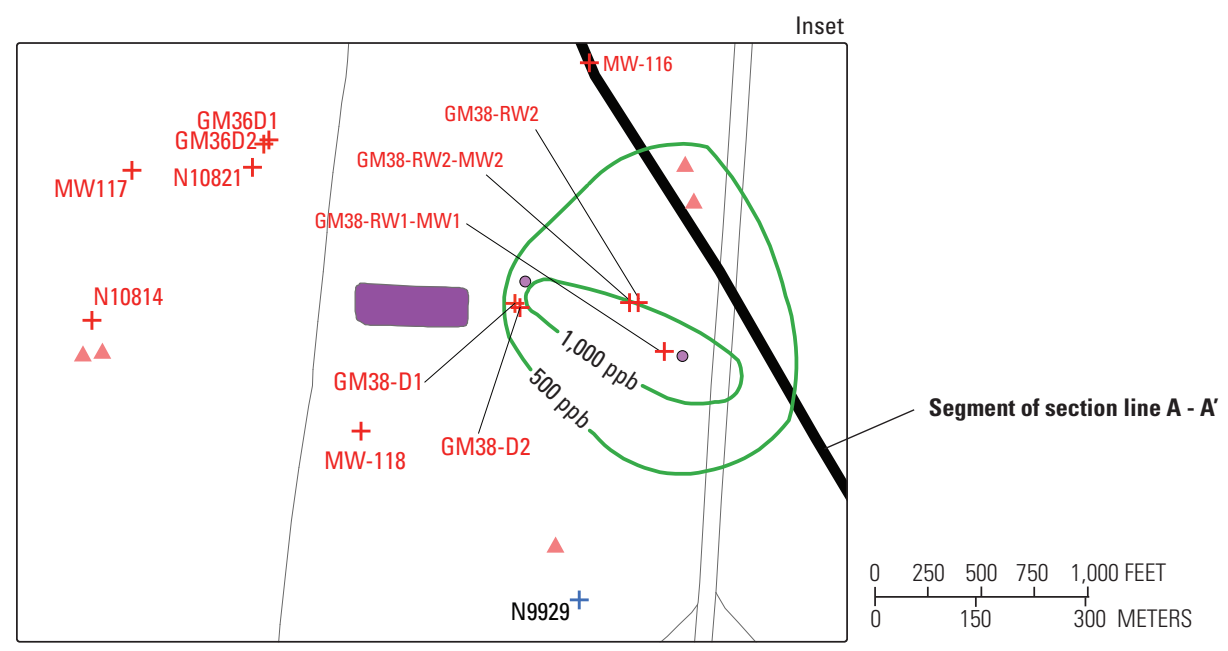

Figure 19. Observation wells monitored for regional model or GM-38 area and other local features in regional model and GM-38 area (inset), Bethpage, New York. (Observation wells from ARCADIS, 2010 and Tetra Tech, 2013) 
Table 5. Observation wells monitored for the GM-38 capture zone study, Bethpage, New York.

[From Tetra Tech (2013); locations shown in figure 19; NAVD88, North American Vertical Datum of 1988; <, less than; >, greater than]

\begin{tabular}{|c|c|c|}
\hline Well & $\begin{array}{c}\text { Top of casing } \\
\text { (feet above NAVD88) }\end{array}$ & $\begin{array}{c}\text { Screen interval } \\
\text { (feet below ground surface) }\end{array}$ \\
\hline \multicolumn{3}{|c|}{ Depth $<300$ feet } \\
\hline GM-36D & 91.63 & $204-214$ \\
\hline N10821 & 91.58 & $52-56$ \\
\hline N8522 & Unknown & $105-125$ \\
\hline N10814 & Unknown & $68-72$ \\
\hline \multicolumn{3}{|c|}{ Depth 300-600 feet } \\
\hline GM-38D & 91.75 & $320-340$ \\
\hline GM-38D2 & 91.56 & $475-495$ \\
\hline $\begin{array}{l}\text { GM-38- } \\
\text { RW2 }\end{array}$ & Unknown & $440-510$ \\
\hline GM-36D2 & 91.60 & $520-540$ \\
\hline RW1-MW1 & 85.87 & $395-435$ \\
\hline RW2-MW2 & 90.75 & $470-510$ \\
\hline GM-71D2 & 98.45 & $444-464$ \\
\hline GM-37D2 & 97.17 & $370-390$ \\
\hline GM-70D2 & 99.58 & $310-330$ \\
\hline BPOW 1-4 & 44.54 & $340-400$ \\
\hline MW-116 & 93.58 & $570-590$ \\
\hline \multicolumn{3}{|c|}{ Depth $>600$ feet } \\
\hline MW-117 & 94.80 & $737-757$ \\
\hline MW-118 & 85.53 & $713-738$ \\
\hline BPOW 1-5 & 44.61 & $600-650$ \\
\hline BPOW 1-6 & 44.92 & $700-750$ \\
\hline
\end{tabular}

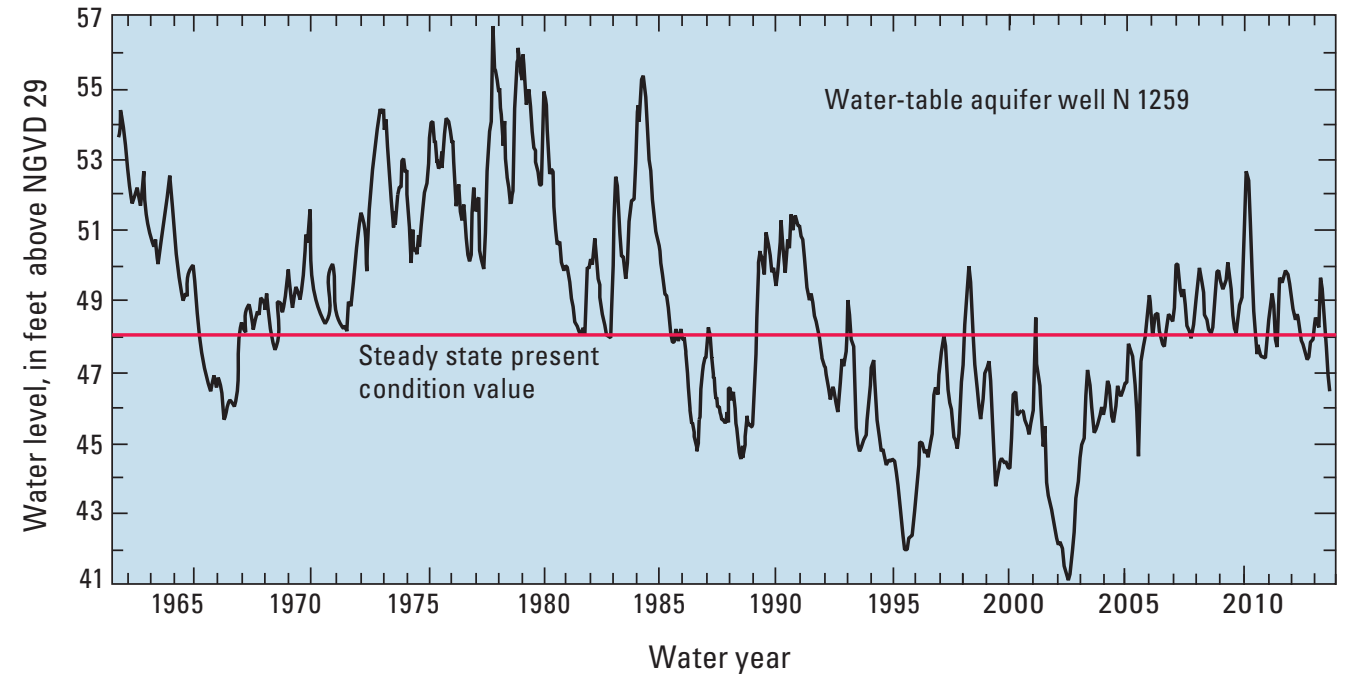

Figure 20. Head time series of U.S. Geological Survey well N1259 from 1961 to 2013 and presentconditions steady state present average, Bethpage, New York. (Well location shown in figure 19) 


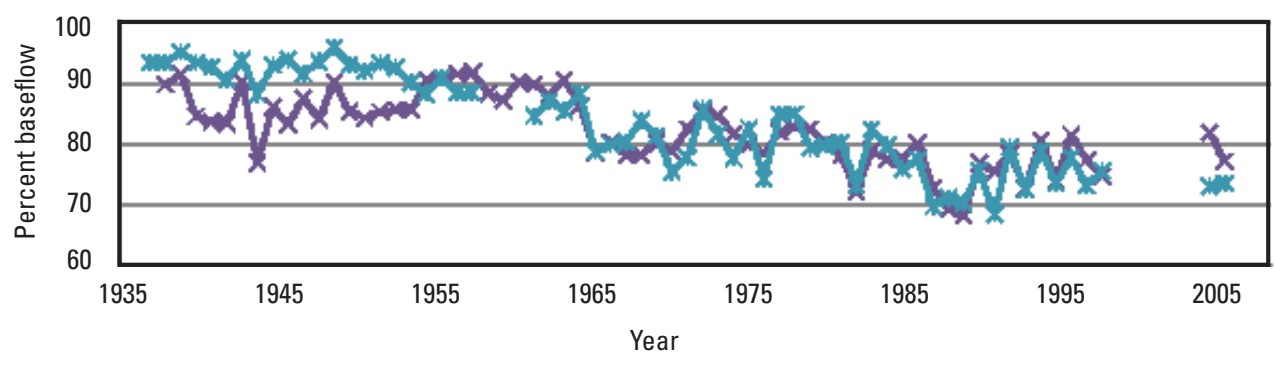

EXPLANATION

* Massapequa Creek

* Bellmore Creek

Figure 21. Baseflow (contribution of groundwater to streamflow) as a percentage of total flow, Massapequa and Bellmore Creeks, New York. (Locations shown in figure 5; from Rozell, 2010)

Table 6. Initial and final calibrated parameter values of a MODFLOW present steady state conditions model, as estimated by UCODE_2005, for site GM-38, Bethpage, New York.

[UCODE_2005 is documented in Poeter and others (2005). Values are in feet per day. Kx, horizontal hydraulic conductivity; $\mathrm{Kz}$, vertical hydraulic conductivity]

\begin{tabular}{lcccc}
\hline \multicolumn{1}{c}{ Parameter and zone } & $\begin{array}{c}\text { Initial value } \\
\text { (ARCADIS, 2010) }\end{array}$ & Lower limit & Upper limit & Final value \\
\hline Upper glacial Kx & 300 & 100 & 300 & 233 \\
Unconfined Magothy Kx & 200 & 75 & 250 & 170 \\
Magothy fine Kx & & 0.01 & 75 & 15 \\
Basal Magothy Kx & 60 & 50 & 100 & 61 \\
Raritan confining Kx & 1.0 & 0.0001 & 10 & 0.001 \\
Lloyd aquifer Kx & 75 & 0.1 & 100 & 75 \\
Magothy coarse Kx & 25 & 0.1 & 75 & 46 \\
Magothy interbedded Kx & & 0.1 & 75 & 55 \\
Upper glacial Kz & 60 & 1 & 100 & 80 \\
Magothy fine Kz & & 0.0001 & 75 & 3 \\
Basal Magothy Kz & 6.0 & 0.01 & 75 & 0.1 \\
Raritan confining Kz & 0.0001 & 0.00001 & 10 & 0.00001 \\
Lloyd aquifer Kz & 5.0 & 1 & 75 & 15 \\
Magothy coarse Kz & 1.0 & 0.01 & 75 & 1.7 \\
Magothy interbedded Kz & & 0.000001 & 75 & 0.00002 \\
Unconfined Magothy Kz & 40 & 0.1 & 100 & 80 \\
Recharge background & 0.00588 & 0.004 & 0.006 & 0.0058 \\
Recharge basins factor & 0.001 & 0.00001 & 0.01 & 0.0018 \\
Recharge loss factor & -0.00 & -0.00001 & -0.001 & 60005 \\
Drain conductance & & .01 & 100 & \\
\hline & & & & 50 \\
\end{tabular}



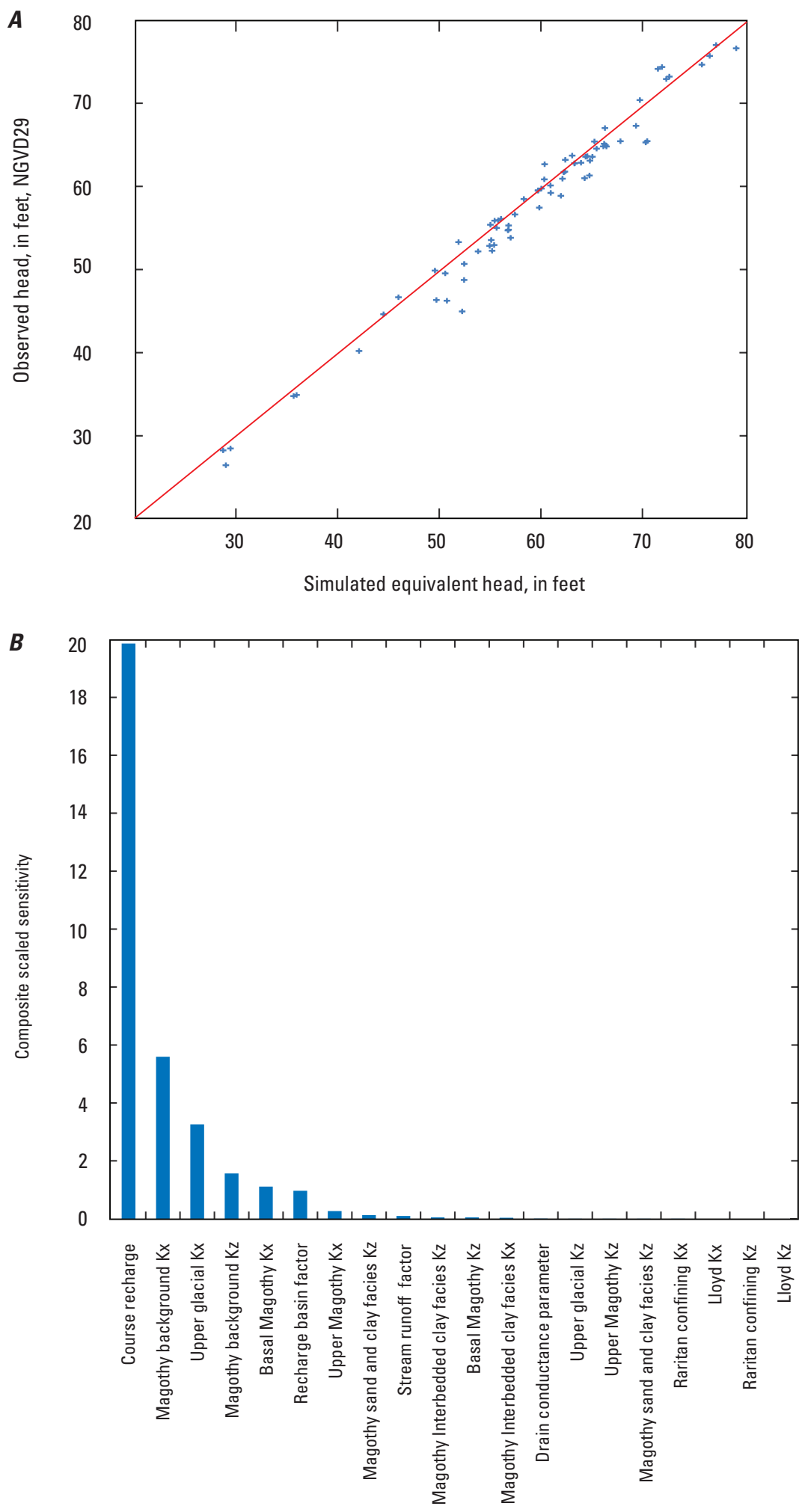

Figure 22. A, water level target residuals corresponding to present steady state model simulation Magothy aquifer heterogeneity realization $\mathrm{A}$, and $B$, composite scaled sensitivities corresponding to UCODE_2005 estimation of present steady state conditions MODFLOW parameters, Bethpage, New York. (Kx, horizontal hydraulic conductivity; Kz, vertical hydraulic conductivity) 
(b) lack of water-level data within the fine-grained beds. The confidence intervals of the fine-grained facies parameter estimates are relatively large, indicating that it is not possible to confidently estimate these parameters without more observational data. However, the UCODE_2005 was used to estimate these parameters (with optimized model fit) at values within allowed ranges. Estimated parameters included Magothy facies zones of only realization A; the global fit of the model was not strongly affected by the stochastic subdomain of heterogeneity realizations. Use of realization B or $\mathrm{C}$ resulted in changes to the objective function (least squares minimization of sum of squared residuals) that were smaller than the convergence criteria, indicating that UCODE_2005 would find a similar objective function minimum for each realization, thus precluding the need to recalibrate the model.

The results of the UCODE_2005 parameter estimation indicate that parameter values are similar but slightly different that those used in the ARCADIS (2010) model. The upper glacial aquifer horizontal and vertical hydraulic conductivities are estimated to be less than the ARCADIS (2010) model. The unconfined Magothy aquifer horizontal hydraulic conductivity is estimated to be greater than the ARCADIS (2010) model. The unconfined Magothy aquifer vertical hydraulic conductivity is estimated to be less than the ARCADIS (2010) model and is at the lower limit of the allowed range. The recharge rate is estimated to about 91 percent of the ARCADIS (2010) value, and the correlation coefficient between background recharge and upper layer unconfined hydraulic conductivity parameters is greater than 0.9 , indicating that the model results are nonunique with regard to estimating these parameters. (Decreasing recharge has a similar effect on the UCODE_2005 objective function as increasing hydraulic conductivity, rendering it impossible to discriminate between alternative models).

The Magothy aquifer coarse-grained facies and basal zone are estimated to have greater hydraulic conductivity than the ARCADIS (2010) model. The Magothy aquifer hydraulic conductivity estimations are not directly comparable to ARCADIS (2010) values due to the introduction in the USGS model of fine-grained beds within the Magothy aquifer. Similarly, the simulated recharge rate is about 91 percent of the ARCADIS (2010) value, but this value is not comparable due to additional recharge factors included in the present model. In terms of the overall model water budget, the simulated recharge rate is about 13 percent greater than that used in the ARCADIS (2010) model, with recharge added at recharge basins and subtracted where stormwater runs off to streams. Including additional recharge factors in the model calibration improved the objective function when compared to a single-parameter recharge parameter configuration and was not the cause of high correlation between background recharge and upper layer unconfined hydraulic conductivity parameters.

The final fit of the water levels simulated by the calibrated steady state model to observed water levels in the target wells may be assessed quantitatively with table 7 and figure 22. At the south end of the model, targets with the 6 lowest absolute water levels were higher than simulated. At the north end where absolute water levels are high, the highest observed water level is also higher than simulated, followed by a mix of positive and negative residuals that include many of the greatest absolute values. The mean weighted residual (simulated minus observed) $-1.16 \mathrm{ft}$, with 20 residuals greater than zero and 55 residuals less than zero. The sum of squared weighted water level residuals was 320.10 and the root mean square error was $2.07 \mathrm{ft}$.

Selected water level time series of the aquifer test were simulated by a transient state model using steady statecalibrated parameters, specific yield of 0.2 (model layer) and a specific storage of $1 \times 10^{-5} / \mathrm{ft}$ for all other layers, to demonstrate the match of simulate to observed water level changes in response to GM-38 pumpage, and to analyze sensitivity to Magothy heterogeneity realizations A, B, and C. At observation wells GM-38-RW1 MW1 (fig. 23) and GM-38-D1 (fig. 24), simulated water levels are a few feet below the measured water levels and at GM-38-D2 (fig. 25), the simulated water levels are a few feet above or below the measured water levels. The greater simulated/observed offsets of GM-38-RW1 MW1 (fig. 23) and GM-38-D1 may be due to resurveying of wells as part of the aquifer test (Tetratech, 2013). Simulated aquifer test response dynamics are clearly evident with respect to water level changes due to GM-38 pumpage rates at all observation well records and simulation results. Simulated aquifer test response dynamics are also slightly evident with respect to water level changes due to the uncontrolled public supply pumpage rate variations occurring randomly during the aquifer test. Variations of dynamic range are related to proximity to pumping stresses, and location with the hydrogeologic framework. Two sensitivity tests were conducted: (a) fine-grained facies hydraulic conductivity parameters were reduced from about $15 \mathrm{ft} / \mathrm{d}$ (horizontal) and $3 \mathrm{ft} / \mathrm{d}$ (vertical) to $1 \mathrm{ft} / \mathrm{d}$ (horizontal) and $0.001 \mathrm{ft} / \mathrm{d}$ (vertical), and (b) parameters were equalized to background Magothy values to represent the Magothy aquifer as homogeneous (results for well GM-38-D2 given in fig. 26). The results demonstrate that model sensitivity to the values of horizontal and vertical hydraulic conductivity of the fine-grained facies of the Magothy aquifer realization is low in terms of matching water levels in observation wells, likely due to the discontinuous nature of Magothy fine-grained beds in the vicinity of GM-38.

A greater sensitivity to heterogeneity realization may be expected for simulated particle pathway shapes than for water-level response, because particles take significantly more time to travel around fine-grained bed obstacles than the very short time required for water pressure equalization. Evaluating the sensitivity of the computed model responses to changes in parameter values that reflect plausible parameter uncertainty helps to assess the model reliability. 
Table 7. Simulated minus observed residuals of calibrated present steady state conditions model realization A for site GM-38, Bethpage, New York.

[Locations of observation wells and well clusters are shown in figure 19; well clusters are identified in figure 19 without final versioning suffix. Values corresponding to wells are in feet and gages in cubic feet per day]

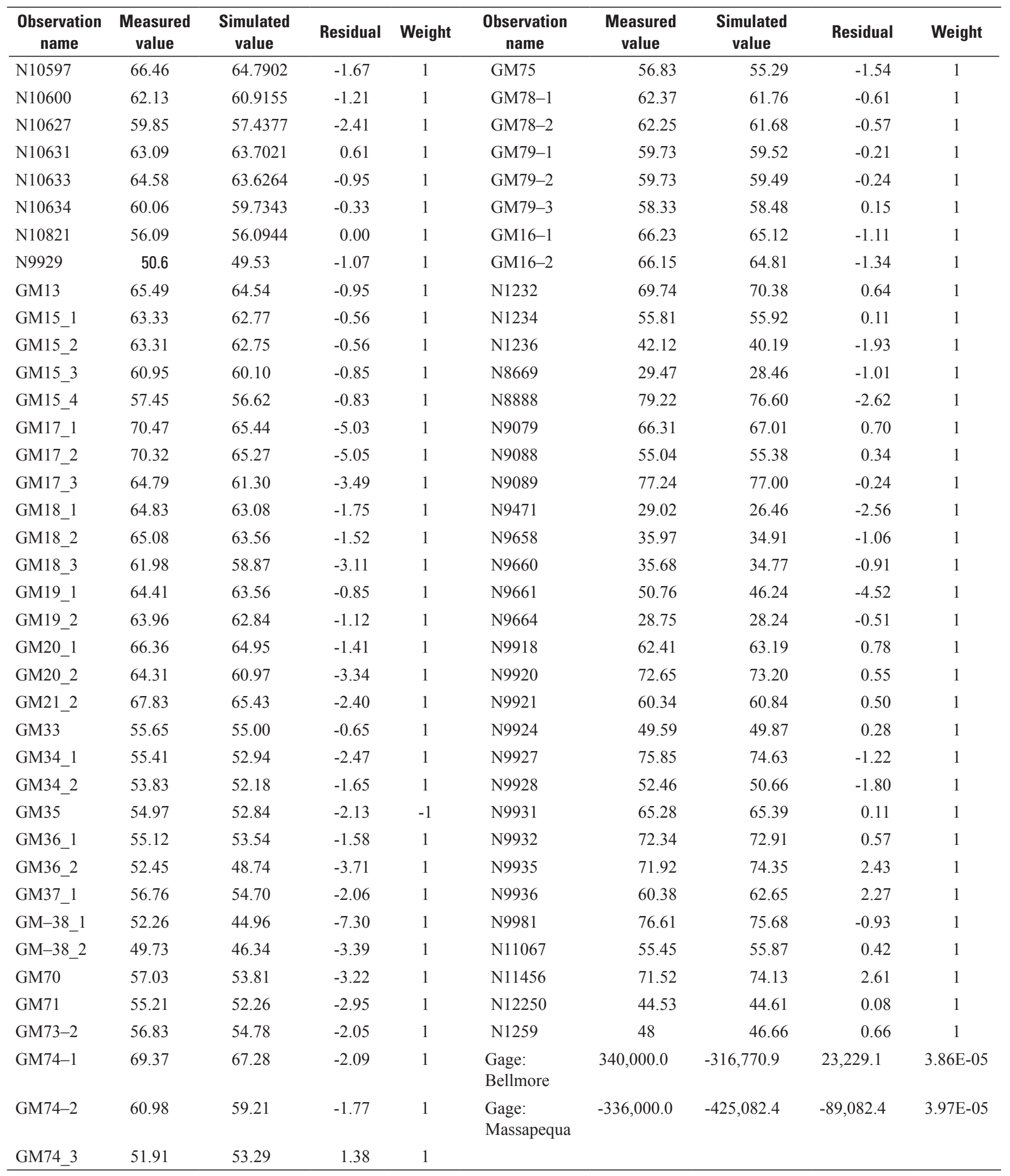


$\boldsymbol{A}$

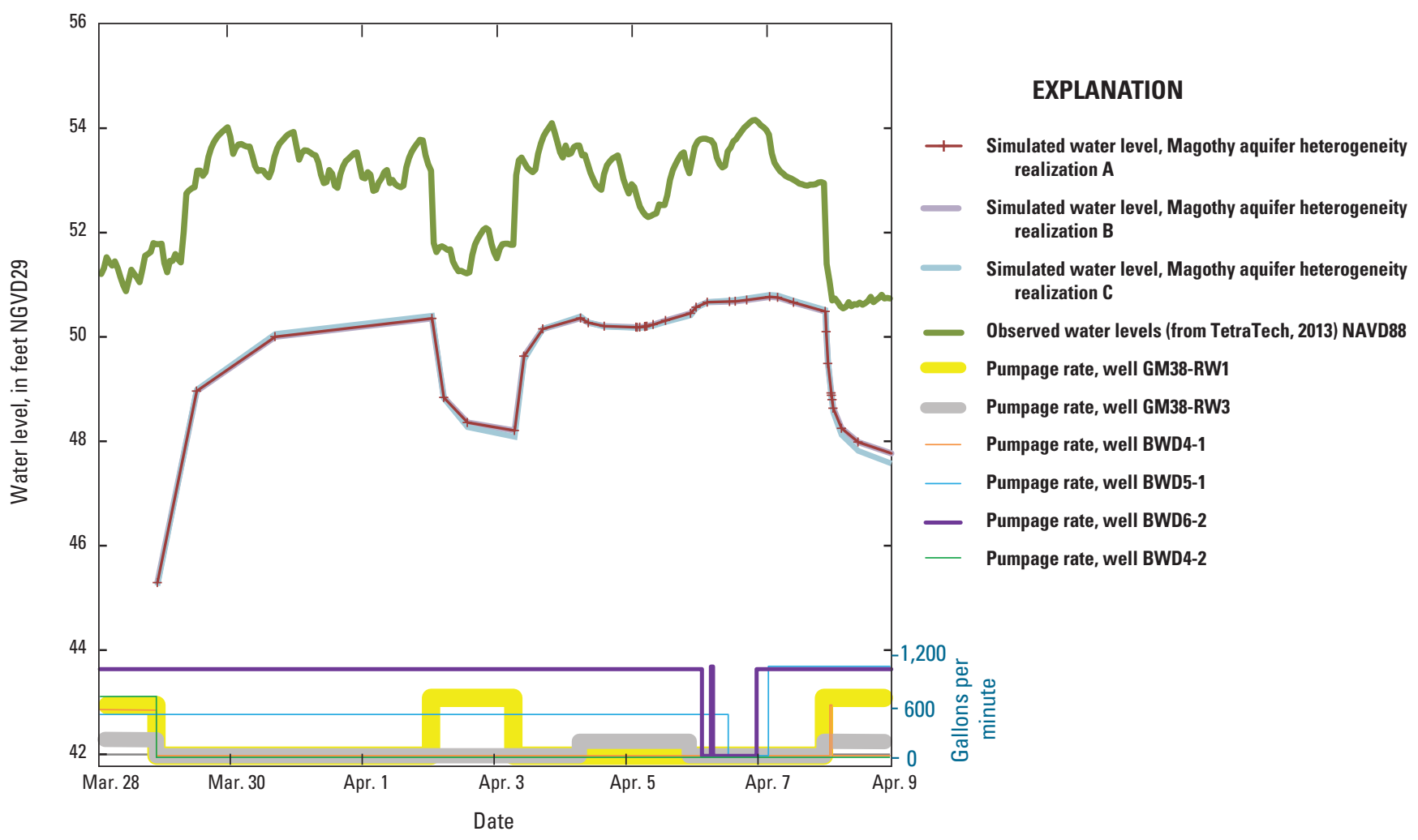

B

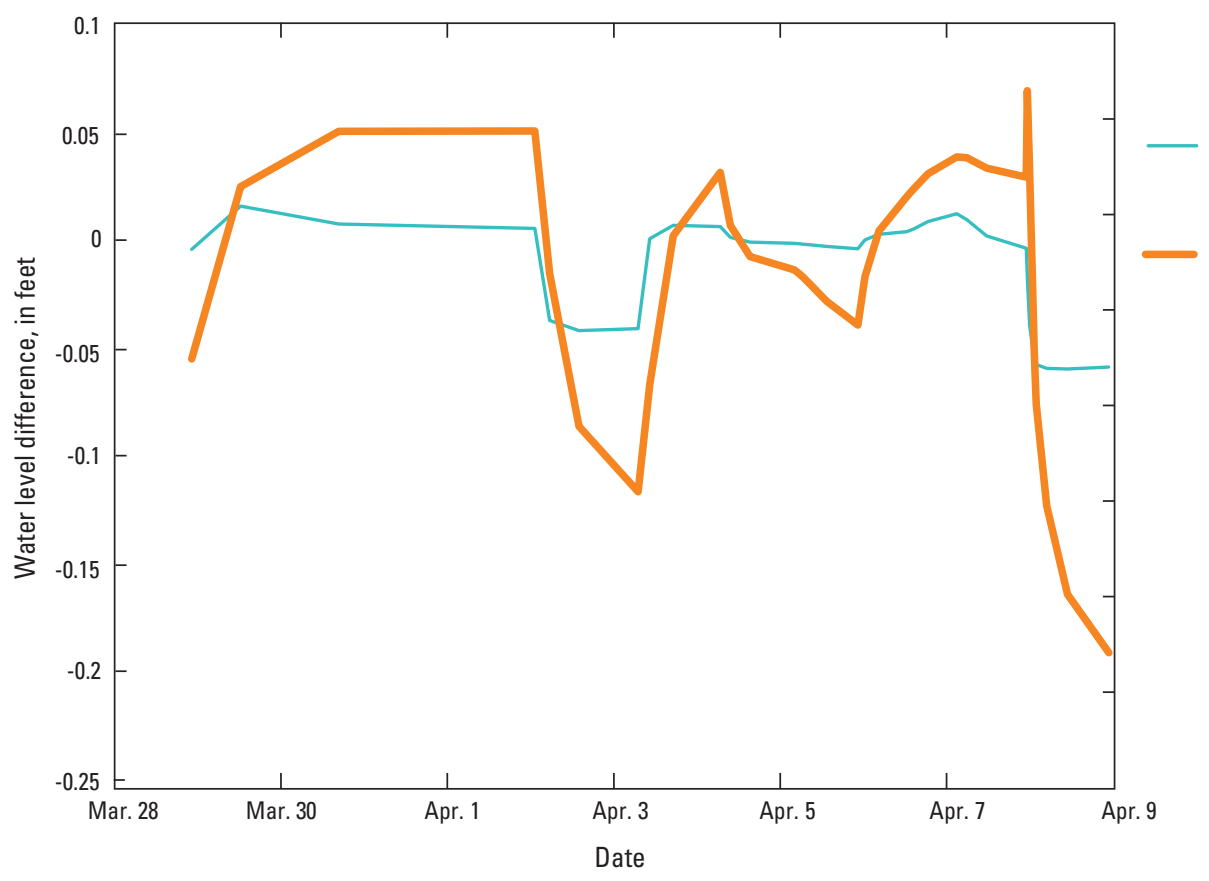

\section{EXPLANATION}

Difference in simulated water level,

Magothy aquifer heterogeneity realization B minus Magothy aquifer heterogeneity realization $\mathrm{A}$

Difference in simulated water level,

Magothy aquifer heterogeneity realization $C$ minus

Magothy aquifer heterogeneity realization $\mathrm{A}$

Figure 23. A, simulated transient-state water-level response of GM-38-RW1 MW1 associated with Magothy aquifer realizations $A, B$, and $C$, and history of pumpage rates, March to April 2013, and B, response differences between realization $A$ and $B$ and realization A and C, Bethpage, New York. (GM-38-RW1 MW1 location shown on figure 19) 


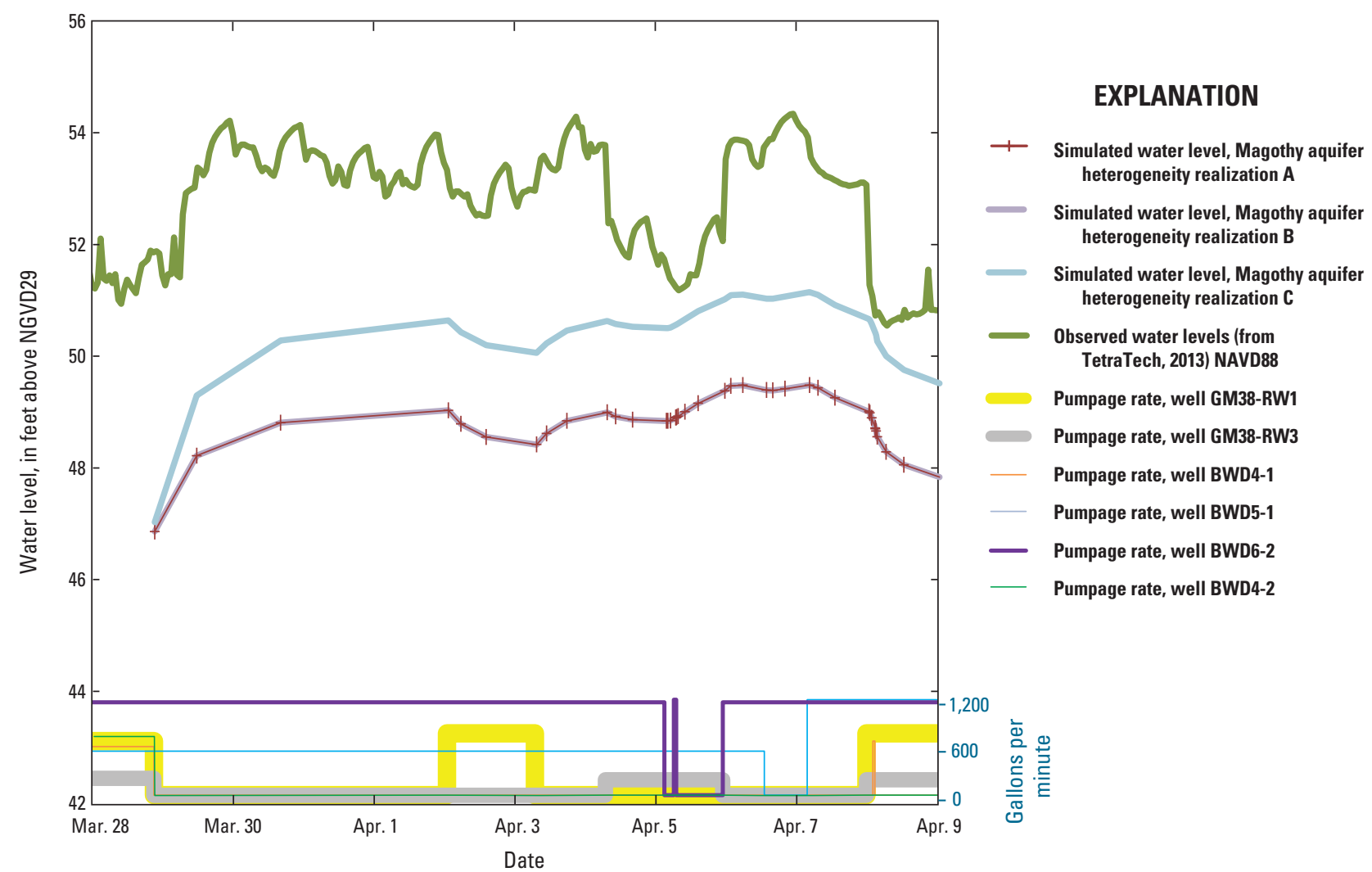

Figure 24. Simulated transient-state water-level response of GM-38-D1 associated with Magothy aquifer realizations A, B, and C, and history of pumpage rates, March to April 2013, Bethpage, New York. (GM-38-D1 location shown on figure 19 and well locations shown on figure 13) 


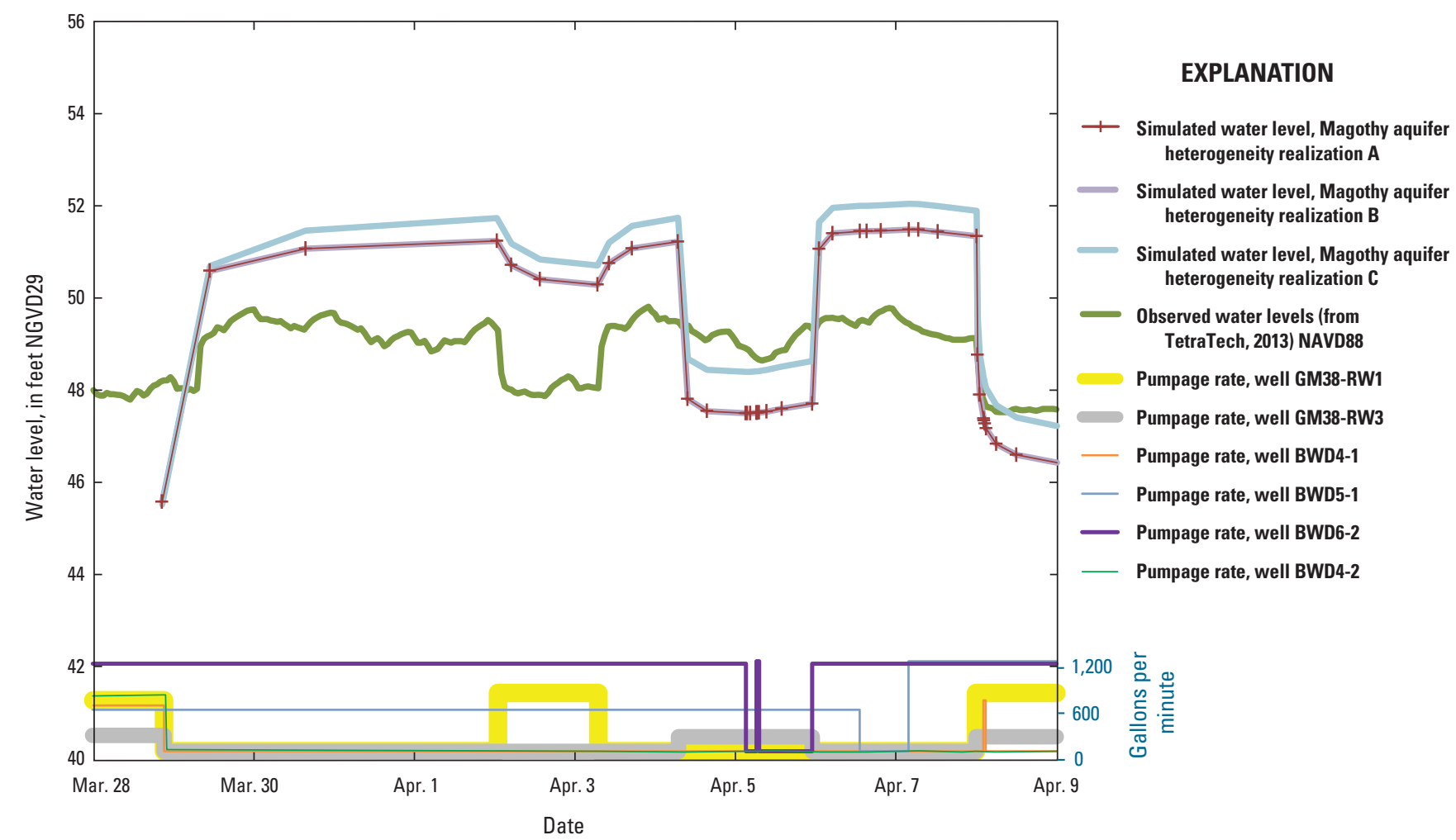

Figure 25. Simulated transient-state water-level response of GM-38-D2 associated with Magothy aquifer realizations A, B, and C, and history of pumpage rates, March to April 2013, Bethpage, New York. (GM-38-D2 location shown on figure 19 and well locations shown on figure 13) 


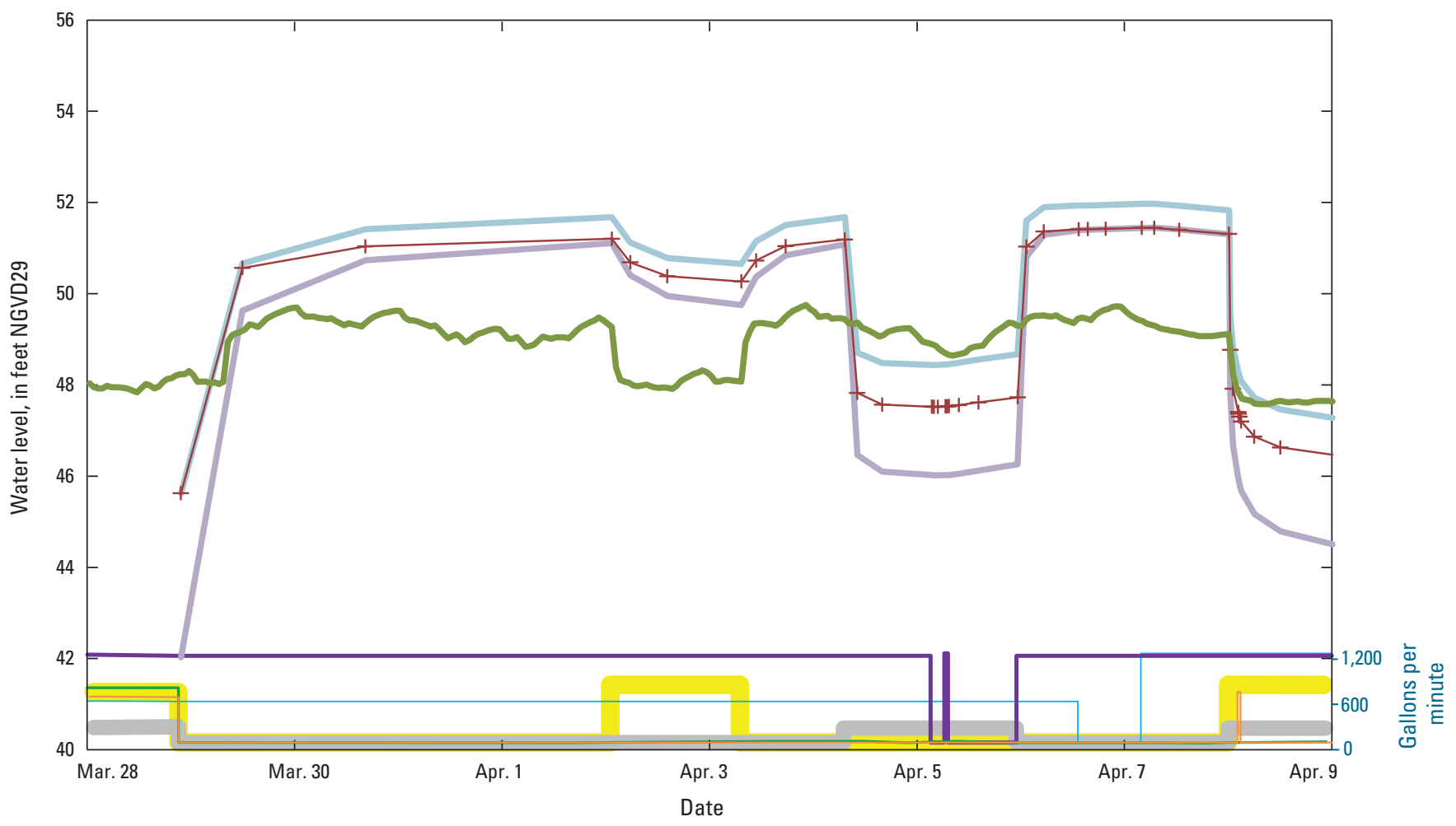

\section{EXPLANATION}
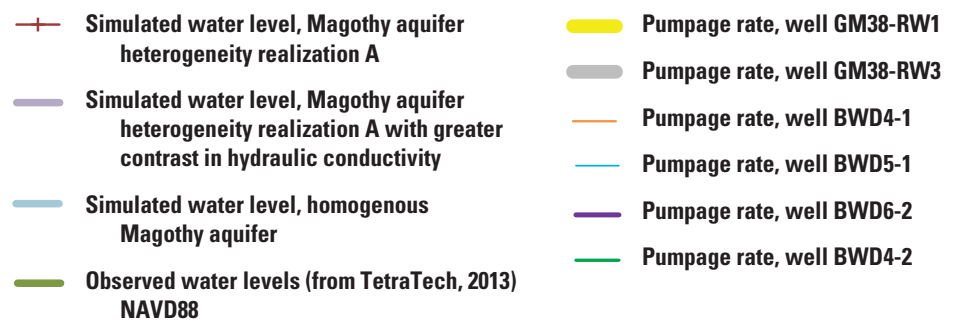

Figure 26. Transient state water-level response of GM-38-D2 associated with baseline simulation of Magothy aquifer heterogeneity realization $\mathrm{A}$, alternative simulation of homogeneous Magothy aquifer hydraulic conductivity, and alternative simulation of Magothy aquifer heterogeneity realization A with greater contrast of hydraulic conductivity, and history of pumpage rates, March to April 2013, Bethpage, New York. (GM-38-D2 location shown on figure 19) 


\section{Archived Model Information}

The steady state inputs and parameters of MODFLOW and MODPATH models include the following: arrays or matrices of cell-by-cell values, point sets, and scalar values. Arrays include top layer recharge, top and bottom model layer elevations, and most hydraulic conductivities. Point sets include constant-head boundary conditions, well discharges, recharge-basin flows receiving effluent from the OU2 onsite containment system ONCT, stream boundary conditions, and particle release points. Constant values are used for the following inputs, which are constant due to lack of spatial variability: bottom of model layer 1 (set to sea level), porosity, and conductivity of the Raritan confining unit.

\section{Zones of Contribution to Wells}

As discussed by Reilly and Pollock (1993), the term "source of water to wells" has been used in the hydrologic literature in two distinct contexts: a water-budget context and a transport context. The water-budget context addresses the water-budget components affected by water withdrawn from the groundwater system (for example, water withdrawn from a well can cause a net decrease in groundwater discharge to a stream). The transport context represents the plume geometry and the location where the water discharging from a well originally entered the groundwater system (see Franke and others, 1998). The transport context focuses on the flow paths of water to the actual point of discharge. The following transport terms below are considered standard terminology for USGS reports: (a) "area contributing recharge" and (b) "zone of contribution" (ZOC). The USGS does not use the term "capture zone" (as used by Tetra Tech, 2012b), which is a somewhat stronger term suggesting total capture including dispersion, as opposed to partial "contribution" (USGS, 2003) from MODFLOW-based advection.

"Area contributing recharge" is defined as the surface area on the boundary of the groundwater system that delineates the location of the water entering the groundwater system that eventually flows to the well (modified from Reilly and Pollock, 1993). This boundary is typically located on the water table; however, depending upon the definition of the groundwater system under investigation, it can be located along any boundary, such as a model zone where heterogeneity is represented explicitly using the transitional probability method, or a model zone corresponding to a plume delineation.

"ZOC" is defined as the three-dimensional volumetric part of an aquifer through which groundwater flows to a well from the area contributing recharge (modified from Morrissey, 1989). The ZOC can be visualized as a three-dimensional streamtube through the aquifer. Typically, these are projections to an areal view or a cross-sectional view. ZOCs are delineated through backwards tracking of particles that are initiated at wells, and simulated with present conditions steady state models. In this report, ZOC streamtubes are bounded by the pumping well and one or more of the following: (a) the water table recharge boundary, (b) specified flow boundaries representing recharge basins receiving waters from water treatment plants, and (c) various delineations of the surface boundaries or shells of the GM-38 Hot Spot plume solid, further described below.

Factors that affect the size and shape of 90-day, 1-year, and 2-year ZOCs to pumping wells GM-38-RW1 and GM-38-RW3 (fig. 27) are discussed in the following sections and include factors that affect the calibration of the present steady state conditions model and other factors such as porosity and retardation rate. The apparent overlap of ZOCs in plan view (fig. 27) is due to projection of maximum ZOC extent over the entire depth range, and may be addressed by (1) delineating ZOC slices along a sequence of depth intervals, or (2) by observing the points of pathline intersection at Hot Spot delineations.

Forward tracking of particles through the simulated groundwater-flow system may also be used to better understand how ZOC delineations relate to capture of waters originating in specific regions, such as plumes. The fate of contaminants that originate within the GM-38 Hot Spot solid may be analyzed by initiating particles within the solid and tracking forward through time. The lower boundary of the GM-38 Hot Spot plume solid may be assumed to be a flat plane at $350 \mathrm{ft}$ below sea level and the upper boundary a flat plane at $100 \mathrm{ft}$ below sea level, as presented in ARCADIS (2009). A folded box diagram (fig. 28) may be drawn that combines a plan view of particle starting locations within the GM-38 Hot Spot Plume solid with side views of (1) a north-south section along a model column, and (2) an eastwest section along a model row. The side views are pivoted at the edges of the plan view and rotated 90 degrees around a vertical (z) axis to lay flat and align with the plan view. Starting locations are projected onto the side view sections, which pass through the east side of the GM-38 recharge basin.

\section{GM-38 Zone of Contribution Analysis of Present Steady State Conditions Model Realization A}

Both forward and backward particle tracking was used to evaluate the ZOCs of GM-38 wells. Backward tracking was used to show how ZOCs relate to the TVOC concentration distribution and how effective are particular wells at intercepting high concentration parts of the plume. Forward tracking was used to evaluate how much of the GM-38 Hot Spot is being intercepted by the wells.

Analysis of the ZOCs of GM-38 wells was conducted by backtracking particles from well screens of the three GM-38 wells to points of intersection with the GM-38 Hot Spot. It is informative to differentiate inner and outer regions of the GM-38 Hot Spot, to accurately describe the locations of GM-38 wells relative to the TVOC concentration distribution 


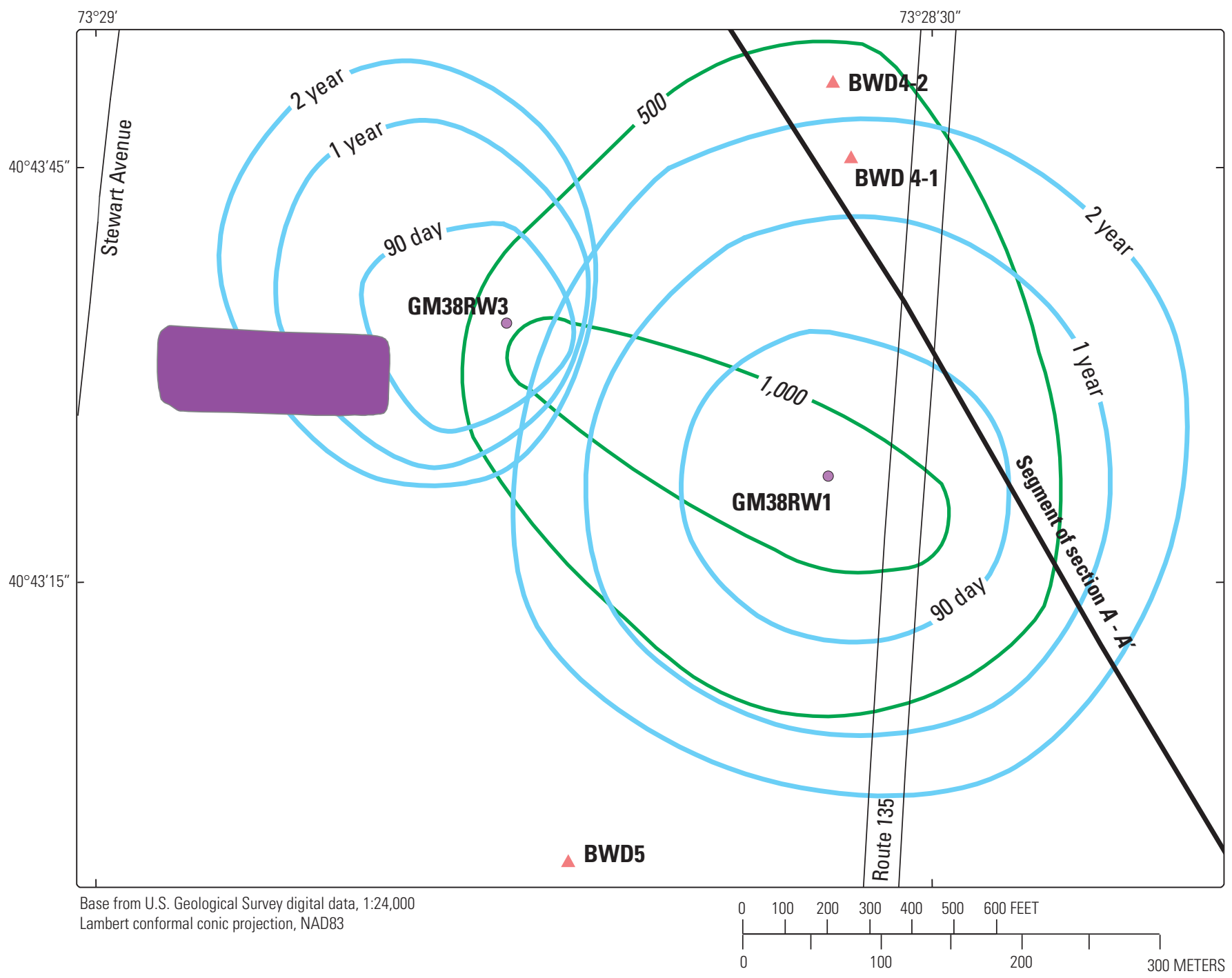

EXPLANATION

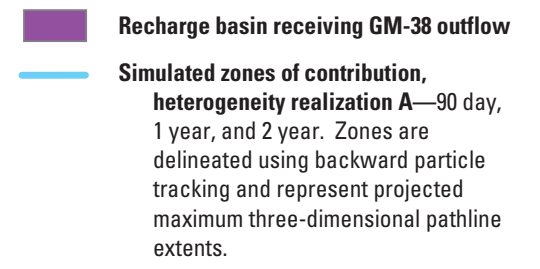
L Line of equal total volatile organic compound concentration, in parts per billion (ARCADIS, 2009)
$\triangle \quad$ BWD production wells
- GM-38 pumping wells

extents.

Figure 27. Zones of contribution represented as projections of maximum extent of three-dimensional particle pathlines tracked backward from pumping stresses at GM-38-RW1 and GM-38-RW3 after 90 days, 1 year, and 2 years, simulated using present steady state conditions model realization A, Bethpage, New York. 


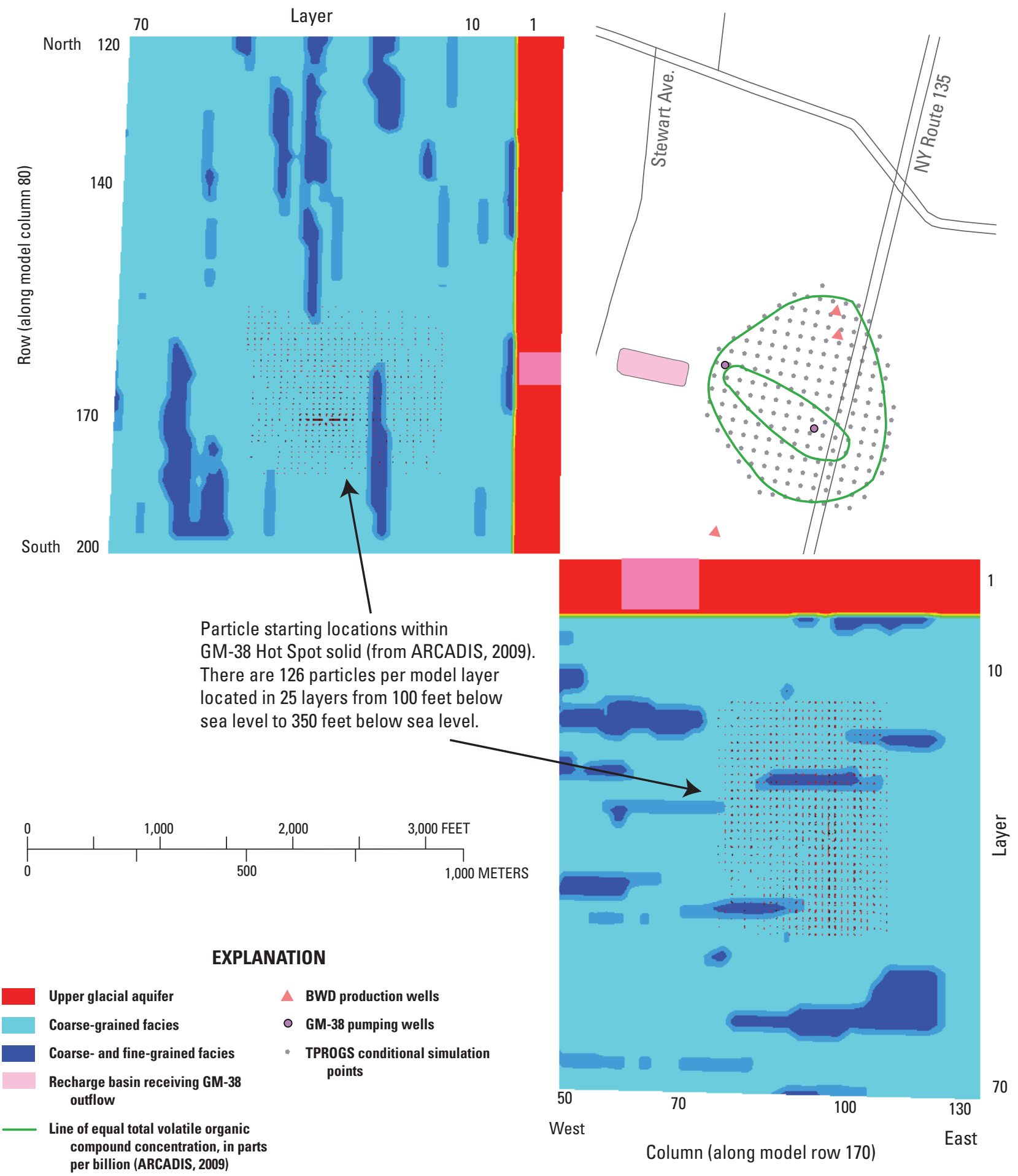

Figure 28. Plan view, rotated east-west section of model row 170, and rotated north-south section of column 80 , showing starting particle locations coincident with GM-38 Hot Spot solid (ARCADIS, 2009) and Magothy aquifer realization A, Bethpage, New York. 
given throughout the report (fig. 27), and to show how ZOCs relate to the TVOC concentration distribution. The inner solid of the GM-38 Hot Spot is defined by the interior volume of the 1,000 parts per billion (ppb) TVOC contour of ARCADIS (2009), from a lower flat plane of $350 \mathrm{ft}$ below sea level to an upper flat plane of $100 \mathrm{ft}$ below sea level. The outer solid ring is defined as the transition zone between the $500 \mathrm{ppb}$ TVOC contour of ARCADIS (2009) and the inner solid, with the same flat planes. The generic or total GM-38 Hot Spot solid (fig. 28) is the combined volume of the inner solid and the outer solid ring. Particles were distributed in each cell containing part of a well screen in a 5-by-5-by-5 pattern (125 particles per cell), and the particle backward-tracking analysis is summarized in table 8 .

MODPATH was used to simulate the position (fig. 29) of each particle along flow paths. Particles were backwardtracked with termination when one of the following conditions were met: (1) if the starting particle location is within a specified solid, then the tracking is terminated immediately at the start of the simulation, and (2) if the particle reaches a surface boundary of a specified solid, then the particle is terminated at the location of surface intersection, at an intermediate time during the simulation. If the particle does not meet a termination condition, then it is tracked to the point of water table recharge. Two backtracking analyses (fig. 29) are simulated using the baseline MODFLOW model: (1) points of intersection with the outer solid ring, and (2) points of intersection with the inner solid. GM-38-RW1 particle starting locations are completely contained within the inner solid and thus either travel backwards to terminate at the outer solid ring or immediately terminate within the inner solid. GM-38-RW3 particle starting locations at the well screen are completely contained within the outer solid ring. GM-38-RW3 particles either immediately terminate within the outer solid ring or travel backwards to terminate at the inner solid. Because the boundary of the inner solid is generally downgradient (to the southeast) of the GM-38-RW3 well screen, termination of particles at the inner solid is driven by the well's cone of depression (fig. 17).

All three GM-38 wells are associated with particle pathlines travelling underneath the Hot Spot solid, yet projected onto the map view. Particles not present within a solid are not terminated unless they intersect a solid, and therefore they may generate a pathline that is located underneath the solid. The well screen intervals of GM-38-RW1 and GM-38-RW3 are located completely within the GM-38 Hot Spot solids; however, depending on how the pathline termination condition is met, there may nevertheless be deep pathlines identified for these wells, typically representing a subset of pathlines influenced by well hydraulics (cones of depression). In such cases, the history of well capture may be considered to begin with waters of greater TVOC concentration and end with waters of lower TVOC concentration, sourced from below the Hot Spot. As pumping rate decreases, the hydraulic influence of cones of depression decreases and the well likely captures a greater percentage of high-TVOC water; however, the total mass of TVOC withdrawn decreases as the pumping rate decreases.

Sixty percent of the GM-38-RW2 well screen extends beyond the bottom plane of the GM-38 Hot Spot. All particles started at the GM-38-RW2 screen zone, including those started below the plane at $350 \mathrm{ft}$ below sea level, terminate at the outer solid ring (fig. 29). However, not all the particles travel through the inner solid. About 4 percent of particles that are started below the plane at $350 \mathrm{ft}$ below sea level ( 2 percent of all well particles) travel only through the outer solid ring and do not travel through the inner solid. This suggests that even at very low levels of pumping, GM-38-RW2 may yield some water, coming into the well from the bottom part of the well screen beneath the Hot Spot, which is of lower TVOC concentration and does not pass through the high-TVOC inner solid. As pumping rate increases, the percentage of lowerTVOC concentration water captured likely increases due to hydraulic influences.

Table 8. Comparison of backward-tracked particle starting points at GM-38 well screens with model layers and GM-38 Hot Spot solids, Bethpage, New York.

[ft, feet]

\begin{tabular}{lrrr}
\hline \multicolumn{1}{c}{ Well } & $\begin{array}{c}\text { GM-38- } \\
\text { RW1 }\end{array}$ & GM-38-RW2 & GM-38-RW3 \\
\hline Number of particle starting points & 500 & 750 & 375 \\
Model layer of well screen top & 29 & 40 & 1,625 \\
Model layer of well screen bottom & 32 & 45 & 31 \\
Model layer of solid top plane & & 13 \\
(100 ft below sea level) & & 13 \\
Model layer of solid bottom plane & & 41 \\
(350 ft below sea level) & 41 & 41 \\
Percentage of model layers representing well screen that are within solid & 100 & 40 \\
Hot Spot solid within which well screen is located & Inner & Inner & Outer ring \\
\hline
\end{tabular}




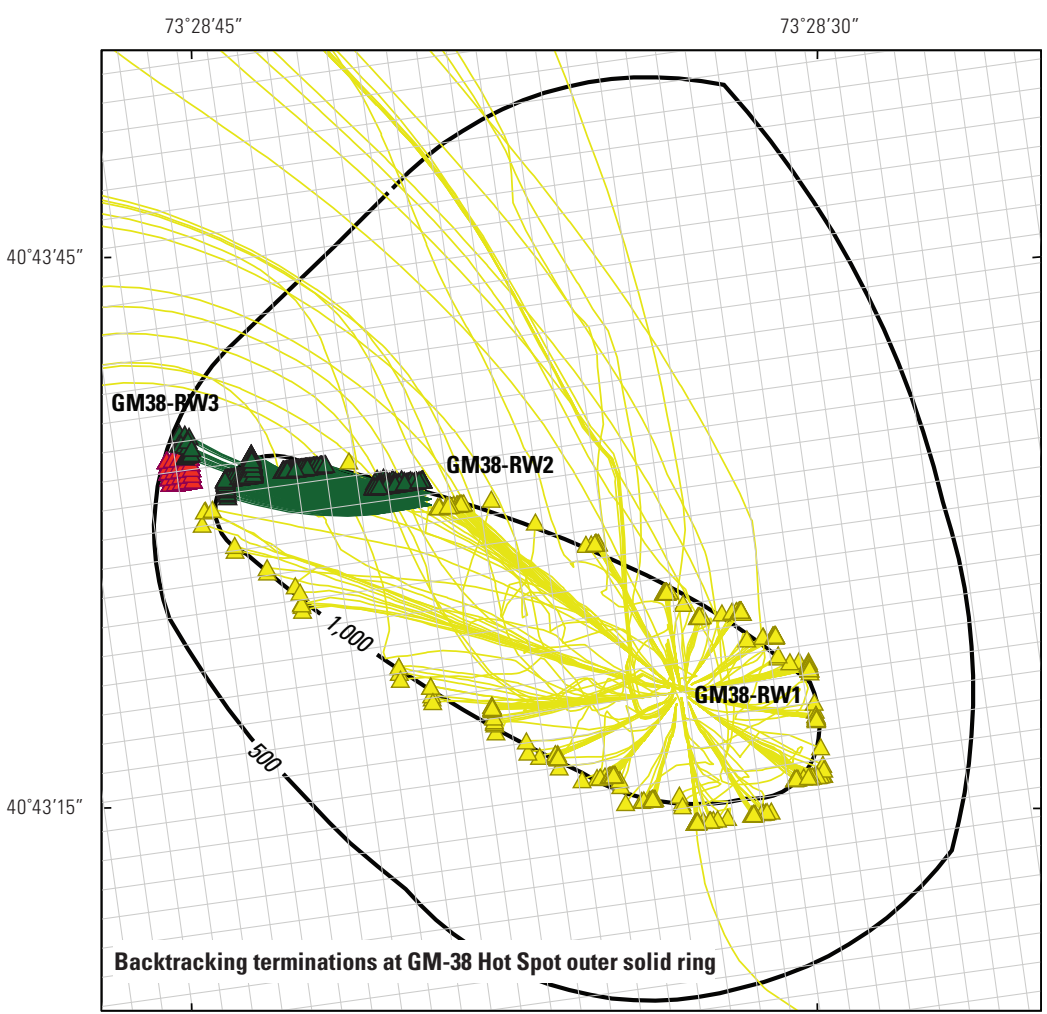

Base from U.S. Geological Survey digital data, 1:24,000

Lambert conformal conic projection, NAD83

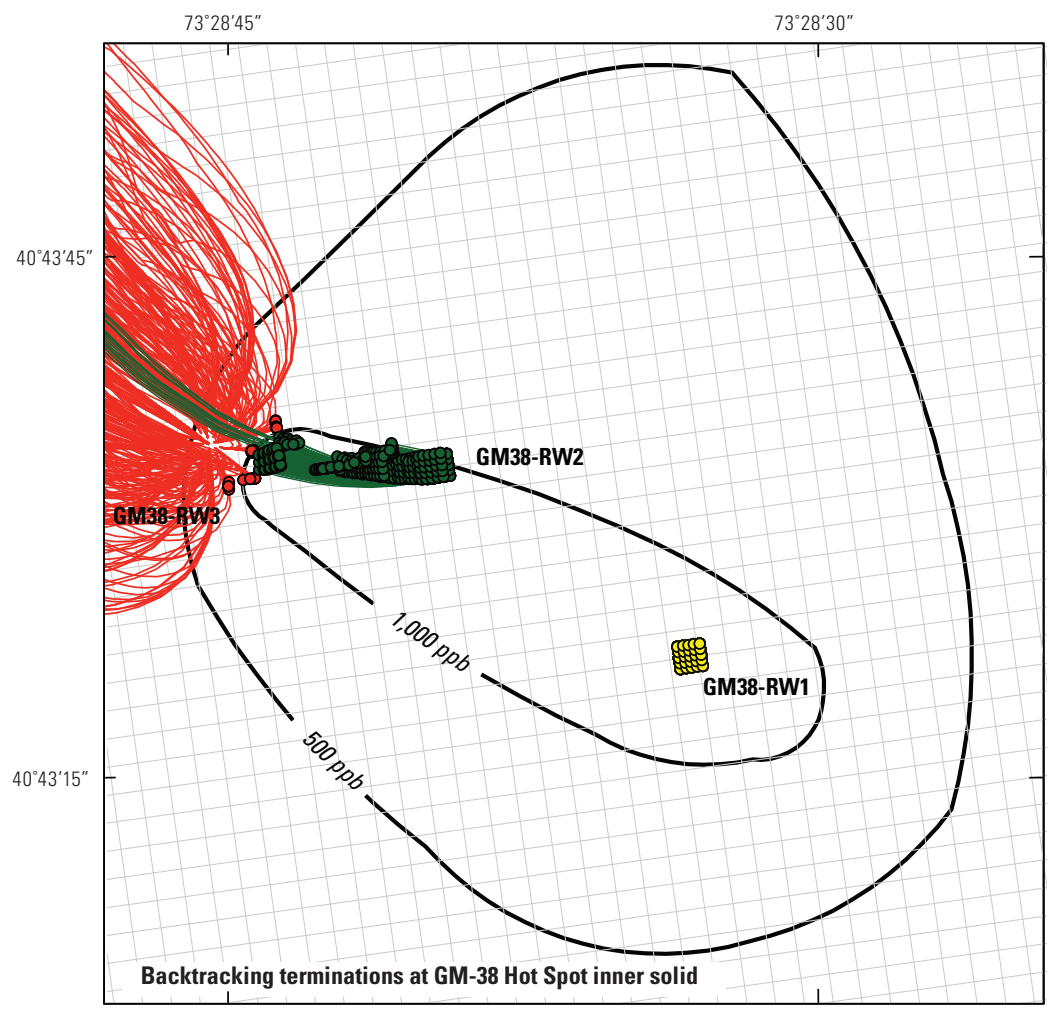

Base from U.S. Geological Survey digital data, 1:24,000

Lambert conformal conic projection, NAD83

\section{EXPLANATION}

TERMINATIONS AT GM-38 Hot Spot solid (from ARCADIS, 2009), Magothy aquifer heterogeneity realization $A$

$\Delta$ GM38-RW3 particles terminated at outer solid ring

$\Delta$ GM38-RW2 particles terminated at outer solid ring

$\triangle$ GM38-RW1 particles terminated at outer solid ring

- GM38-RW3 particles terminated at inner solid

- GM38-RW2 particles terminated at inner solid

- GM38-RW1 particles terminated at inner solid

- Line of equal total volatile organic compound concentration, in micrograms per liter (from ARCADIS, 2009)

Model grid

Backtracked pathlines associated with GM38-RW3

Backtracked pathlines associated with GM38-RW2

Backtracked pathlines associated with GM38-RW1

Figure 29. Projected pathlines captured by GM-38-RW wells and backward tracked using a present steady state conditions model and Magothy aquifer heterogeneity realization A, Bethpage, New York. 
Particle backtracking analysis of the ability of a well to capture water from within the GM-38 Hot Spot is summarized in table 9. In general, the ZOC of GM-38-RW1 captures significantly more TVOC mass than GM-38-RW3. This is mainly due to the more central location within the GM-38 Hot Spot of GM-38-RW1 than GM-38-RW3, but also due to the greater pumping rate. GM-38-RW1 is located within the inner solid, whereas GM-38-RW3 is located within the outer solid ring. GM-38-RW2 does not capture TVOC mass because it is not pumping in the present steady state conditions simulation.

The fate of contaminants residing within the GM-38 Hot Spot solids, and how much TVOC mass is being intercepted by wells, may be demonstrated by analysis of forward-tracked particles. Similar to the preceding backtracking analysis, it is informative to start forward-tracked particles within the inner and outer solids of the GM-38 Hot Spot to show how ZOCs relate to the TVOC concentration distribution. With starting points distributed throughout the GM-38 Hot Spot, statistics of final destinations at wells and other model discharge boundaries may be generated. Table 10 gives the percentage of particles captured by model discharge boundaries.

Corresponding to the results of the backtracking analysis, the vast majority of the Hot Spot is captured by GM-38-RW1, with minor captures by GM-38-RW3, and BWD4. The plume is not captured by GM-38-RW2 as this well is not pumping in the simulated present steady state condition.

\section{Variability Based on Modifications to the Model}

Comparison of particle tracking generated from hypothetical alternate models (figures 30-34) demonstrates additional influences on the characteristics of ZOCs to GM-38 wells and may be considered a sensitivity analysis. Variations include alternate porosity, alternate Magothy aquifer heterogeneity realizations $\mathrm{B}$ and $\mathrm{C}$, alternate delineation of Hot Spot solid geometry, and alternate pumping rates.

\section{Porosity}

Porosity parameters directly correlate to MODPATH particle travel time, and there is significant uncertainty in choosing a value. The baseline porosity parameter value is 0.25 , is used in the ARCADIS model (2010), and is in the middle of a range between 0.15 and 0.35 (Misut and Aphale, 2014). An alternate model with porosity of 0.15 would result in shorter particle travel times (table 11). Backward-tracked travel times are greater than forward-tracked travel times, because backward tracking averages include some long pathlines extending to the water table far upgradient of the Hot Spot. Varying porosity does not affect the MODFLOWgenerated flow field; furthermore, this parameter may not be calibrated using water-level data. To calibrate porosity parameters, a transient state model with solute concentration observations is typically necessary. In addition, porosity likely varies spatially.
Table 9. Summary of particle backtracking analysis of GM-38 wells, present steady state conditions, Bethpage, New York.

[gal/min, gallons per minute]

\begin{tabular}{|c|c|}
\hline \multicolumn{2}{|l|}{ Pumping rates } \\
\hline GM-38-RW1 pumping & $700 \mathrm{gal} / \mathrm{min}$ \\
\hline GM-38-RW2 pumping & $0 \mathrm{gal} / \mathrm{min}$ \\
\hline GM-38-RW3 pumping & $220 \mathrm{gal} / \mathrm{min}$ \\
\hline \multicolumn{2}{|l|}{ Particle characteristics } \\
\hline Total particles backtracked & 1,625 \\
\hline Inner solid terminations & 1,170 \\
\hline Percentage of inner solid termination & 72.0 \\
\hline $\begin{array}{l}\text { Average travel time of pathlines with inner } \\
\text { solid termination }\end{array}$ & 1,359 days \\
\hline Outer solid ring terminations & 1,596 \\
\hline Percent outer solid ring termination & 98.2 \\
\hline $\begin{array}{l}\text { Average travel time of pathlines with outer } \\
\text { solid ring termination }\end{array}$ & 1,596 days \\
\hline $\begin{array}{l}\text { GM-38-RW1 terminations at outer solid } \\
\text { ring }\end{array}$ & 346 \\
\hline $\begin{array}{l}\text { GM-38-RW1 percent capture outer solid } \\
\text { ring } \\
\quad \text { (GM-38-RW1 screen is located within } \\
\quad \text { inner solid })\end{array}$ & 92.3 \\
\hline GM-38-RW2 terminations at inner solid & 736 \\
\hline $\begin{array}{l}\text { GM-38-RW2 terminations at outer solid } \\
\text { ring } \\
\text { (GM-38-RW2 screen is } 40 \text { percent } \\
\quad \text { within inner solid) }\end{array}$ & 750 \\
\hline GM-38-RW3 terminations at inner solid & 59 \\
\hline $\begin{array}{l}\text { GM-38-RW3 percent capture inner solid } \\
\text { (GM-38-RW3 screen is located within outer } \\
\text { solid ring) }\end{array}$ & 15.7 \\
\hline
\end{tabular}

Table 10. Percentage of capture of forward tracked particles started within the GM-38 Hot Spot inner solid and outer solid rings (ARCADIS, 2009) simulated by a present steady state model and Magothy aquifer heterogeneity realization A, Bethpage, New York.

\begin{tabular}{lcc}
\hline \multicolumn{1}{c}{ Well } & $\begin{array}{c}\text { Percentage of } \\
\text { particles started } \\
\text { within outer } \\
\text { solid ring }\end{array}$ & $\begin{array}{c}\text { Percentage of } \\
\text { particles started } \\
\text { within inner solid }\end{array}$ \\
\hline GM-38-RW1 & 75.1 & 89.1 \\
GM-38-RW2 & 0 & 0 \\
GM-38-RW3 & 6 & 5.5 \\
Sum of & 81.1 & 94.6 \\
GM-38-RW wells & & 0 \\
BWD 4-1 & 0.3 & 5.4 \\
BWD 4-2 & 18.6 & \\
\hline
\end{tabular}


Table 11. Comparison of average travel time of particles in days, baseline and alternate porosity, simulated by a present steady state model for site GM-38, Bethpage, New York.

[ppb, parts per billion]

\begin{tabular}{lcc}
\hline \multicolumn{1}{c}{ Porosity } & $\begin{array}{c}\text { Baseline } \\
\mathbf{0 . 2 5}\end{array}$ & $\begin{array}{c}\text { Alternate } \\
\mathbf{0 . 1 5}\end{array}$ \\
\hline \multicolumn{2}{c}{ Average travel time (days) } \\
\hline Forward from 1,000 ppb shell & 294 & 176 \\
Forward from 500 ppb shell & 462 & 277 \\
Backward to 1,000 ppb shell & 1,359 & 815 \\
Backward to 500 ppb shell & 1,596 & 958 \\
\hline
\end{tabular}

\section{Heterogeneity}

Because the GM-38 Hot Spot is located within the Magothy aquifer and heterogeneity within this formation has the potential to affect ZOCs, a preliminary analysis of three alternative conditional simulations of Magothy aquifer heterogeneity were generated. These simulations demonstrate the influence of fine-grained facies on plume transport, however, they do not represent a statistically significant sampling. These heterogeneity realizations are equally probable and potentially result in different simulated water particle pathways and corresponding ZOCs. However, because all realizations honor the available boring and well data, there is a limit to the variability between realizations. Realizations A and B (fig. 12), do not result in significant variability of ZOCs, while realization $\mathrm{C}$ differs from realizations $\mathrm{A}$ and $\mathrm{B}$ and results in some variability of ZOCs. Comparison of realizations $\mathrm{A}, \mathrm{B}$, and $\mathrm{C}$ near the GM-38 pumping wells (near the right corner to the southeast in figure 12), shows there are fewer model cells representing the finer-grained facies and the horizontal to vertical anisotropy is less. At the southwest corner of the heterogeneity realization blocks (foreground of figure 12), the dominant fine-grained bed in the upper part of the block is noticeably thinner in realization $\mathrm{C}$, but an interbedded fine-grained bed in the lower part of the block is also extended in realization $\mathrm{C}$.

In realizations $\mathrm{A}$ and $\mathrm{B}$, forward tracking from the total Hot Spot solid (500 ppb TVOC contour) results in capture of all particles by wells (fig. 30). In realization C, particles start to flow away from wells and the plume solid. A few particles stagnate beyond the Hot Spot and briefly leave the heterogeneity realization, then switch direction in the regional grid to be eventually pulled back into wells (fig. 30). This is likely due to channeling of particles into the higher hydraulicconductivity Magothy coarse-grained facies and out of the fine-grained facies, allowing particles to travel farther than they otherwise might travel in a homogenous aquifer matrix. About 0.2 percent of particles continue flowing southward beyond the heterogeneity subgrid and ultimately to model constant head boundaries.
Forward tracking from the inner Hot Spot solid (fig. 31, $1,000 \mathrm{ppb}$ TVOC contour) results in shorter travel times and more direct capture of all particles than for forward tracking from the total Hot Spot solid (500 ppb TVOC contour), due to the compact and centrally located shape of the inner solid. Use of alternate realization $\mathrm{C}$ results in greater dispersal of stagnation points; however, unlike the forward tracking from total Hot Spot solid, particles of the inner solid do not continue to points of discharge at the southern model constant head boundaries.

\section{Hot Spot Delineation}

The shape of the GM-38 Hot Spot solids likely changes, as a response to stresses, and its delineation depends on available data and methods of interpretation. Forward tracking analysis was conducted starting from alternate solid delineations (figs. 32, 33), based on 500 and $1,000 \mu \mathrm{g} / \mathrm{L}$ TVOC distribution of Tetra Tech (2002). Tetra Tech (2002) defines a larger Hot Spot area than ARCADIS (2009), likely due to an earlier time of delineation and incorporation of data not used by ARCADIS (D. Brayack, TetraTech, written communication, 2013). The Tetra Tech 500 ppb TVOC contour extends southwest to the site of BWD 5-1, whereas the ARCADIS contour does not. For all heterogeneity realizations, particles starting from the alternate total Hot Spot solid (1,000 ppb TVOC contour of Tetra Tech, 2002) result in some stagnation beyond the heterogeneity realization subgrid and some particles continuing to points of discharge at the southern model constant head boundaries (fig. 32). The boundary of the heterogeneity subgrid has a greater hydraulic effect for realization $\mathrm{C}$ than for realizations $\mathrm{A}$ and $\mathrm{B}$. The numbers of particles captured by constant head boundaries are as follows: realization A: 20 out of 34,474 ; realization B: 16 out of 34,474; and realization C: 85 out of 34,474 .

In realizations $\mathrm{A}$ and $\mathrm{B}$, forward tracking from the alternate Hot Spot inner solid as delineated by the 1,000 ppb TVOC contour of Tetra Tech (2002) results in capture of all particles by wells. Use of realization C results in slightly greater stagnation beyond the solid (fig. 33).

\section{Pumping Rates}

Pumping stresses influence characteristics of ZOCs to GM-38 wells. As pumping stress increases, the cone of depression generally deepens and spreads out. This can reshape backward-tracked particle pathlines such that greater or fewer particles intersect Hot Spot solids and reshape forward-tracked particle pathlines to change the percentage of particles captured by points of model discharge. Three hypothetical scenarios are generated with varying pumping rates of BWD4 and GM-38 wells. Together with these scenarios, Magothy aquifer realizations $\mathrm{A}$ and $\mathrm{C}$ are also considered. Hypothetical results corresponding to model realization B are similar to results of model realization A. 


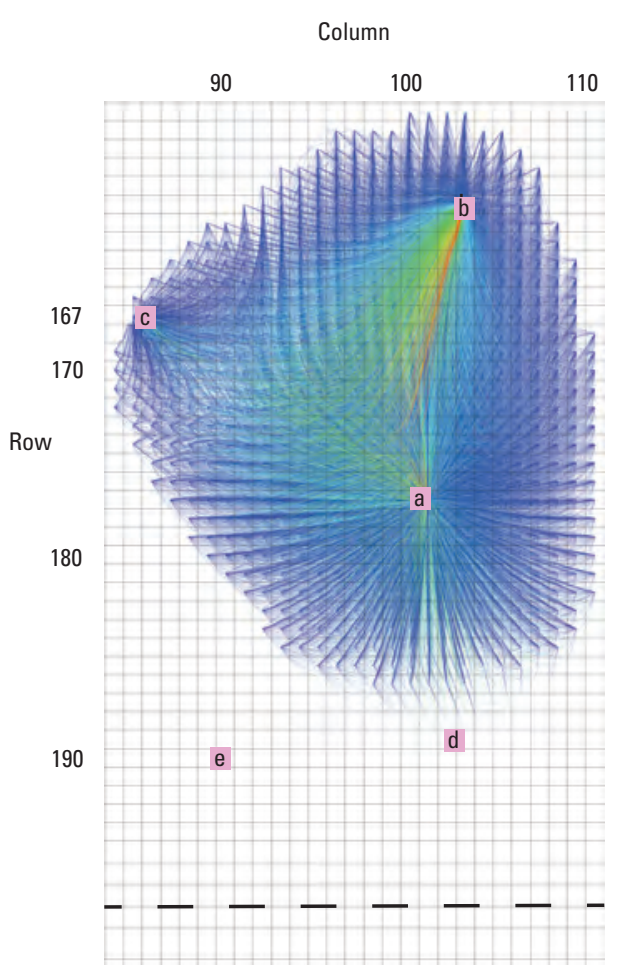

Realization A:

Average travel time: 462 days

$59 \%$ have travel time < average

500 parts per billion plume shell (-100 to-350 ft above sea level, ARCADIS, 2009):

BWD $4-1$ captures $0.3 \%$

BWD $4-2$ captures $18.6 \%$

GM 38-RW3 captures $6.0 \%$

GM 38-RW1 captures $75.1 \%$
Column

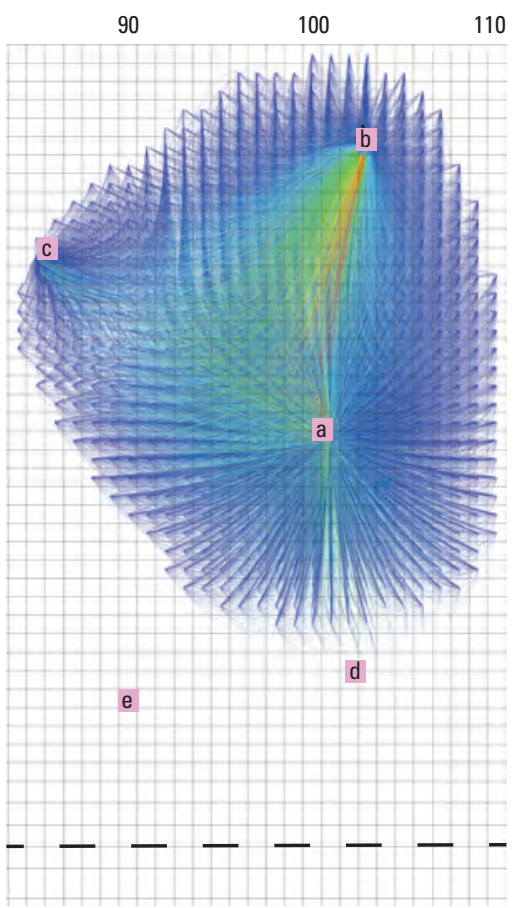

$\begin{array}{lll}0 & 500 & 1,000 \text { FEET } \\ \stackrel{1}{1} & 1 & 1 \\ 0 & 150 & 300 \text { METERS }\end{array}$

Realization B:

Average travel time: 464 days

$59 \%$ have travel time < average

500 parts per billion plume shell (-100

to-350 ft above sea level,

ARCADIS, 2009):

BWD 4-1 captures $0.3 \%$

BWD 4-2 captures $18.4 \%$

GM 38 -RW3 captures $5.9 \%$

GM 38-RW1 captures $75.4 \%$

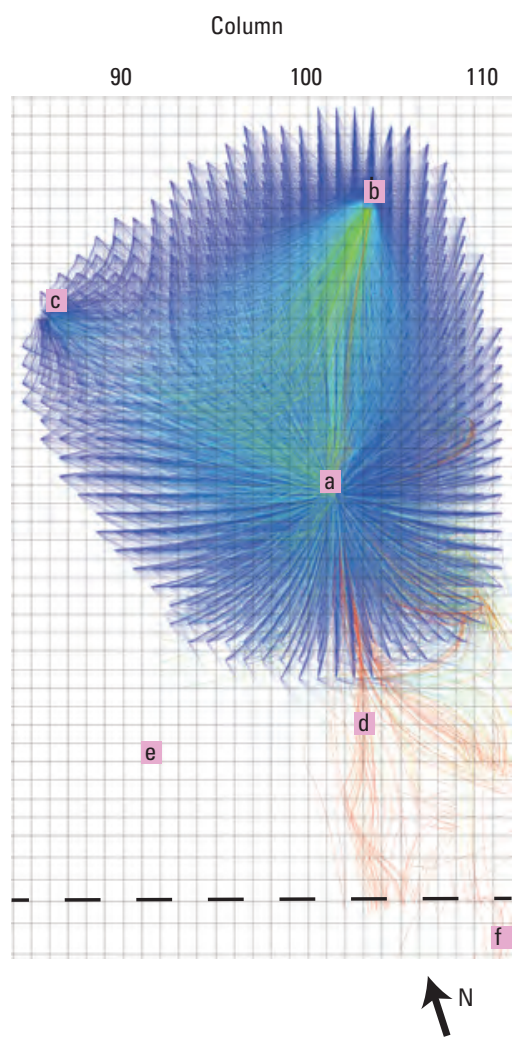

Realization C:

Average travel time: 637 days

$70 \%$ have travel time < average

500 parts per billion plume shell (-100

to-350 $\mathrm{ft}$ above sea level,

ARCADIS, 2009):

BWD 4-1 captures $0.2 \%$

BWD 4-2 captures $14.2 \%$

GM 38-RW3 captures $5.5 \%$

GM 38-RW1 captures $79.9 \%$

Constant head captures $0.2 \%$

\section{EXPLANATION}

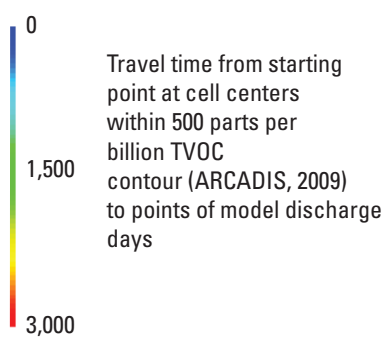

a GM38-RW1 pumping well

b BWD-4 pumping wells

C GM38-RW3 pumping well

d Stagnation points beyond the $\mathbf{5 0 0}$ parts per billion TVOC contour (ARCADIS, 2009)

e BWD-5 pumping well

f Pathlines that continue to constant head boundaries

- - Southern boundary of heterogeneity realization subgrid

Figure 30. Travel time and pathlines of forward-tracked particles started at the total GM-38 Hot Spot solid during present steady state conditions and Magothy aquifer heterogeneity realizations $A, B$, and C, model grid, southern extent of heterogeneity realization subgrid, and locations of particle discharge, Bethpage, New York. 


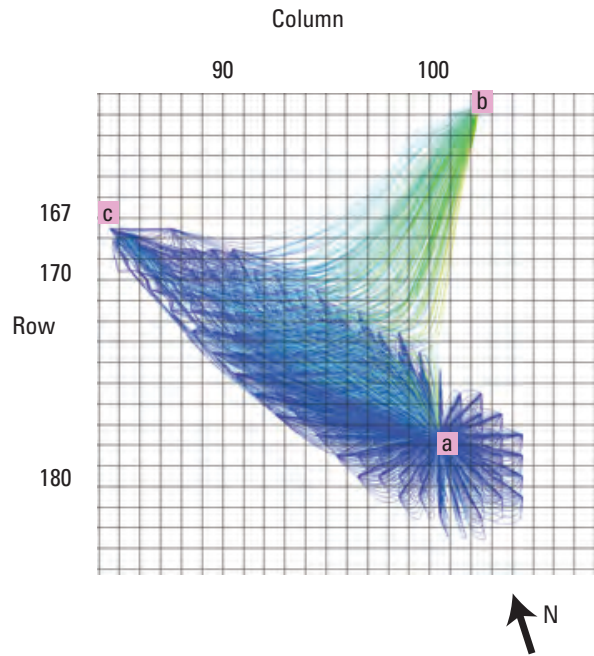

Realization A:

Average travel time: 294 days

$63 \%$ have travel time < average

\begin{abstract}
$1,000 \mathrm{ppb}$ plume shell $(-100$ to-350 ft above sea level, ARCADIS, 2009):

BWD 4-1 captures $0 \%$

BWD $4-2$ captures $5.4 \%$

GM 38-RW3 captures $5.5 \%$

GM 38-RW1 captures $89.1 \%$
\end{abstract}

Column

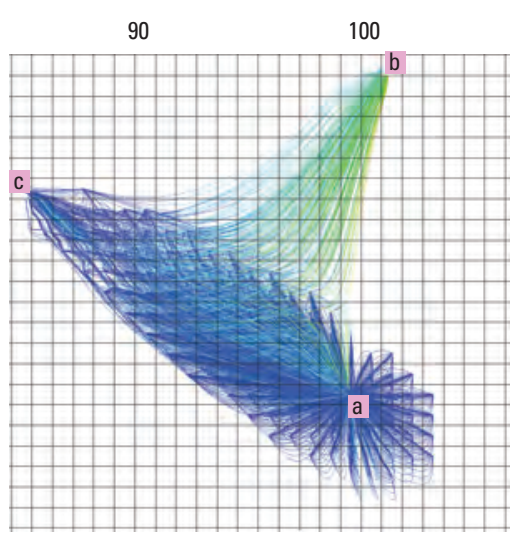

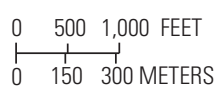

Realization B

Average travel time: 293 days

$63 \%$ have travel time < average

$1,000 \mathrm{ppb}$ plume shell (-100

to-350 ft above sea level,

ARCADIS, 2009):

BWD 4-1 captures $0 \%$

BWD 4-2 captures $5.6 \%$

GM 38-RW3 captures $5.4 \%$

GM 38-RW1 captures $89.0 \%$

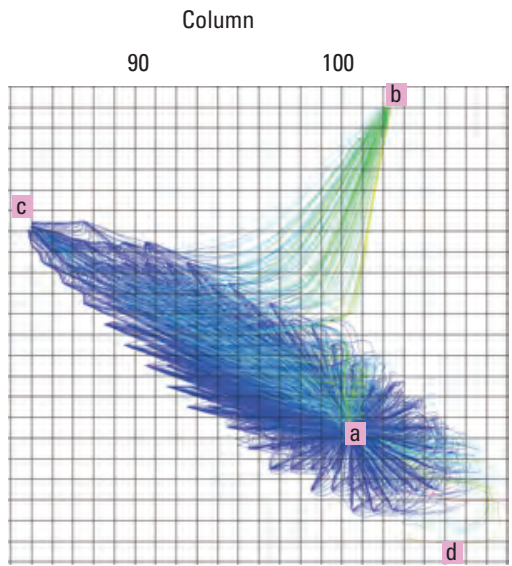

Realization C:

Average travel time: 300 days

$62 \%$ have travel time < average

$1,000 \mathrm{ppb}$ plume shell (-100

to-350 ft above sea level,

ARCADIS, 2009):

BWD 4- 1 captures $0 \%$

BWD 4-2 captures $2.7 \%$

GM 38-RW3 captures $5.0 \%$

GM 38-RW1 captures $92.3 \%$

\title{
EXPLANATION
}

\author{
a GM38-RW1 pumping well \\ b BWD-4 pumping wells \\ C GM38-RW3 pumping well \\ d Stagnation points beyond the 1,000 ppb TVOC contour (ARCADIS, 2009)
}

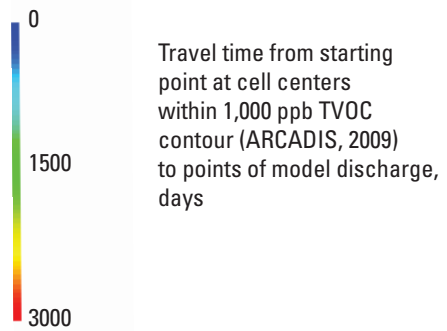

Figure 31. Travel time and pathlines of forward-tracked particles started at the inner GM-38 Hot Spot solid during present steady state conditions and Magothy aquifer heterogeneity realizations $A, B$, and C, model grid, and locations of particle discharge, Bethpage, New York. 


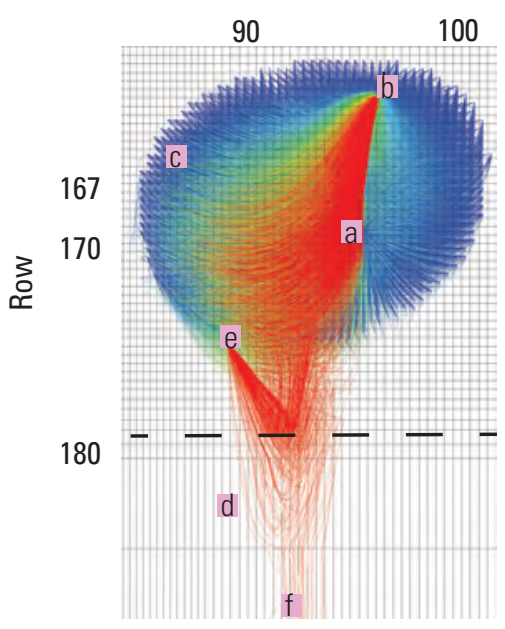

Realization A:

Average travel time: 1120 days

$78 \%$ have travel time < average

500 parts per billion plume shell (-100

to-350 ft NGVD29

TetraTech, 2002):

BWD 4-1 captures $0.0 \%$

BWD $4-2$ captures $18.3 \%$

GM 38-RW3 captures $11.4 \%$

GM 38-RW1 captures $69.4 \%$

BWD 5 captures $0.8 \%$

Constant head captures $0.0 \%$
(90

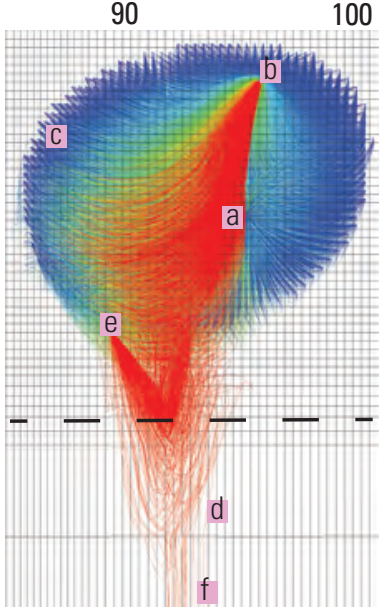

$\begin{array}{llll}0 & 250 & 500 & \text { FEET } \\ \stackrel{1}{1} & 1 & & \\ 0 & 75 & 150 & \text { METERS }\end{array}$

Realization B:

Average travel time: 1132 days

$78 \%$ have travel time < average

500 parts per billion plume shell (-100

to-350 ft NGVD29,

TetraTech, 2002):

BWD 4-1 captures $0.1 \%$

BWD $4-2$ captures $18.1 \%$

GM 38-RW3 captures $11.3 \%$

GM 38-RW1 captures $69.5 \%$

BWD 5 captures $1.0 \%$

Constant head captures $0.0 \%$
90

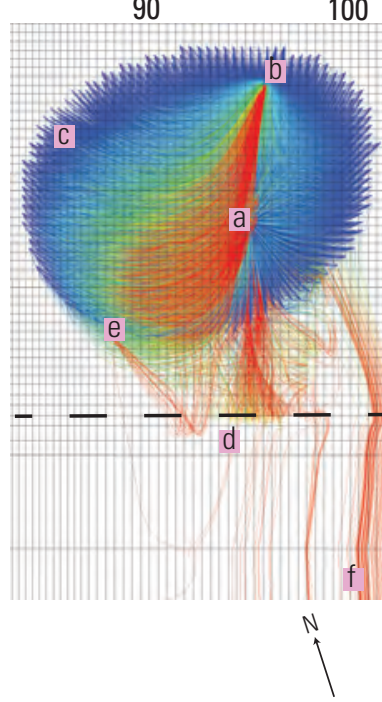

Realization C:

Average travel time: 1008 days

$76 \%$ have travel time < average

500 parts per billion plume shell (-100

to-350 ft above NGVD29

TetraTech, 2002):

BWD 4-1 captures $0.1 \%$

BWD $4-2$ captures $11.3 \%$

GM 38-RW3 captures $12.2 \%$

GM 38-RW1 captures $76.1 \%$

BWD 5 captures $0.1 \%$

Constant head captures $0.2 \%$

\section{EXPLANATION}
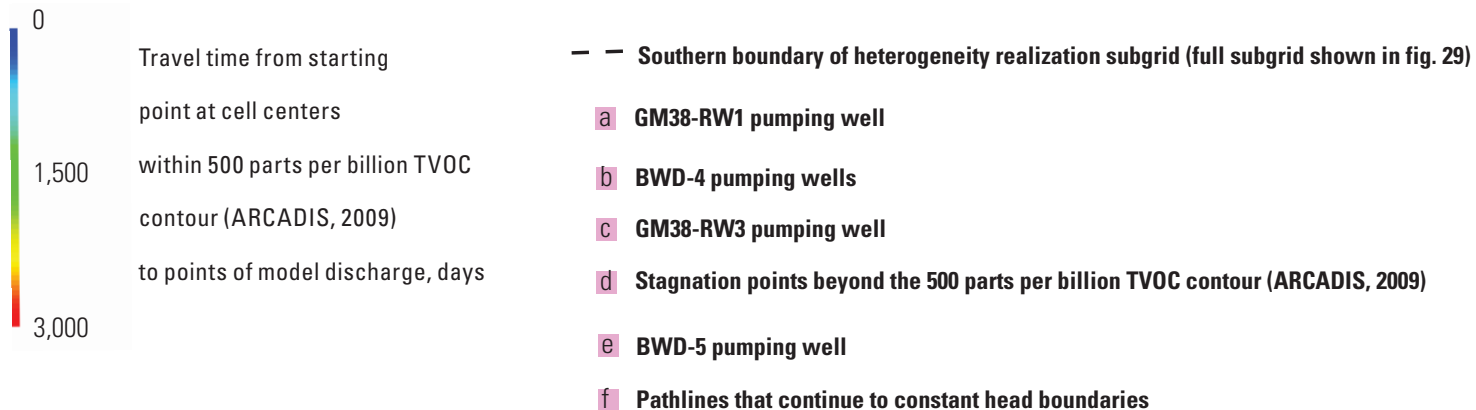

Figure 32. Travel time and pathlines of forward-tracked particles started at alternate total GM-38 Hot Spot solid during present steady state conditions and Magothy aquifer heterogeneity realizations $A, B$, and C, model grid, southern extent of heterogeneity realization subgrid, and locations of particle discharge, Bethpage, New York. 


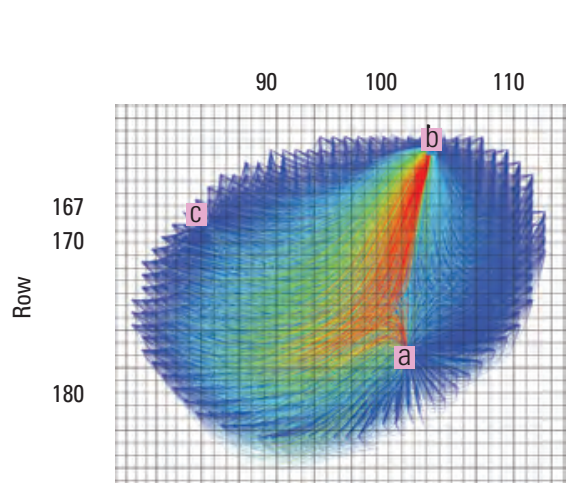

Realization A:

Average travel time: 534 days

$64 \%$ have travel time < average

1,000 parts per billion plume shell $(-100$

to-350 $\mathrm{ft}$ above sea level,

TetraTech, 2002):

BWD 4-1 captures $0.0 \%$

BWD $4-2$ captures $16.1 \%$

GM 38-RW3 captures $9.9 \%$

GM 38-RW1 captures $74.0 \%$

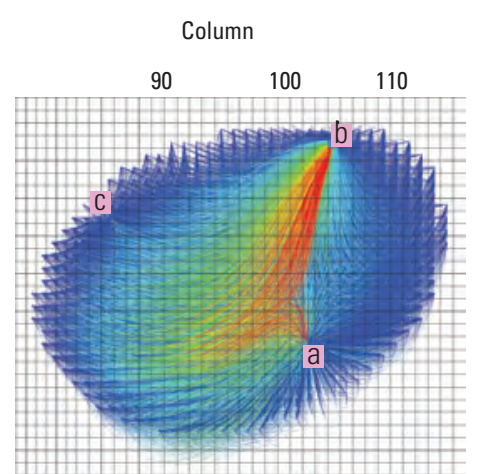

$\begin{array}{ccc}0 & 250 & 500 \text { FEET } \\ 0 & 75 & 150 \text { METERS }\end{array}$

Realization B:

Average travel time: 529 days

$64 \%$ have travel time < average

1,000 parts per billion plume shell (-100

to-350 ft above sea level,

TetraTech, 2002):

BWD 4-1 captures $0.0 \%$

BWD 4-2 captures $15.9 \%$

GM 38-RW3 captures $9.8 \%$

GM 38-RW1 captures $74.3 \%$
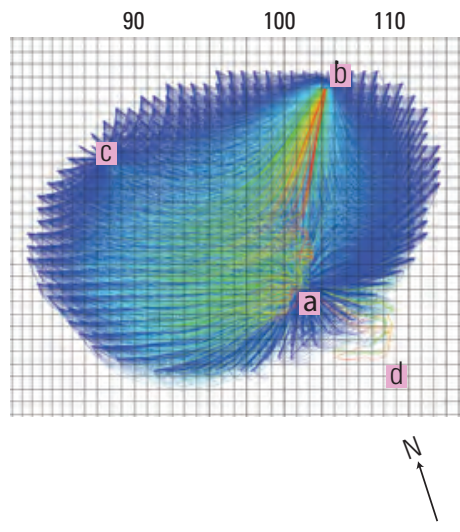

Realization C:

Average travel time: 510 days

$60 \%$ have travel time < average

1,000 parts per billion plume shell (-100

to-350 ft above sea level,

TetraTech, 2002):

BWD 4-1 captures $0.0 \%$

BWD 4-2 captures $10.6 \%$

GM 38-RW3 captures $10.1 \%$

GM 38-RW1 captures $79.3 \%$

\section{EXPLANATION}

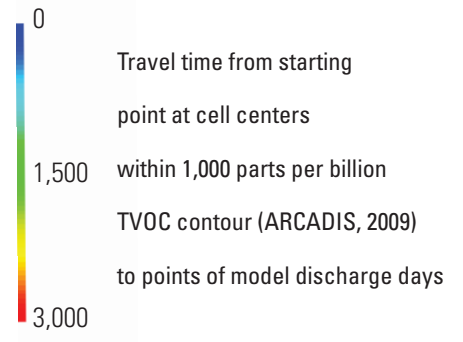

a GM38-RW1 pumping well

b BWD-4 pumping wells

C GM38-RW3 pumping well

d Stagnation points beyond the 1,000 parts per billion TVOC contour (TetraTech, 2002)

Figure 33. Travel time and pathlines of forward-tracked particles started at alternate GM-38 Hot Spot inner solid during present steady state conditions and Magothy aquifer heterogeneity realizations $A, B$, and C, model grid, and locations of particle discharge, Bethpage, New York. 
Hypothetical scenario 1 turns off the BWD4 pumping wells. These BWD wells together captured the following percentages of forward-tracked particles in present conditions steady state, started at the ARCADIS (2009) 500 ppb TVOC Hot Spot: 19.0 percent (heterogeneity realization A, fig. 30, table 10 ) and 14.4 percent (heterogeneity realization $\mathrm{C}$, fig. 30). Comparison of backward-tracked pathlines and terminations of hypothetical scenario 1 (fig. 34) with the baseline (steady state present conditions model realization A, fig. 29) indicate that when the wells at BWD4 are shut off, the GM-38 ZOC is larger and some particle pathlines shift towards the east. A greater number of particles also remain underneath the bottom plane of the Hot Spots, which are evidenced by more yellow lines continuing beyond the Hot Spot to points north in hypothetical scenario 1 (fig. 34) than in the baseline simulation (fig. 29). All of these pathways are oriented to the north-northwest in hypothetical scenario 1 (fig. 34), whereas there was a southeast-oriented pathline associated with RW1 in the baseline (fig. 29). A greater percentage of particles flow into the lower part of the GM-38-RW2 well screen without intersecting the Hot Spot solid, suggesting that the minimum pumping rate resulting in optimal capture of particles by GM-38-RW2 would likely decrease. The total number of particle terminations is greater during hypothetical scenario 1 than during the baseline, due to increased underflow; furthermore, in forward-tracking mode with the ARCADIS (2009) Hot Spot solid, all particles are captured by GM-38 wells with little stagnation beyond the solid in any heterogeneity realization. Comparison of model realizations $\mathrm{A}$ and $\mathrm{C}$ during hypothetical scenario 1 (fig. 34) indicates a slightly higher percentage of termination of RW1 particles in A than $\mathrm{C}$ and a slightly lower percentage of termination of RW2 and RW3 particles in realization A than realization $\mathrm{C}$.

Hypothetical scenarios 2 and 3 (table 12) are used to explore the effects of GM-38-RW2 pumping. RW2 has the advantage of being located close to the geographic center of the solids; however, its screen zone is deeper than the other RW wells and may tend to capture water residing beneath the bottom plane of the Hot Spot. During scenario 2, RW2 is pumped at $920 \mathrm{gal} / \mathrm{min}$ and the other GM-38-RW wells are turned off (fig. 35). Comparison of hypothetical scenario 2 pathlines (fig. 35) with baseline (fig. 29, steady state present conditions model realization A) pathlines indicate a strong hydraulic influence from RW2 pumping, with a widely distributed spread of RW2 terminations in the shape of a cone of depression and a focused stream of nonstressed RW3 pathlines beyond the 500 ppb TVOC Hot Spot. The RW3 pathlines do not terminate at a solid surface boundary because they are located in the outer solid ring upgradient from the inner solid; thus water flows toward RW3 without intersecting the inner solid and without dispersal by a hydraulic stress. During scenario 3, all three RW wells are pumped at $300 \mathrm{gal} / \mathrm{min}$. Scenario 3 increases the pumping of GM-38-RW3 from $220 \mathrm{gal} / \mathrm{min}$ during the baseline to $300 \mathrm{gal} / \mathrm{min}$. In this case there are three wide distributions of terminations associated with each of the GM-38-RW wells (fig. 35), although many particles associated with each of the wells also do not terminate, indicating significant underflow.

\section{Discussion}

To better understand factors affecting the ZOCs of GM-38 wells at Bethpage, advective particle tracking analysis was conducted in forward and backward modes. GM-38 ZOCs were delineated for present steady state and hypothetical steady state conditions. Hypothetical and alternative simulations were used to determine hydrogeologic and pumping-rate controls on the size and shape of GM-38 ZOCs. Through transitional probability analyses, the robustness of the estimates for hydraulic conductivity and, therefore ZOCs, were demonstrated in this report. Discussion topics include the ability of GM-38 wells to capture the GM-38 Hot Spot, the optimal pumping rate configuration for GM-38 wells, and modeling limitations.

\section{Capture of Contaminants}

The results of this study indicate that the majority of simulated water particles captured by the GM-38-RW wells, in either backward or forward mode, are sourced from the GM-38 Hot Spot solid, as defined by either the Tetra Tech (2002) or ARCADIS (2012) delineations of 500 or 1,000 ppb TVPOC contours. Inspection of the ZOCs of GM-38 wells indicates that the estimated 2-year ZOC (fig. 27) is roughly coincident with the size and shape of the Hot Spot and about $2,000 \mathrm{ft}$ in diameter. A 2,000-ft diameter cylinder of Magothy aquifer with porosity of 0.25 and $250-\mathrm{ft}$ thickness contains about 200 million cubic feet of water, or 1.5 billion gallons. At present, about 2 billion gallons of water have been treated by the GM-38 water treatment plant. If the Hot Spot moves purely advectively without dispersion and is not affected by other geochemical interactions, the simulations suggest that the majority of the Hot Spot TVOC mass, as defined by Tetra Tech (2002) and ARCADIS (2009), may have been captured. TVOC concentration in water pumped from GM-38 has declined significantly since the beginning of GM-38 water treatment plant operation, but it is not yet below detection (D. Brayack, TetraTech, written communication, 2013). This is likely due in part to capture of TVOC mass that is sourced from beyond the GM-38 Hot Spot.

Detailed analysis of backtracked particle pathway interception by the Hot Spot, and discharge locations of forward-tracked particles started within the Hot Spot, indicate some differences between the relative efficiencies of the GM-38 wells and also indicate that there is some particle capture by the nearby Bethpage Water District Plant 4 production wells, as well as some discharge of particles to the far southern boundaries of the groundwater-flow model. GM-38-RW1 is generally more efficient at capturing Hot 


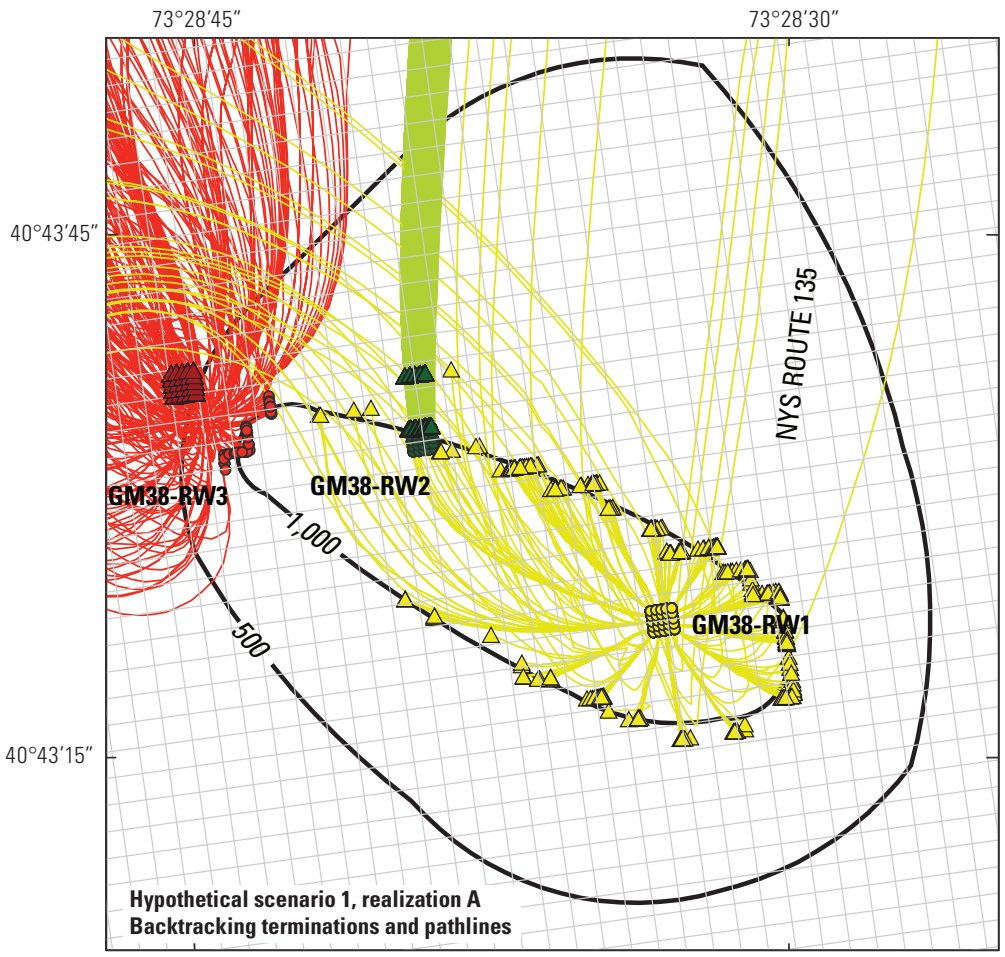

Base from U.S. Geological Survey digital data, 1:24,000

Lambert conformal conic projection, NAD83

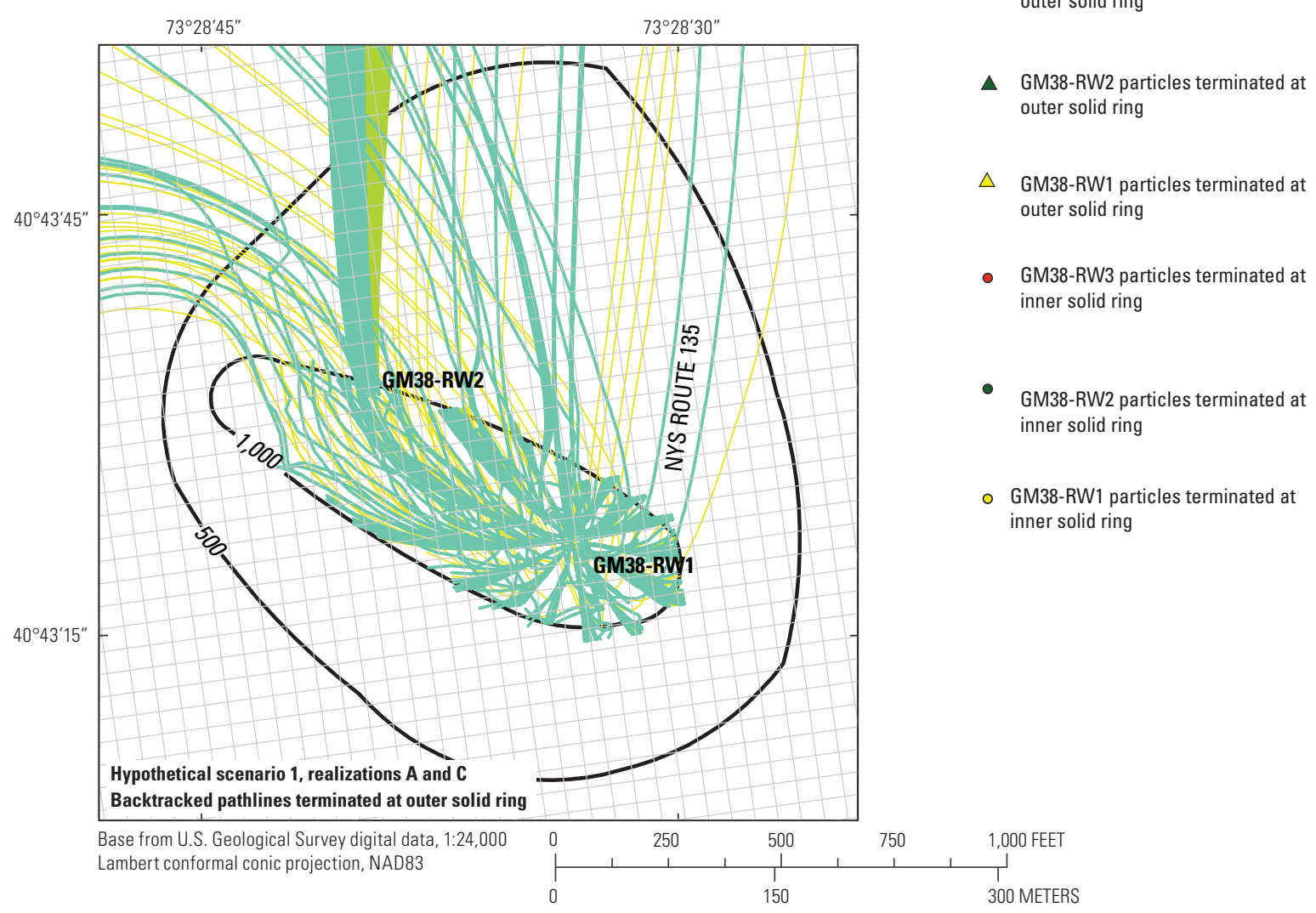

EXPLANATION

- Line of equal total volatile organic compound concentration, in micrograms per liter (ARCADIS, 2009)

Model grid

Backtracked pathlines associated with GM38-RW3, heterogeneity realization A, terminated at inner solid

Backtracked pathlines associated with GM38-RW2, heterogeneity realization A, terminated at outer solid ring

Backtracked pathlines associated with GM38-RW1 and GM38-RW2 and heterogeneity realization $A$, terminated at outer solid ring

Backtracked pathlines associated with GM38-RW1 and GM38-RW2,

heterogeneity realization C, terminated at outer solid ring

Terminations at GM38 Hot Spot Solid from (ARCADIS, 2009), Magothy aquifer Heterogeneity realization $A$

- GM38-RW3 particles terminated at outer solid ring

GM38-RW2 particles terminated at

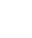

(1)


Table 12. Analysis of particle backward-tracking terminations at the GM-38 Hot Spot inner sold and outer solid rings, under three hypothetical pumping scenarios and two Magothy aquifer heterogeneity realizations ( $\mathrm{A}$ and $\mathrm{C})$, Bethpage, New York.

[gal/min, gallons per minute]

\begin{tabular}{|c|c|c|c|c|c|c|c|}
\hline \multirow[b]{2}{*}{ Hypothetical scenario } & \multicolumn{7}{|c|}{ Simulation } \\
\hline & (Baseline) & 1 & 1 & 2 & 2 & 3 & 3 \\
\hline Heterogeneity realization & A & A & C & A & C & A & C \\
\hline BWD 4 pumping & 1,600 & 0 & 0 & 1,600 & 1,600 & 1,600 & 1,600 \\
\hline \multicolumn{8}{|c|}{ Particle characteristics } \\
\hline Outer solid ring terminations & 1,170 & 706 & 690 & 715 & 684 & 813 & 765 \\
\hline GM-38-RW1 terminations at outer solid ring & 346 & 340 & 341 & 375 & 375 & 331 & 324 \\
\hline GM-38-RW2 terminations at inner solid & 736 & 250 & 250 & 340 & 309 & 250 & 318 \\
\hline GM-38-RW3 termination at inner solid & 59 & 81 & 65 & 0 & 0 & 82 & 72 \\
\hline
\end{tabular}

Spot contamination than GM-38-RW3 due to its location closer to the center of the Hot Spot. In addition, some particles move south of the Hot Spot to linger at stagnation points, yet they are ultimately captured by GM-38 wells. In addition, it appears that some backward-tracked particles move under the bottom of the Hot Spot to ultimately originate at points of water table recharge north of the NWIRP.

\section{Optimal Pumping}

Model simulations described in this report provide some direction for managing pumping rates such that excessive water is not captured by GM-38-RW wells having low TVOC concentrations. Optimization was not conducted to ensure that none of the Hot Spot escapes to other points of model discharge. If the goal of the GM-38 system is to capture the GM-38 Hot Spot, then it appears that the RW3 well is overpumping because its $\mathrm{ZOC}$ is mainly to the west and upgradient of the Hot Spot. However, the optimal pumping rate for RW3 is certainly greater than zero, with the RW3 well screen located within 1,000 ppb TVOC-contours (Tetra Tech, 2003; ARCADIS, 2009) and above the Hot Spot bottom, defined as $350 \mathrm{ft}$ below sea level. The RW2 ZOC is partially extended below the Hot Spot bottom, with the well screen 60 percent below the bottom plane $(350 \mathrm{ft}$ below sea level plane). It is clear that the hypothetical scenario 2 pumping rate (920 gal/min) is greater than optimal, because many pathlines converge into the well screen from below without crossing through the Hot Spot. Assuming these conditions, the baseline (steady state present conditions model realization $\mathrm{A}$ ) pumping rate at well GM-38-RW1 appears to be near optimal; increasing its pumping rate would likely result in entraining water with low concentrations of VOCs from below the Hot Spot, but also result in increased hydraulic influence over particles that escape to the southeast and flow towards model domain constant head boundaries. 


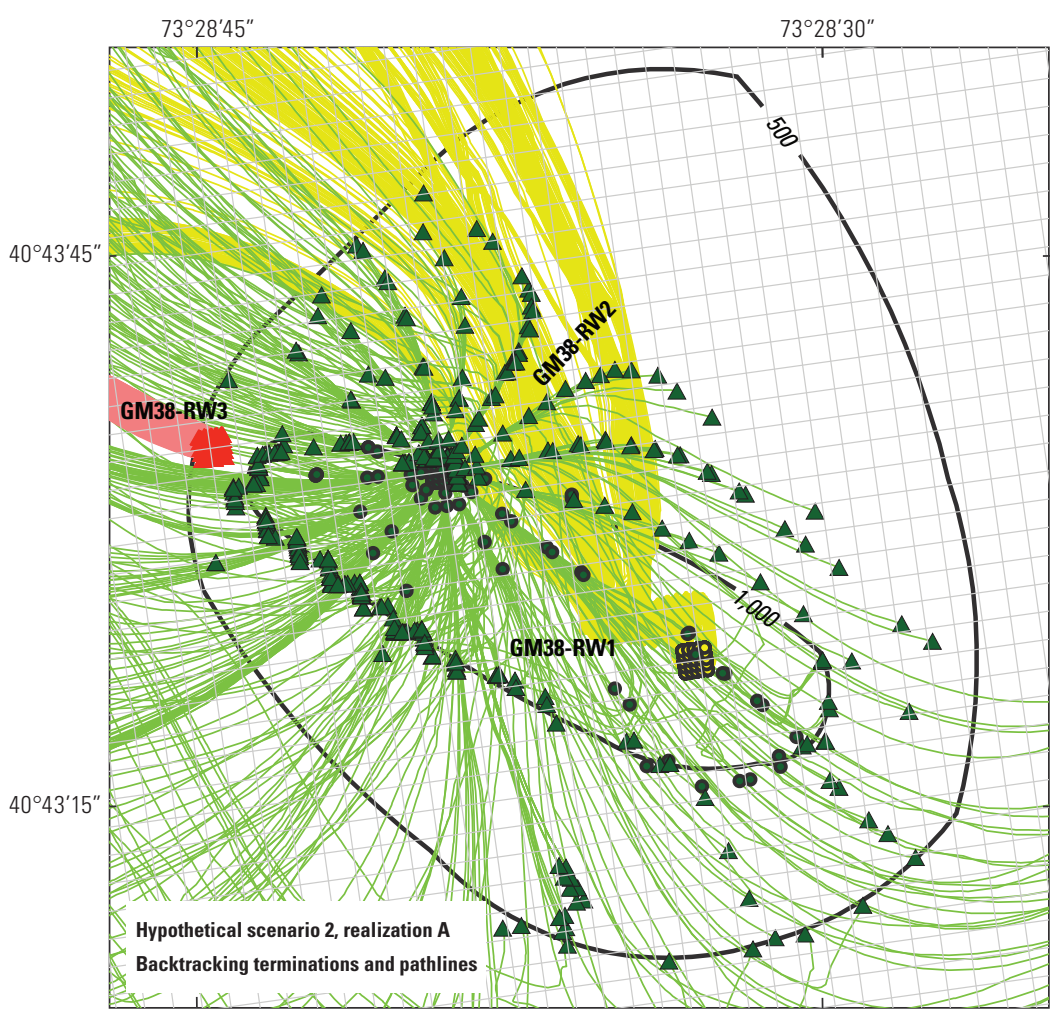

Base from U.S. Geological Survey digital data, 1:24,000

Lambert conformal conic projection, NAD83

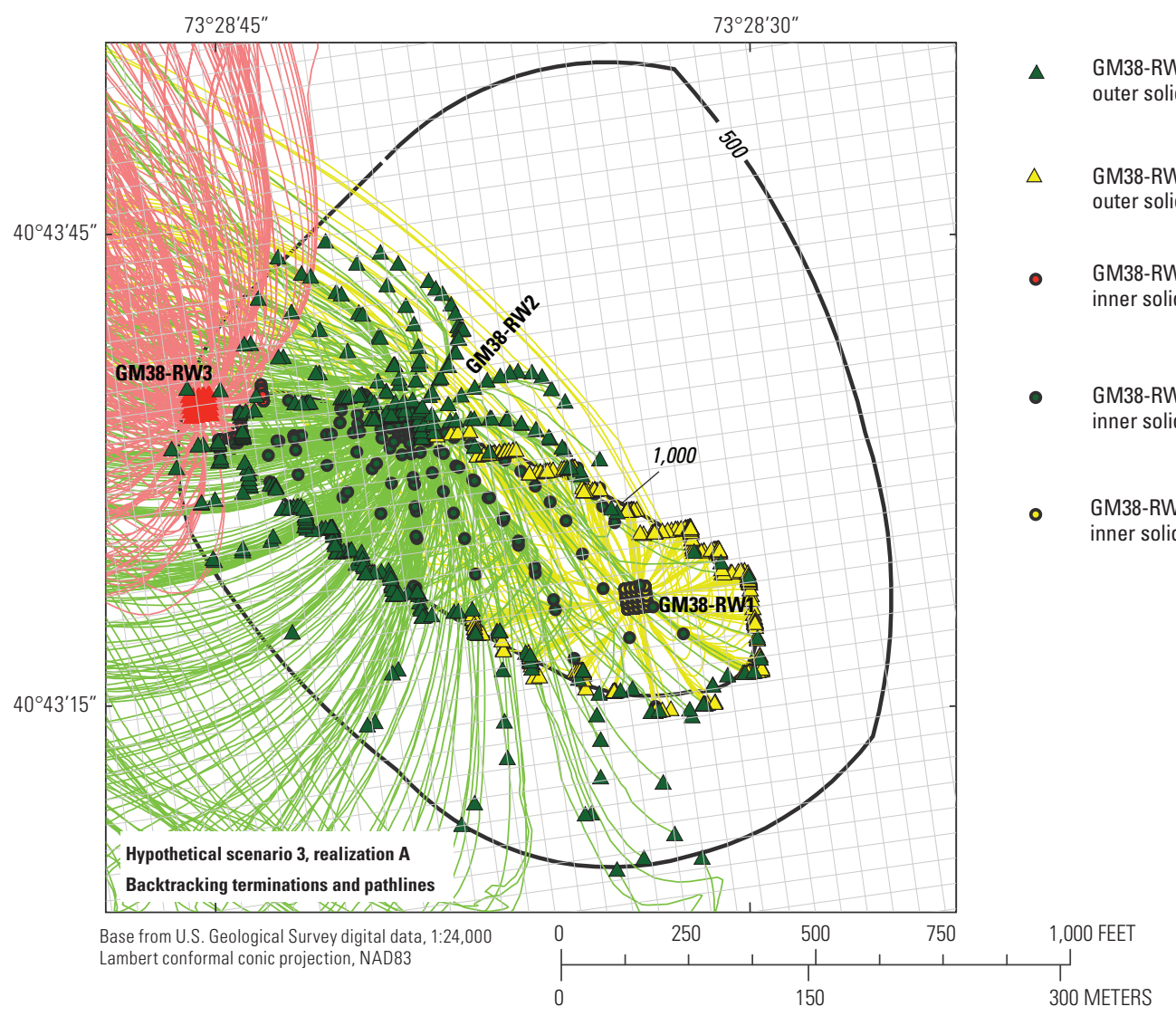

\section{EXPLANATION}

Line of equal total volatile organic compound

concentration, in parts per billion (ARCADIS, 2009)

Model grid

Backtracked pathlines associated with GM38-RW3, terminated at inner solid ring

Backtracked pathlines associated with GM38-RW2, terminated at outer solid ring

Backtracked pathlines associated with GM38-RW1, terminated at outer solid ring

Terminations at GM-38 Hot Spot Solid from (ARCADIS, 2009), Magothy aquifer Heterogeneity Realization A

- GM38-RW3 particles terminated at outer solid ring

M38-RW2 particles terminated at ter solid ring

M38-RW1 particles terminated at ter solid ring

M38-RW3 particles terminated at

M38-RW2 particles terminated at ner solid

338-RW1 particles terminated at ner solid

Figure 35. Projected pathlines captured by GM-38-RW wells and backward tracked using steady state hypothetical scenarios 2 and 3, and Magothy aquifer heterogeneity realization A, Bethpage, New York. 


\section{Limitations of Modeling}

The calibrated steady state present conditions MODFLOW model represents the groundwater system as reasonably as possible given limitations such as available computing resources, available borehole data, available water level observations, available records pertaining to hydrologic stresses, and independent estimates of model parameters. MODFLOW limitations may impact the accuracy of delineations of the zones of contribution to GM-38 pumping wells because particle tracking analyses follow flow fields simulated by MODFLOW. To evaluate the steady state assumption, an aquifer test was simulated in transient state and compared to field data. To evaluate limitations related to characterization of aquifer heterogeneity, three realizations of the hydrogeologic framework were developed using T-PROGS and a fine level of vertical MODFLOW discretization. These alternates were subjected to transient-state simulation of the aquifer test, and to particle tracking analysis of ZOCs. To evaluate the uncertainties in Hot Spot delineations, two different delineations were compared: ARCADIS (2009) and TetraTech (2002).

In addition to limitations of the MODFLOW model, there are limitations to the MODPATH particle tracking technique. Because forward- tracking and backtracking results may differ, the two are compared. The MODPATH technique is not calibrated through comparison of particle tracking results with relevant observations of the actual system, such as water quality data or changes in the plume size and shape over time. Porosity is an uncalibrated parameter and a wide range of values is given in the literature. Changes in porosity affect transient areas contributing recharge as described by Reilly and Pollock (1995), and therefore would also affect time- limited ZOC delineations, such as those shown in figure 27. If a greater porosity value is specified in the model, then particle velocities decrease, and ZOC area also decreases. Particle tracking uses advective transport only and does not account for adsorption, degradation, diffusion, and other processes that may reduce TVOC concentrations in groundwater. Additionally, ZOCs can change with hydraulic conductivity and other parameter changes. Because of the uncertainty associated with hydraulic conductivity, well hydraulics, withdrawals, flows, and recharge, estimated ZOCs should be viewed as the most likely areas and be subjected to ranges and alternate simulations. It is possible that the source loading of the GM-38 Hot Spot involves dense non-aqueous phase liquids; however, no source loading mechanisms of any type were considered in model development/calibration. It is assumed that the Hot Spot is a conservative dissolved plume of relatively low concentration (in the micrograms per liter range) that simply moves forward by groundwater flow advection from its current delineations.

ZOCs and particle pathlines are simulated with present conditions steady state models. Pathlines tracked using steady state models are similar to pathlines tracking using transient state models that represent recurring stress cycles such as seasonal recharge patterns and pumping well operations as described in Reilly and Pollock (1995); however, simulation of long term changes in model stress may result in different simulated pathlines. In this report, the use of steady state models to conduct particle tracking has been justified; however, there are likely some transient-state variations that may be represented to further improve accuracy of particle pathlines.

To balance the rates of GM-38 pumping wells, hypothetical simulations of different pumping scenarios were considered. Although a limited number of simulations resulted in a valid conclusion, increasing the number of hypothetical simulations may result in a more precise analysis of balancing options. The optimization routine GWM 2005 (Ahlfeld and others, 2009) could be used to more precisely minimize pumping and maximize plume capture.

\section{Summary and Conclusions}

Downgradient of the Naval Weapons Industrial Reserve Plant at Bethpage, New York, the GM-38 water treatment facility was installed to partially contain the GM-38 Hot Spot of dissolved volatile organic compounds (VOCs). To operate the GM-38 system effectively, the pumping of extraction wells may be balanced. In this study a numerical model was used to improve understanding of the effect of the GM-38 system on Hot Spot containment and the advective processes capturing Hot Spot VOC's. The Hot Spot was divided into two regions or volumes, the inner solid and the outer solid ring, and was delineated based on previous contouring efforts.

Model simulations were also conducted to improve understanding of how the following factors affect GM-38 zones of contribution (ZOCs): nearby pumping of BWD production wells and heterogeneity in the Magothy aquifer. Both forward- and backward-particle tracking analyses were conducted and essentially yielded the same conclusion that the GM-38 groundwater treatment plant is highly effective at capturing the GM-38 Hot Spot. The forward-tracking simulations focus on the fate of the GM-38 Hot Spot, while the backward-tracking simulations focus on particle movement processes that are affected by well hydraulic stress and how these processes relate to a detailed three-dimensional rendering of the Hot Spot volumetric solid. The percentage of backward-tracked particles, started at GM-38 wells that were sourced from within the Hot Spot, varied from 72.0 to 98.2, depending on the Hot Spot delineation used. The percentage of forward-tracked particles that were captured by GM-38 wells varied from 81.1 to 94.6, depending on the Hot Spot delineation used, with the remainder primarily captured by Bethpage Water District Plant 4 production wells. Less than 1 percent of forward-tracked particles ultimately discharge at model constant head and drain boundaries. The differences between percentage ranges is due to some forward-tracked particles not being captured by GM-38 wells, and some 
backward-tracked particles not intersecting specific regions of the Hot Spot.

Because the model is very much a simplification of the real conditions and because values of important physical controlling parameters are to a large extent uncertain, this analysis considers variations of both parameter values and hydrologic conditions, in order to bracket important factors that control GM-38 ZOCs. By use of borehole logs, a transitional probability approach generated alternate representations of heterogeneity within the Magothy aquifer. Low hydraulic conductivity fine-grained sediments were laterally discontinuous, thickening towards the south, and found to statistically comprise about 17 percent of the total aquifer volume realized in the area of interest surrounding the GM-38 Hot Spot. Through transitional probability analyses, the robustness of the estimates for hydraulic conductivity and, therefore ZOCs, were demonstrated.

\section{References Cited}

Ahlfeld, D.P., Baker, K.M., and Barlow, P.M., 2009, GWM-2005-A Groundwater-Management Process for MODFLOW-2005 with Local Grid Refinement (LGR) capability: U.S. Geological Survey Techniques and Methods book6, chap. A33, $65 \mathrm{p}$

ARCADIS, 2003, Comprehensive groundwater model report: U.S. Naval Weapons Industrial Reserve Plant/Northrup Grumman, April 28, 2003.

ARCADIS, 2009, Remedial investigation report (study area groundwater), Operable Unit 3 (former Grumman Settling Ponds), Bethpage, New York: Melville, N.Y., 111 p. plus 3 appendixes.

ARCADIS, 2010, DRAFT Comprehensive feasibility study, volume 2-Study area Operable Unit 3 (Former Grumman Settling Ponds), Bethpage, New York, NYSDEC Site \# 1-30-003A2010.

ARCADIS, 2011, Annual groundwater monitoring report, Operable Unit 2, Bethpage, New York, NYSDEC Site \# $1-30-003$ A2010.

Busciolano, R., 2005, Statistical analysis of long-term hydrologic records for selection of drought-monitoring sites on Long Island, New York: U.S. Geological Survey Scientific Investigations Report 2005-5152, 14 p.

Buxton, H.T., and Smolensky, D.A., 1999, Simulation of the effects of the groundwater flow system of Long Island, New York: U.S. Geological Survey Water-Resources Investigations Report 98-4069, 57 p.

Carle, S.F. 1999, T-PROGS: Transition Probability Geostatistical Software, version 2.1: University of California, Davis, 77 p.
Franke, O. L., Reilly, T. E., Pollock, D. W., and LaBaugh, J. W., 1998, Estimating areas contributing recharge to wellLessons from previous studies: U.S. Geological Survey Circular 1174, $14 \mathrm{p}$.

Getzen, R.T., 1977, Analog-model analysis of regional threedimensional flow in the ground-water reservoir of Long Island, New York: U.S. Geological Survey Professional Paper 982, 49 p.

Harbaugh, A.W., 2005, MODFLOW-2005, the U.S. Geological Survey modular ground-water model -the ground-water flow process: U.S. Geological Survey Techniques and Methods book 6, chap. A16, variously paginated.

Konikow, L.F., Hornberger, G.Z., Halford, K.J., and Hanson, R.T., 2009, Revised multi-node well (MNW2) package for MODFLOW ground-water flow model: U.S. Geological Survey Techniques and Methods book 6, chap. A30, 67 p.

McClymonds, N.E., and Franke, O.L., 1972, Watertransmitting properties of aquifers on Long Island, New York: U.S. Geological Survey Professional Paper 627-E, $24 \mathrm{p}$.

McDonald, M.G., and Harbaugh, A.W., 1988, A modular three-dimensional finite-difference ground-water flow model: U.S. Geological Survey Techniques of WaterResources Investigations, book 6, chap. A1, 586 p.

Miller, J.F, and Frederick, R.H., 1969, The precipitation regime of Long Island, N.Y.: U.S. Geological Survey Professional Paper 627-A, 21 p.

Misut, P.E., 2011, Simulation of groundwater flow in a volatile organic compound-contaminated area near Bethpage, Nassau County, New York-A discussion of modeling considerations. U.S. Geological Survey Open-File Report 2011-1128, 19 p., http://pubs.usgs.gov/of/2011/1128/.

Misut, P.E., and Aphale, O., 2014, Simulation of groundwater pathlines and freshwater/saltwater transition zone movement, Manhasset Neck, Nassau County, New York: U.S. Geological Survey Scientific Investigations Report 2013-5201, 44 p.

Misut, P.E., and Busciolano, R.J., 2009, Hydraulic properties of the Magothy and Upper Glacial aquifers at Centereach, Suffolk County, New York: U.S. Geological Survey Scientific Investigations Report 2009-5190, 23 p., http:// pubs.usgs.gov/sir/2009/5190.

Misut, P.E., and Feldman, S.M., 1996, Delineation of areas contributing recharge to wells in central Long Island, New York by particle tracking: U.S. Geological Survey OpenFile Report 95-703, 47 p. 
Monti, Jack, Jr., and Busciolano, R., 2009, Water-table and potentiometric-surface altitudes in the Upper Glacial, Magothy, and Lloyd aquifers beneath Long Island, New York, March-April 2006: U.S. Geological Survey Scientific Investigations Map 3066, 4 sheets.

Monti, Jack, Jr., Como, Michael, and Busciolano, Ronald, 2013, Water-table and potentiometric-surface altitudes in the Upper Glacial, Magothy, and Lloyd aquifers beneath Long Island, New York, April-May 2010: U.S. Geological Survey, Scientific Investigations Map 3270, 4 sheets, scale 1:125,000.

Morrissey, D.J., 1989, Estimation of the recharge area contributing water to a pumped well in a glacial-drift, rivervalley aquifer: U.S Geological Survey Water-Supply Paper 2338, $41 \mathrm{p}$.

Nassau County Department of Public Works, 2009, Nassau County Storm Water Management Program Plan, 34 p.

New York State Department of Environmental Conservation (NYSDEC), 2013, Remedial Investigation Work Plan: Bethpage Community Park Ice Rink Area, Site No. C130212, November, 2013: $177 \mathrm{p}$.

New York State Orthoimagery Program, 2010, 2010 imagery in Nassau County: Albany, New York State Office of Cyber Security.

Poeter, E.P., Hill, M.C., Banta, E.R., Mehl, Steffen, and Christensen, Steen, 2005, UCODE_2005 and six other computer codes for universal sensitivity analysis, calibration, and uncertainty evaluation: U.S. Geological Survey Techniques and Methods book 6, chap. A11, 283 p.

Pollock, D.W., 2012, User guide for MODPATH version 6-A particle-tracking model for MODFLOW: U.S. Geological Survey Techniques and Methods, book 6, chap. A41, 58 p.

Reilly, T.E., and Pollock, D.W., 1993, Factors affecting areas contributing recharge to wells in shallow aquifers: U.S. Geological Survey Water-Supply Paper 2412, 21 p.

Reilly, T.E., and Pollock, D.W., 1995, Effect of seasonal and long-term changes in stress on sources of water to wells: U.S. Geological Survey Water-Supply Paper 2445, 25 p.

Rozell, D. 2010, Urbanization and trends in Long Island stream base flow, Long Island Geologists Conference, SUNY Stony Brook April 15, 2010.

Seaburn, G.E. and D.A. Aronson, 1974, Influence of recharge basins on the hydrology on Nassau and Suffolk Counties, Long Island, New York: U.S. Geological Survey WaterSupply Paper 2031, 66 p.

Smolensky, D.A., Buxton, H.T., and Shernoff, P.T., 1989, Hydrogeologic framework of Long Island, New York: U.S. Geological Survey Hydrologic Investigations Atlas, 3 sheets, scale 1:250,000.
Smolenksy, D.A., and Feldman, S.M., 1995, Threedimensional advection transport of volatile organic compounds in ground water beneath an industrial/residential area of Nassau County, New York: U.S. Geological Survey Water-Resources Investigations Report 92-4148, 53 p.

Tetra Tech, 2002, Conceptual design report for GM-38 Area groundwater, Naval Weapons Industrial Reserve Plant (NWIRP), Bethpage, New York.

Tetra Tech, 2012a, Study of alternatives for management of impacted groundwater at Bethpage: Evaluation of remedial alternatives for the Bethpage Plume under Contract Task Order (CTO) WE06 for NAVFAC Mid-Atlantic under the Comprehensive Long-Term Environmental Action Navy (CLEAN) contract number N62470-08-D-1001.

Tetra Tech, 2012b, Letter Work Plan: Water level and pumping test activities to support GM-38 capture zone analysis: Naval Weapons Industrial Reserve Plant, Bethpage, New York.

Tetra Tech, 2013, Technical memorandum: Aquifer test analysis. Bethpage, New York, June 20, 2013.

U.S. Geological Survey (USGS), 1996, Office of Ground Water Technical Memorandum No. 96.04: "PublicationsPolicy on documenting the use of ground-water simulation in project reports: http://water.usgs.gov/admin/memo/GW/ gw96.04.html.

U.S. Geological Survey (USGS), 2003, Office of Ground Water Technical Memorandum No. 2003.02: Subject: Terminology used in studies of the source of water to wells under steady-state conditions: http://water.usgs.gov/admin/ memo/GW/gw03.02.html.

U.S. Navy, 2003, Engineering field activity, Northeast Naval Facilities Engineering Command. Record of Decision Naval Weapons Industrial Reserve Plant Bethpage, New York Operable Unit 2-Groundwater: New York State Registry: 1-30-003B, April (revision 1).

Winston, R.B., 2009, ModelMuse-A graphical user interface for MODFLOW-2005 and PHAST: U.S. Geological Survey Techniques and Methods book 6, chap. A29, 52 p

Zheng, C., 1990, MT3D, a modular three-dimensional transport model for simulation of advection, dispersion and chemical reactions of contaminants in groundwater systems: Report to the U.S. Environmental Protection Agency, 170 p. 


\section{Glossary and Abbreviations}

Specialized technical terms and abbreviations used in this report are defined below. Definitions pertaining to regulation are taken from http://www.nysdec.gov and http://www.epa.gov.

\section{A}

Advection A transport mechanism of a substance by a fluid due to the fluid's bulk motion in a particular direction.

Anisotropy The property of being directionally dependent, as opposed to isotropy, which implies identical properties in all directions. An example of an anisotropic material is wood, which is easier to split along its grain than against it.

Area contributing recharge The surface area on the boundary of the groundwater system that delineates the location of the water entering the groundwater system that eventually flows to the well.

\section{B}

BPOW Bethpage observation well.

BWD Bethpage Water District.

\section{C}

Composite Scaled Sensitivity (CSS) Composite scaled sensitivities indicate the information content of all the observations for the estimation of a parameter.

Cone of depression Conical-shaped depression of head or water level surrounding a pumped well.

Confining unit A layer of geologic material that impedes the movement of water into and (or) out of an aquifer.

\section{D}

Diffusion The spread of particles through random motion from regions of higher concentration to regions of lower concentration.

\section{G}

GM Gerraghty and Miller, a consultant to Northrop Grumman Corporation, which named sites within the Bethpage area.

\section{H}

Hard data A term that is used in the T-PROGs literature to describe data that are not subject to modification, but are fixed at initial values. The model realizes the framework geometry around the hard data but not at the hard data. It is important to emphasize that hard data are honored. The soft data are the realization, which forms an input dataset for MODFLOW.

Heterogeneity Lack of uniformity in composition or character.

Homogeneous Uniform in composition or character.
Hot spot A small area of intense or important activity embedded in a larger area of relative calm. In this study, the GM-38 Hot Spot refers to a TVOC plume shell located near GM-38 pumping wells.

I

Interim remedial measure (IRM) An interim remedial measure is a discrete set of activities to address both emergency and nonemergency site conditions, which can be undertaken without extensive investigation and evaluation, to prevent, mitigate, or remedy human exposure and (or) environmental damage or the consequences of human exposure and (or) environmental damage attributable to a site.

L

Least squares minimization The best fit in the least-squares; minimizes the sum of squared residuals, a residual being the difference between an observed value and the fitted value provided by a model.

Lloyd aquifer The Lloyd aquifer is the deepest and oldest of Long Island's aquifers, composed of fine to coarse sand and gravel with a clayey matrix and some layers of silty or solid clay. The aquifer was derived from stream erosion of areas to the north and west during the late Cretaceous age.

M

Magothy aquifer The largest of Long Island's aquifers, composed of river delta sediments that were deposited on top of the Raritan Formation during the late Cretaceous age . Fine to medium sand is interbedded with clay and sandy clay of moderate permeability and silt and clay of low to very low permeability. The basal zone commonly contains coarse sand and gravel.

MODFLOW U.S. Geological Survey groundwater-flow modeling software.

MODPATH U.S. Geological Survey particle tracking analysis software.

Monitoring wells (MW) Wells (often small-diameter wells) drilled for measuring water levels and testing water quality. Monitoring wells are not typically used to supply water.

MT3D Solute transport modeling software developed at University of Alabama.

$\mathbf{N}$

NCDH Nassau County Department of Health.

NYSDEC New York State Department of Environmental Conservation.

NWIRP Naval Weapons Industrial Reserve Plant.

0

ONCT Onsite containment system, used to prevent contaminants from migrating offsite. 
Operable unit (OU) An operable unit addresses geographical portions of a site, specific site problems, or initial phases of an action, or may consist of any set of actions performed over time or any actions that are concurrent but located in different parts of a site.

\section{$P$}

Particle tracking analysis Water particles tracked through time assuming they are transported by advection using a simulated flow field. Particles can be tracked either forward in time or backward in time. This qualitative approach does not conserve mass.

Plume A body of contaminated groundwater flowing from a specific source. The movement of the groundwater is influenced by such factors as local groundwater-flow patterns, the character of the aquifer in which groundwater is contained, and the density of contaminants.

Porosity A measure of the void spaces in a material; also a fraction of the volume of voids over the total volume, between $0-1$, or as a percentage between $0-100$ percent.

ppb Parts per billion.

\section{R}

Raritan confining unit Underlies the Magothy aquifer, derived from stream erosion of areas to the north and west during the late Cretaceous age.

Record of decision A public document that explains which cleanup alternatives will be used to clean a contaminated site.

Remedial investigation An investigation to determine the nature and extent of contamination, assess the treatability of site contamination, and evaluate the potential performance and cost of treatment technologies.

Residual The error in a result.

Robustness The ability of system to resist change without adapting its initial stable configuration.

\section{S}

Sensitivity analysis A technique for systematically changing parameters in a model to determine the relative effects of such changes.

SPDES State Pollution Discharge Elimination System.
Specific storage The amount of water that a portion of an aquifer releases from storage, per unit mass or volume of aquifer, per unit change in hydraulic head, while remaining fully saturated.

Steady state A system is in steady state if its behavior is unchanging.

SFWD South Farmingdale Water District.

$\mathbf{T}$

T-PROGS Transitional probability

geostatistical software.

TVOC Total volatile organic compounds (VOCs).

\section{U}

Upper glacial aquifer An unconfined aquifer directly underlying the Long Island ground surface. The upper glacial aquifer was formed during the last ice age.

UCODE_2005 U.S. Geological Survey universal inverse modeling software.

V

VOC Volatile organic compound.

VPB Vertical profile borings.

W

Water table The top of an unconfined aquifer below which the pore spaces are generally saturated; the level in the saturated zone.

\section{Z}

ZOC Zone of contribution, the threedimensional volumetric part of an aquifer through which groundwater flows to a well from the area contributing recharge. 
Appendix 1. List of wells with New York State Department of Environmental Conservation (NYSDEC) and U.S. Geological Survey (USGS) identification numbers.

\begin{tabular}{|c|c|c|}
\hline $\begin{array}{c}\text { Local } \\
\text { well number }\end{array}$ & $\begin{array}{c}\text { NYSDEC } \\
\text { well number }\end{array}$ & $\begin{array}{c}\text { USGS } \\
\text { well number }\end{array}$ \\
\hline MW111 & N6781 & 404434073285301 \\
\hline BPOW 1-1 & & [Observation well not in USGS database] \\
\hline SFWD 4043 & N4043 & 404307073275101 \\
\hline SFWD 7377 & N7377 & 404312073274801 \\
\hline BWD 5-1 & N8004 & 404343073284301 \\
\hline BWD 4-1 & N6915 & 404400073283201 \\
\hline BWD 4-2 & N6916 & 404358073283102 \\
\hline BWD 6-1 & N6915 & 404400073283201 \\
\hline BWD 6-2 & N6916 & 404358073283102 \\
\hline GM 38-RW1 & & [Navy production well not in USGS database] \\
\hline \multirow[t]{9}{*}{ GM 38-RW3 } & & [Navy production well not in USGS database] \\
\hline & N10597 & 404451073302201 \\
\hline & N10600 & 404424073300101 \\
\hline & N10627 & 404415073294501 \\
\hline & N10631 & 404427072294701 \\
\hline & N10633 & 404422073291901 \\
\hline & N10634 & 404413073292801 \\
\hline & N10821 & 404517073290201 \\
\hline & N9929 & 404340073283901 \\
\hline GM 13D & & [Observation well not in USGS database] \\
\hline GM 15-1 & N10626 & 404435073291401 \\
\hline GM 15-2 & & [Observation well not in USGS database] \\
\hline GM 15-3 & & [Observation well not in USGS database] \\
\hline GM 15-4 & & [Observation well not in USGS database] \\
\hline GM 17-1 & & [Observation well not in USGS database] \\
\hline GM 17-2 & & [Observation well not in USGS database] \\
\hline GM 17-3 & & [Observation well not in USGS database] \\
\hline GM $18-1$ & N10599 & 404428073294701 \\
\hline GM 18-2 & & [Observation well not in USGS database] \\
\hline GM 18-3 & & [Observation well not in USGS database] \\
\hline GM 19-1 & & [Observation well not in USGS database] \\
\hline GM 19-2 & & [Observation well not in USGS database] \\
\hline GM 20-1 & N10632 & 404425073293601 \\
\hline GM 20-2 & & [Observation well not in USGS database] \\
\hline
\end{tabular}


Appendix 1. List of wells with New York State Department of Environmental Conservation (NYSDEC) and U.S. Geological Survey (USGS) identification numbers.

\begin{tabular}{|c|c|c|}
\hline $\begin{array}{l}\text { Local } \\
\text { well number }\end{array}$ & $\begin{array}{c}\text { NYSDEC } \\
\text { well number }\end{array}$ & $\begin{array}{c}\text { USGS } \\
\text { well number }\end{array}$ \\
\hline GM 21-2 & N10601 & 404425073293301 \\
\hline GM 33 & & [Observation well not in USGS database] \\
\hline GM 34-1 & N10998 & 404354073294504 \\
\hline GM 34-2 & N10997 & 404354073294503 \\
\hline GM 35 & & [Observation well not in USGS database] \\
\hline GM 36-1 & & [Observation well not in USGS database] \\
\hline GM 36-2 & & [Observation well not in USGS database] \\
\hline GM 37-1 & & [Observation well not in USGS database] \\
\hline GM 38-1 & & [Observation well not in USGS database] \\
\hline GM 38-2 & & [Observation well not in USGS database] \\
\hline GM 70 & & [Observation well not in USGS database] \\
\hline GM 71 & & [Observation well not in USGS database] \\
\hline GM 73-2 & & [Observation well not in USGS database] \\
\hline GM 74-1 & & [Observation well not in USGS database] \\
\hline GM 74-2 & & [Observation well not in USGS database] \\
\hline GM 74-3 & & [Observation well not in USGS database] \\
\hline GM 75 & & [Observation well not in USGS database] \\
\hline GM 78-1 & & [Observation well not in USGS database] \\
\hline GM 78-2 & & [Observation well not in USGS database] \\
\hline GM 79-1 & & [Observation well not in USGS database] \\
\hline GM 79-2 & & [Observation well not in USGS database] \\
\hline GM 79-3 & & [Observation well not in USGS database] \\
\hline GM 16-1 & & [Observation well not in USGS database] \\
\hline \multirow[t]{10}{*}{ GM 16-2 } & & [Observation well not in USGS database] \\
\hline & N1232 & 404542073282803 \\
\hline & N1234 & 404418073281401 \\
\hline & N1236 & 404301073275201 \\
\hline & N8669 & 404144073285201 \\
\hline & N8888 & 404702073305601 \\
\hline & N9079 & 404504073302002 \\
\hline & N9088 & 404413073282303 \\
\hline & N9089 & 404740073285701 \\
\hline & N9471 & 404129073290601 \\
\hline
\end{tabular}


Appendix 1. List of wells with New York State Department of Environmental Conservation (NYSDEC) and U.S. Geological Survey (USGS) identification numbers.

\begin{tabular}{lcc}
\hline $\begin{array}{c}\text { Local } \\
\text { well number }\end{array}$ & $\begin{array}{c}\text { NYSDEC } \\
\text { well number }\end{array}$ & $\begin{array}{c}\text { USGS } \\
\text { well number }\end{array}$ \\
\hline N9658 & 404219073293402 \\
\hline N9660 & 404228073274101 \\
\hline N9661 & 404338073280501 \\
\hline N9664 & 404136073303801 \\
\hline N9918 & 404435073305701 \\
\hline N9920 & 404607073302101 \\
\hline N9921 & 404418073294401 \\
\hline N9924 & 404320073305601 \\
\hline N9927 & 404631073311801 \\
\hline N9928 & 404624073321501 \\
\hline N9931 & 404502073291701 \\
\hline N9932 & 404603073292001 \\
\hline N9935 & 404622073273201 \\
\hline N9936 & 404458073270101 \\
\hline N9981 & 404642073295601 \\
\hline N11067 & {$[$ Observation well not in USGS database $]$} \\
\hline & 404636073271001 \\
\hline & 404303073295501 \\
\hline & 404317073291105 \\
\hline
\end{tabular}


Prepared by the Pembroke Publishing Service Center

For additional information write to:

New York Water Science Center

U.S. Geological Survey

2045 Route 112, Bldg. 4

Coram, NY 11727

Information requests:

(518) 285-5602

or visit our Web site at: http://ny.water.usgs.gov 
